\title{
Response Characteristics of Selected Personnel Neutron Dosimeters
}
J. C. McDonald
P. L. Roberson
J. J. Fix
G. W. R. Endres
R. T. Hadley
L. L. Nichols
K. L. Holbrook
R. B. Schwartz
R. C. Yoder

September 1983

Prepared for the U.S. Department of Energy under Contract DE-AC06-76RLO 1830

Pacific Northwest Laboratory Operated for the U.S. Department of Energy by Battelle Memorial Institute 


\title{
DISCLAIMER
}

This report was prepared as an account of work sponsored by an agency of the United States Government. Neither the United States Government nor any agency thereof, nor any of their employees, makes any warranty, express or implied, or assumes any legal liability or responsibility for the accuracy, completeness, or usefulness of any information, apparatus, product, or process disclosed, or represents that its use would not infringe privately owned rights. Reference herein to any specific commercial product, process, or service by trade name, trademark, manufacturer, or otherwise, does not necessarily constitute or imply its endorsement, recommendation, or favoring by the United States Government or any agency thereof. The views and opinions of authors expressed herein do not necessarily state or reflect those of the United States Government or any agency thereof.

\author{
PACIFIC NORTHWEST LABORATORY \\ operated by \\ BATTELLE \\ for the \\ UNITED STATES DEPARTMENT OF ENERGY \\ under Contract DE-AC06-76RLO 1830
}

\begin{tabular}{|c|c|}
\hline \multicolumn{2}{|c|}{$\begin{array}{l}\text { Printed in the United States of America } \\
\text { Available from } \\
\text { National Technical Information Service } \\
\text { United States Department of Commerce } \\
5285 \text { Port Rayal Road } \\
\text { Springfield, Virginia } 22161\end{array}$} \\
\hline \multicolumn{2}{|c|}{$\begin{array}{l}\text { NFIS Price Codes } \\
\text { Microfiche A01 }\end{array}$} \\
\hline \multicolumn{2}{|c|}{ Printed Copy } \\
\hline Pages & $\begin{array}{l}\text { Price } \\
\text { Codes }\end{array}$ \\
\hline $001-025$ & $\mathrm{~A} 02$ \\
\hline $026-050$ & $\mathrm{~A} 03$ \\
\hline $051-075$ & A04 \\
\hline $076-100$ & A05 \\
\hline $101-125$ & $A 06$ \\
\hline $126-150$ & $A 07$ \\
\hline $151-175$ & $\mathrm{~A} 0 \mathrm{~B}$ \\
\hline $176-200$ & A09 \\
\hline $201-225$ & A010 \\
\hline $226-250$ & A011 \\
\hline $251-275$ & $A 012$ \\
\hline $276-300$ & A013 \\
\hline
\end{tabular}


RESPONSE CHARACTERISTICS OF SELECTED

PERSONNEL NEUTRON DOSIMETERS
J. C. McDonald
J. J. Fix
R. T. Hadley
K. L. Holbrogk (a)
R. C. Yoder
P. L. Roberson
G. W. R. Endres
L. L. Nichols
R. B. Schwartz (b)

September 1983

Prepared for the

U.S. Department of Energy

under Contract DE-AC06-76RL0 1830

Pacific Northwest Laboratory

Richland, Washington 99352

(a) University of Texas Hospital Galveston, TX 77550

(b) R. S. Landuer, Jr., \& Company Glenwood Science Park Glenwood, IL 60425

(b) National Bureau of Standards U.S. Department of Commerce Washington, DC 20234 


\section{FOREWORD}

Response characteristics of selected personnel neutron dosimeters in current use at Department of Energy (DOE) facilities were determined as part of the DOE Personnel Neutron Dosimeter Upgrade Program. This determination is important to achieving the overall objectives of the program for several reasons, including:

- providing a uniform assessment of performance characteristics for personnel neutron dosimeters in routine use by several DOE laboratories

- measuring the accuracy and reproducibility of personnel neutron dosimeter dose evaluations in known radiation fields

- establishing a basis for comparison of prototype personnel neutron dosimeters currently under development

- comparing current personnel neutron dosimetry performance with existing and proposed dose limits

- identifying any current personnel neutron dosimeter concepts which are superior in performance.

It is important to point out at the outset that the data contained herein may not be totally indicative of the accuracy of occupational doses determined routinely by the respective laboratories. Several laboratories utilize supporting field instrument data, such as measurements using rem meters, tissue equivalent proportional counters, and/or 3 -inch and 9-inch sphere measurements, in evaluating the occupational dose received. In addition, all results herein are strictly blind in that no laboratory's data are explicitly identified. 


\section{EXECUTIVE SUMMARY}

A series of personnel dosimeter neutron irradiations was carried out to determine certain performance characteristics of selected personnel neutron dosimeters that are in current use at Department of Energy (DOE) facilities. These irradiations were quite specialized since they employed only well defined beams and a few highly standardized neutron sources. Information obtained was not intended to directly evaluate any participating laboratory's ability to determine occupational dose. Many laboratories utilize additional information such as field measurements of neutron dose and spectra to arrive at actual personnel doses. Since the neutron sources were so highly standardized, they could be used to determine the inherent accuracy and precision, along with the lower detection limit and energy dependence of each type of dosimeter.

This program was designed to provide a consistent evaluation of certain common characteristics of the different dosimeters in use by exposing all the types employed in this study to the same radiation fields. The processing and read-out of the dosimeters was carried out by the participating laboratories.

The results of this study form a useful data base which should provide valuable information to the participants. They may determine their performance relative to the range of other participants from the information in this report. This information is available to the participants, although the results are presented in this report in a strictly blind manner. In addition, since there were some neutron fields used in this study which may not have been previously encountered by the participants, they may determine their energy dependent corrections for these fields relative to the calibration neutron field of unmoderated ${ }^{252} \mathrm{Cf}$.

The findings of this study are described in detail in the text and in Appendix A. Only the highlights are given here. First, as to the accuracy as determined by these tests, it was found that when all of the laboratories employed a common set of calibrations, the overall accuracy was approximately $\pm 20 \%$, which is within uncertainty expected for these dosimeters. For doses 
above $80 \mathrm{mrem}$, the accuracy improved to better than 10\% when a common calibration was used. Individual differences found in this study may reflect differences in calibration technique rather than differences in the dose rates of actual calibration standards. Second, at dose rates above $100 \mathrm{mrem}$, the precision for the best participants was generally below $\pm 10 \%$ which is also within expected limits for these types of dosimeters. The poorest results had a standard deviation of about $\pm 25 \%$. At the lowest doses, which were sometimes below the lower detection limit, the precision often approached or exceeded $\pm 100 \%$. Third, the lower level of detection for free field ${ }^{252} \mathrm{Cf}$ neutrons generally ranged between 20 and $50 \mathrm{mrem}$. Fourth, the energy dependence study provided a characterization of the response of the dosimeters to neutron energies far from the calibration energy. This information confirmed the known significant neutron energy response dependence for conventional personnel dosimeters, and reaffirms the need for appropriate calibration factors to provide an accurate determination of neutron dose equivalent. 


\section{A.CKNOWLEDGMENT}

Several people were instrumental in the successful completion of this effort. The involvement of people at each participating laboratory is gratefully acknowledged. Their comments during the course of the program and on the draft copy of this report are very much appreciated. E. J. Vallario is the DOE Program Manager for this Personnel Neutron Evaluation and Upgrade Program, and his interest in the successful completion of this effort is gratefully appreciated. Yo T. Song and John Taylor, chairmen of the Program Review Committee and the Program Scientific Advisory Committee, respectively, were instrumental in defining the scope of the intercomparison task. Special acknowledgment is due Pat Sickle of PNL who coordinated the receipt, irradiation, and return of the many dosimeters involved in this effort. 


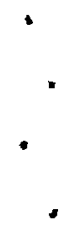


CONTENTS

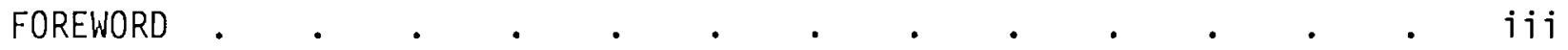

EXECUTIVE SUMMARY

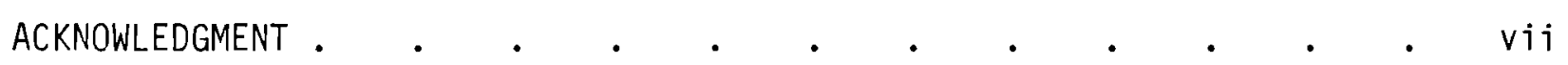

INTRODUCTION

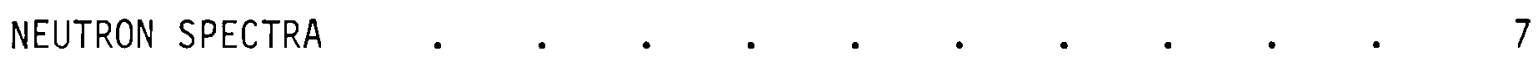

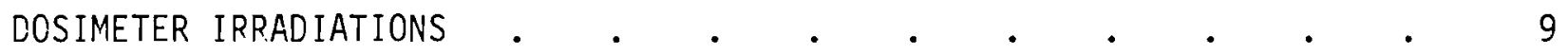

NATIONAL BUREAU OF STANDARDS $\quad . \quad . \quad . \quad . \quad . \quad . \quad . \quad$.

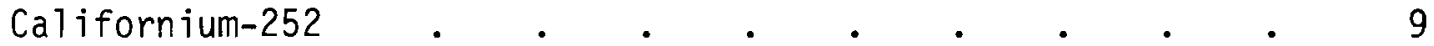

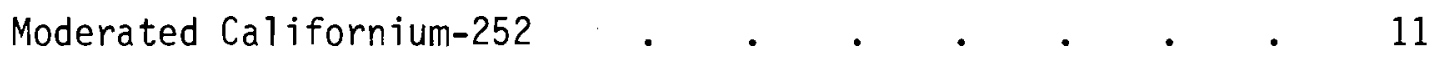

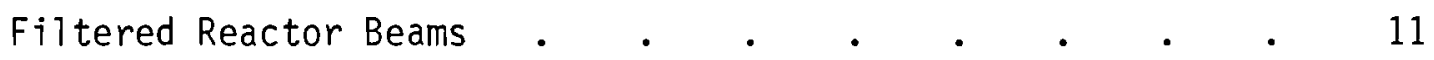

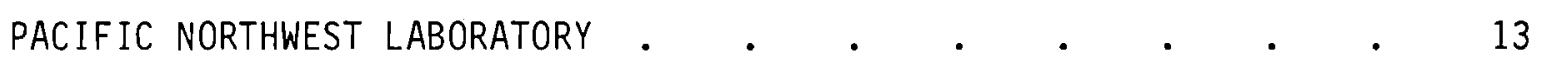

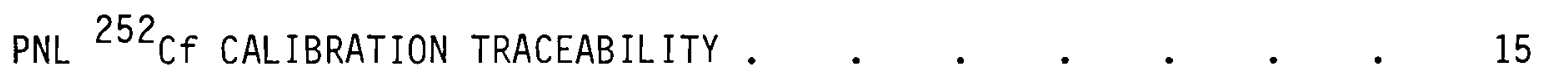

${ }^{252}$ CF SOURCE DOSE CALCULATION .

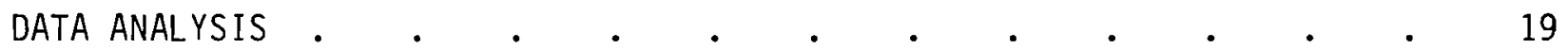

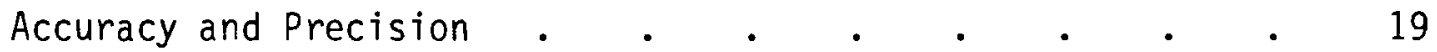

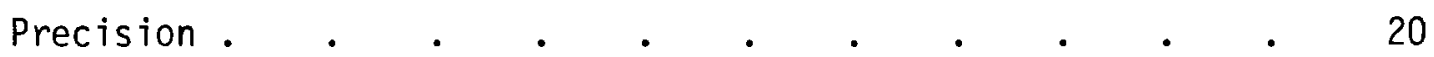

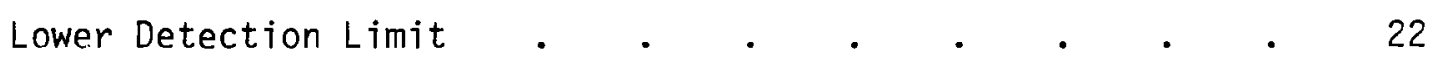

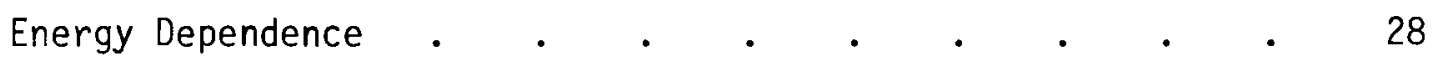

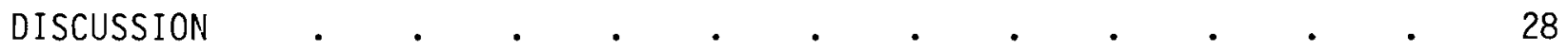

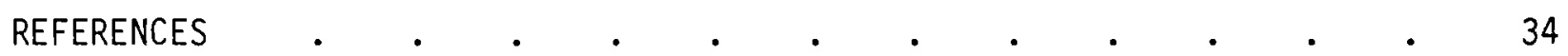

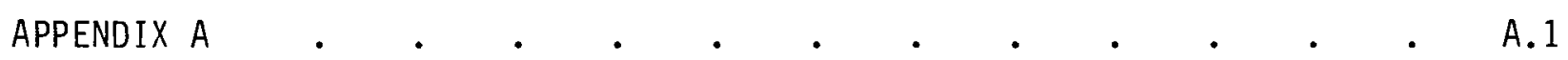




\section{FIGURES}

1 Schematic Representation of Some TLD-Albedo Dosimeters Used at DOE Facilities

2 Participant Dosimeters Used in Irradiations . $\quad . \quad$. $\quad$. $\quad 4$

3 NTA Response as a Function of Neutron Energy . . . . . . 5

4 Energy Dependence of Various Albedo Dosimeters . $\quad$. $\quad$. 6

5 Neutron Spectra Measured by a Multisphere Spectrometer at

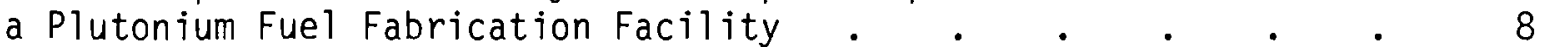

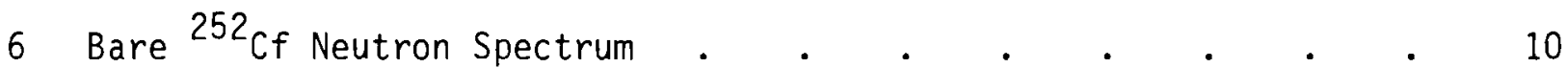

7 Moderated Fission Source Spectrum . . . . . . . . 10

8 Nominal $2 \mathrm{keV}$ Filtered Reactor Beam . . . . . . . . 12

9 Nominal $24 \mathrm{keV}$ Filtered Reactor Beam . . . . . . . 12

10 Nominal $144 \mathrm{keV}$ Filtered Reactor Beam . . . . . . . . 13

11 Schematic Diagram of Low-Scatter Irradiation Room . . . . 14

12 The ${ }^{252} \mathrm{Cf}$ Irradiation Geometry . . . . . . . . . 15

13 Neutron Room Scatter Determined Using the PNL Laboratory Dosimeter . . . . . . . . . . . . . . 17

14 Bias for Various Dose Levels for Phase 1 and Phase 2 . . . 22

15 Precision for Various Dose Levels for Phase 1 and Phase 2 . $\quad 23$

16 Plot of Accuracy for Phase 1 and Phase 2 Data . . . . . 25

17 Plot of Precision for Phase 1 and Phase 2 Data $\quad$. . . 25

18 Histograms of Estimated Lower Detection Limits for All Contractors at 3 Levels of Acceptable Error 5\%, $10 \%$ and $20 \%(\alpha=\beta)$. $\quad . \quad . \quad . \quad . \quad . \quad . \quad . \quad . \quad 27$

19 Histograms of Neutron Dosimeter Response in a High Scatter Environment (HS) Compared to a Low Scatter Environment (LS) . . . 29

20 Histograms of the Accuracy of Neutron Dosimeter Response During Phase 3 Irradiations to Moderated ${ }^{252} \mathrm{Cf}$ by Irradiation Level 
21 Histograms of the Accuracy of Neutron Dosimeter Response to Three Energies of Monoenergetic Neutron Beams . . .

22 Histograms of the Accuracy of Neutron Dosimeter Response to

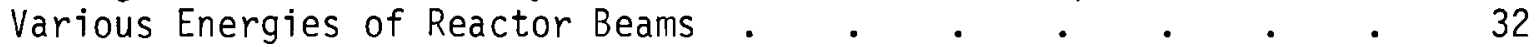

\section{TABLES}

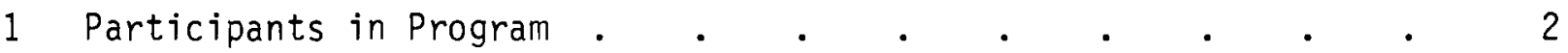

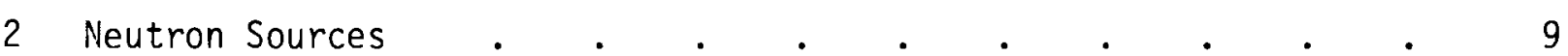

3 Number of Neutron Dosimeter Irradiations by Month, Radiation Type and Exposure Level . . . . . . . 20

A.1 Means and Standard Deviations (SD) of Phase 1 Neutron Dosimeter Response Reported by Contractor and Irradiation Level . . . A.1

A.2 Mean and Standard Deviation Summary of February Data, Phase 1 A A.2

A.3 Mean and Standard Deviation Summary of March Data, Phase 1 . . A.3

A.4 Mean and Standard Deviation Summary of April Data, Phase 1 . . A.4

A.5 Accuracy of Phase 1 Neutron Dosimeter Response as Measured

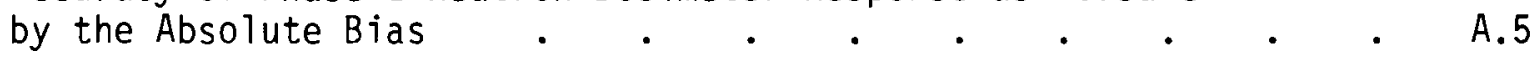

A.6 Precision of Phase 1 Neutron Dosimeter Response as Measured by the Coefficient of Variation . . . . . . . . . . A.6

A.7 Means and Standard Deviations (SD) of Phase 2 Neutron Dosimeter Response Reported by Contractor and Irradiation Level . . . A.7

A.8 Mean and Standard Deviation Summary of February Data, Phase 2 A A.8

A.9 Means and Standard Deviations of March Data, Phase 2 . . . A.9

A.10 Mean and Standard Deviation Summary of April Data, Phase 2 . . A.10

A.11 Accuracy of Phase 2 Neutron Dosimeter Response as Measured by the Absolute Bias . . . . . . . . . . A.11

A.12 Precision of Phase 2 Neutron Dosimeter Response as Measured by the Coefficient of Variation . . . . . . . . . A.12

A.13 Regression Analysis of Neutron Dosimeter Response . . . . . A.13 


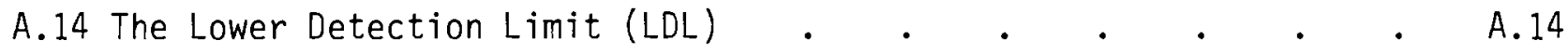

A.15 Means and Standard Deviations (SD) of Phase 3 Neutron Dosimeter Irradiated with an Unmoderated Californium Source in a High Scatter Facility

A.16 Accuracy of Neutron Dosimeter Response to a High Scatter Facility . . . . . . . . . . . . . . . A.16

A.17 Precision of Neutron Dosimeter Response to the High Scatter Environmental as Reported by Contractor and Irradiation Level . A.17

A. 18 Means and Standard Deviations of Neutron Dosimeter Response to Moderated Californium . $. \quad . \quad . \quad . \quad . \quad . \quad . \quad A .18$

A.19 Accuracy of Dosimeter Response to Unmoderated Californium as Measured by the Absolute Bias . . . . . . . . A.19

A.20 Means and Standard Deviations of Dosimeter Response to Accelerator

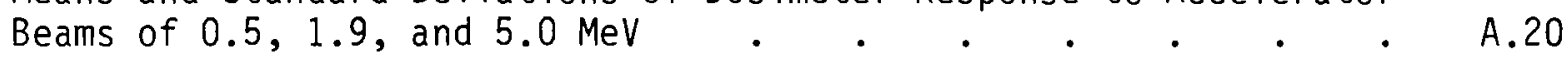

A.21 Accuracy of Neutron Dosimeters Irradiated by Accelerator Beams of $0.5,1.9$, and $5.0 \mathrm{MeV}$. . . . . . . . . A.21

A.22 Mean and Standard Deviation Summary of Neutron Dosimeter Response to Reactor Beams of Various Energies . . . . A.22

A.23 Accuracy of Neutron Dosimeters Irradiated by Reactor Beams of

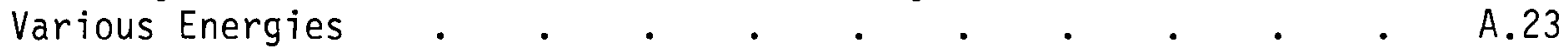




\section{RESPONSE CHARACTERISTICS OF SELECTED \\ PERSONNEL NEUTRON DOSIMETERS}

\section{INTTRODUCTION}

Performance characteristics of selected personnel neutron dosimeters in current use at Department of Energy (DOE) facilities were determined from their evaluation of neutron dose equivalent received after irradiations with specific neutron sources at either the National Bureau of Standards (NBS) or the Pacific Northwest Laboratory(a) (PNL). The characteristics assessed included: lower detection level, energy response, precision and accuracy. The data collected were evaluated in three phases:

Phase 1 - Dosimeter irradiations were carried out during February, March, and April of 1981, consistent with ANSI N13.11 (American National Standards Institute 1978) recommendations, and the dose equivalent was evaluated using participant-specific calibration data.

Phase 2 - Re-evaluation of Phase 1 dosimeter results was performed by participants using PNL-supplied calibration data appropriate to the irradiation laboratory's neutron sources.

Phase 3 - Subsequent irradiations during May, June, July, and August 1981 were carried out using additional neutron sources, including a moderated ${ }^{252} \mathrm{Cf}$ source, a ${ }^{252} \mathrm{Cf}$ source in a high scatter facility, and monoenergetic neutrons using the PNL Van de Graaff accelerator and NBS reactor filtered beams.

The DOE laboratories participating in the program are shown in Table 1. The procedure for carrying out the intercomparion was as follows: Each month, 35 dosimeters including 5 control dosimeters were submitted to PNL for irradiation by each participant. PNL coordinated the irradiation of dosimeters between NBS and PNL. After irradiation, the dosimeters were returned to the

(a) Operated by Battelle Memorial Institute. 


\title{
TABLE 1. Participants in Program
}

\author{
Argonne National Laboratory (ANL) \\ Brookhaven National Laboratory (BNL) \\ Hanford \\ Idaho National Engineering Laboratory (INEL) \\ Los Alamos National Laboratory (LANL) \\ Lawrence Livermore National Laboratory (LLNL) \\ Mound Laboratory \\ Nevada Test Site (NTS) \\ Pantex \\ Rocky Flats Plant (RFP) \\ Sandia Laboratories \\ Savannah River Plant (SRP)
}

respective laboratories for evaluation. The analysis and presentation of results in this report are strictly blind, in that no identification of the laboratories is shown in the data tables.

The types of dosimeters included in this study were, for the most part, TLD-albedo designs. However, the nuclear track emulsion (NTA) film dosimeter is still in use and was included in this study due to its ability to respond to high energy neutrons. Several variations of the basic albedo principle of detecting neutrons reflected from the body as well as incident thermal neutrons using ${ }^{6}$ LiF and ${ }^{7}$ LiF TLDs have been developed. Figure 1 shows some typical dosimeter configurations.

Figure 2 shows the dosimeters used in this study. This figure helps to point out that the dosimeters have different geometrical configurations and probably employ different calibration, processing, and dose determining procedures.

It is difficult to define the basic mechanisms that result in a high or a low accuracy dosimeter. The overall performance of each dosimeter is a combination of the dosimeter design as well as processing, calibration and dose algorithm procedures. The physical principles upon which each dosimeter type relies for its response do not necessarily limit accuracy. The dosimeter 


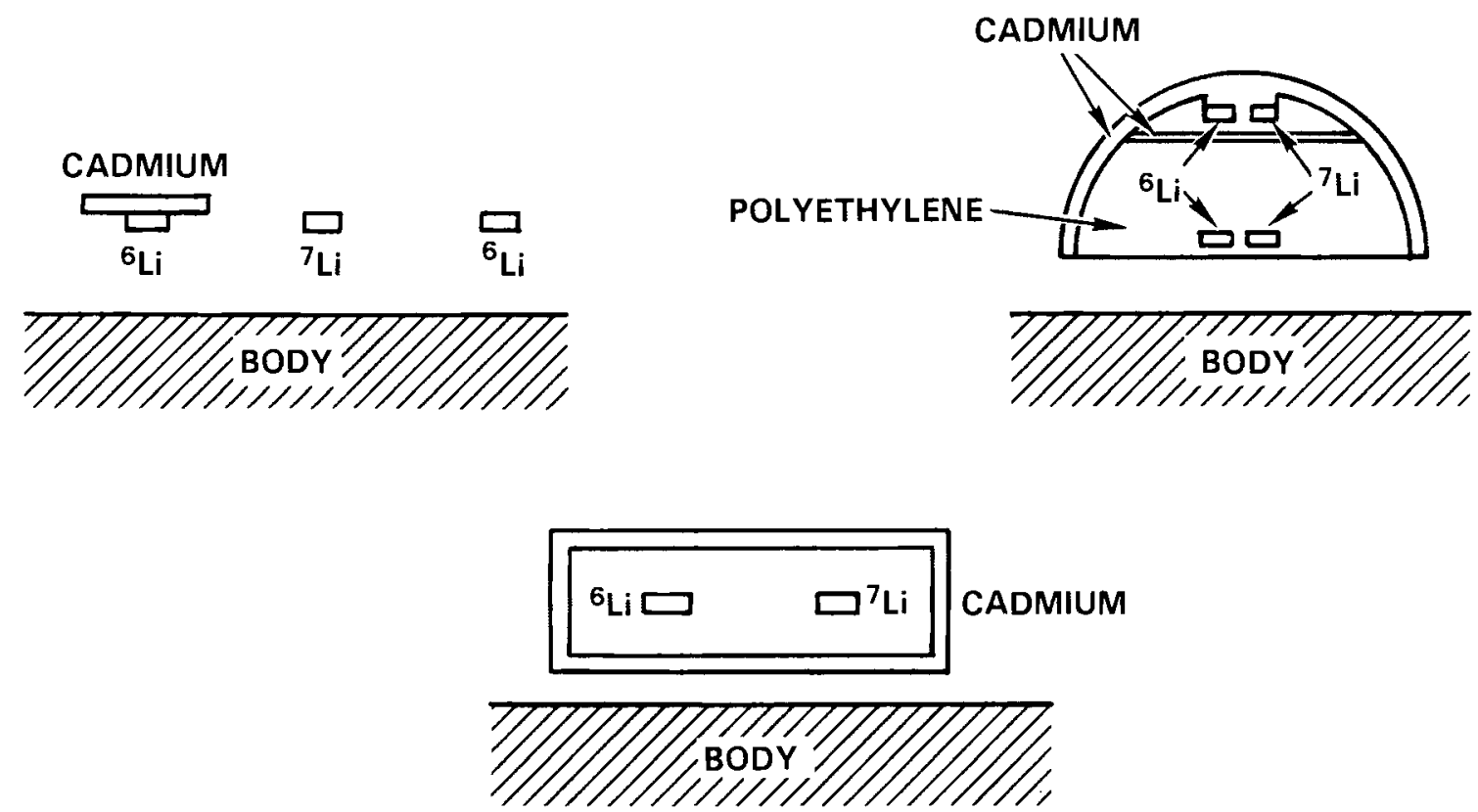

FIGURE 1. Schematic Representation of Some TLD-Albedo Dosimeters Used at DOE Facilities

response as a function of neutron energy is complex, and it is also dependent upon the physical principles of operation and upon the details of construction and calibration.

Neutrons produce most of their effects in solids by means of secondary charged particles resulting from elastic and inelastic scattering, nuclear interactions, and the eventual generation of protons, alpha particles, electrons and possibly heavy charged particles. The energy spectra and angular distributions of these charged particles are intricate, and in some cases, poorly known. Therefore, it is difficult to accurately characterize the response to neutrons for even the simplest dosimeter. For example, consider the case of dosimeters based on the use of nuclear emulsions, which rely on the registration of charged particle tracks that are visible after development, and can be counted using optical means. A plot of the response function for a typical nuclear emulsion is shown in Figure 3. The yield of tracks per neutron as a function of neutron energy for Kodak Type A film rises from about $500 \mathrm{keV}$ to a maximum at about $7 \mathrm{MeV}$ and then begins to fall (Dudley 1966). This response may be due to a situation where more than the energy necessary 


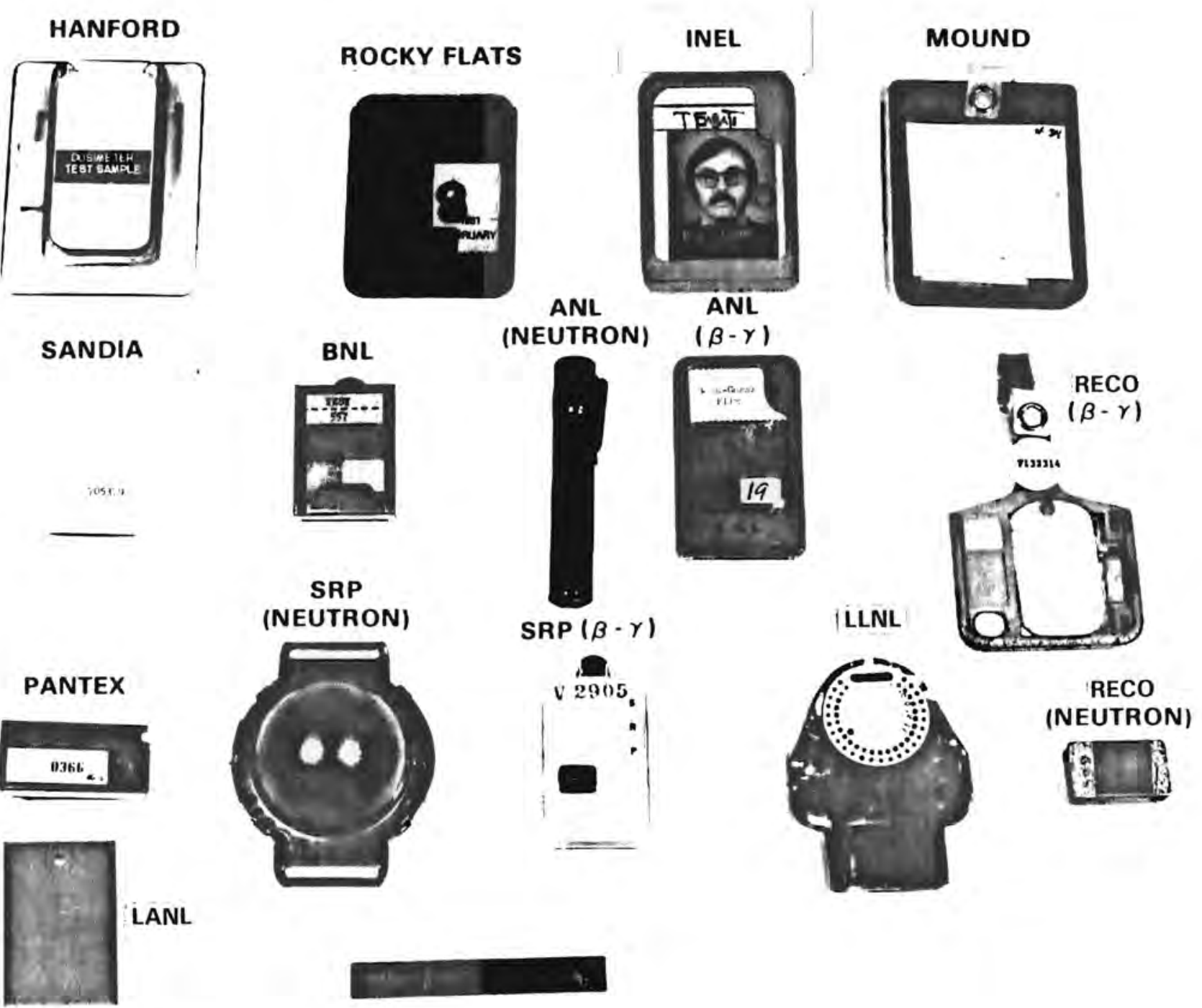

FIGURE 2. Participant Dosimeters Used in Irradiation 


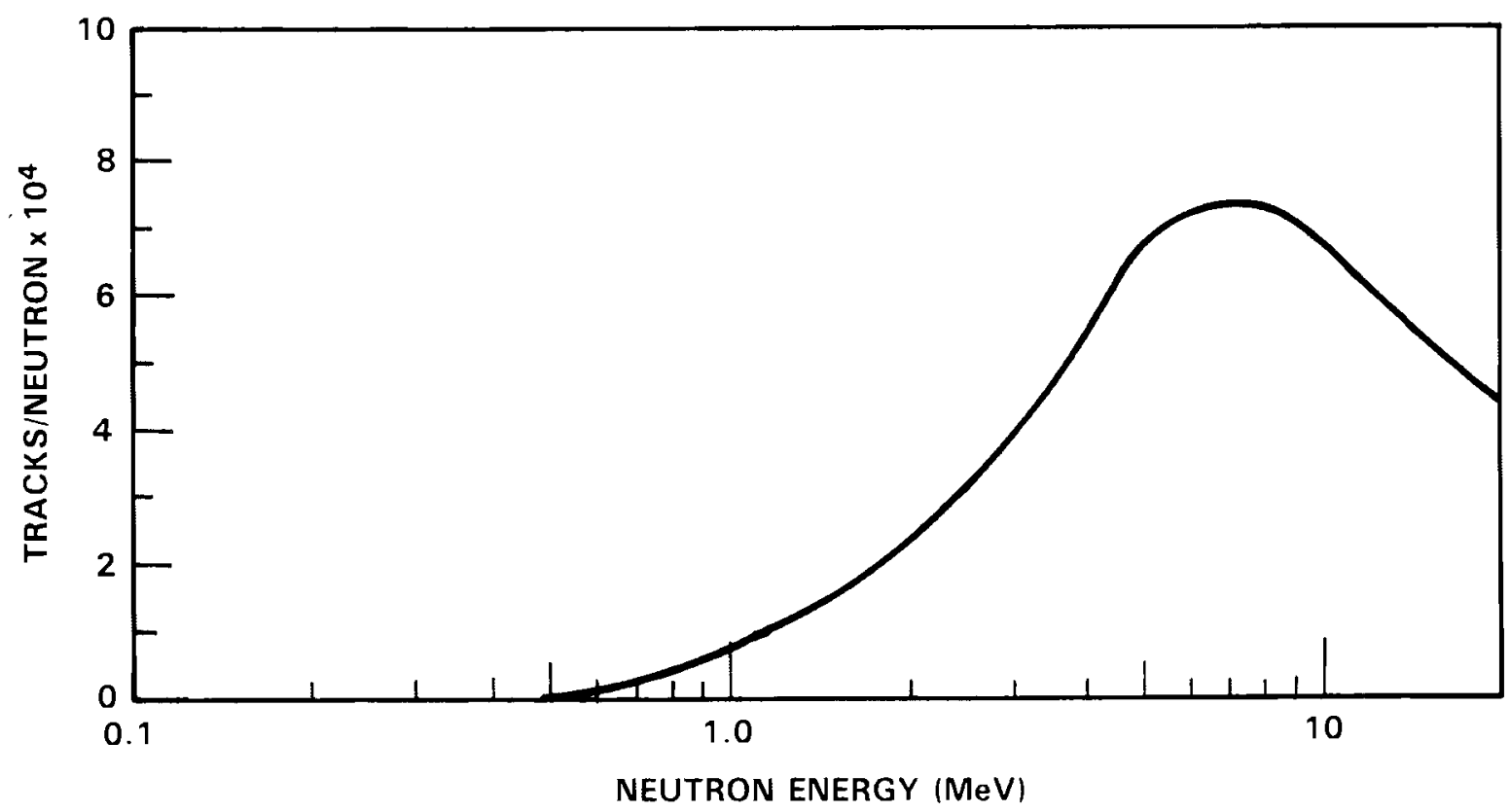

FIGURE 3. NTA Response as a Function of Neutron Energy (Dudley 1966)

to produce an effect is deposited locally by the densely ionizating secondary charged particles from higher energy neutrons. Since the statistical uncertainty is large for low neutron doses and the response to low energy neutrons rapidly decreases for nuclear emulsions, it can be expected that their performance under such conditions will be poor.

TLD sensitivity to low and intermediate energy neutrons is generally quite good due to its inherently larger quantum efficiency. A single charged particle can excite an electron to the conduction band from which it can migrate to a trap and, on subsequent heating, recombine with a free hole to produce a visible light photon. On the other hand, a charged particle track may not be produced in an emulsion unless the particle has sufficient energy. Low doses result in very few individual tracks which are difficult to detect.

The energy response of TLD albedo dosimeters is also complex due to the response of the phosphors themselves and the details of the irradiation geometry (Brackenbush 1980). In general, they are very sensitive to low and intermediate energy neutrons. The response as a function of neutron energy for three types of TLD is shown in Figure 4 (Piesch 1978). The response for 


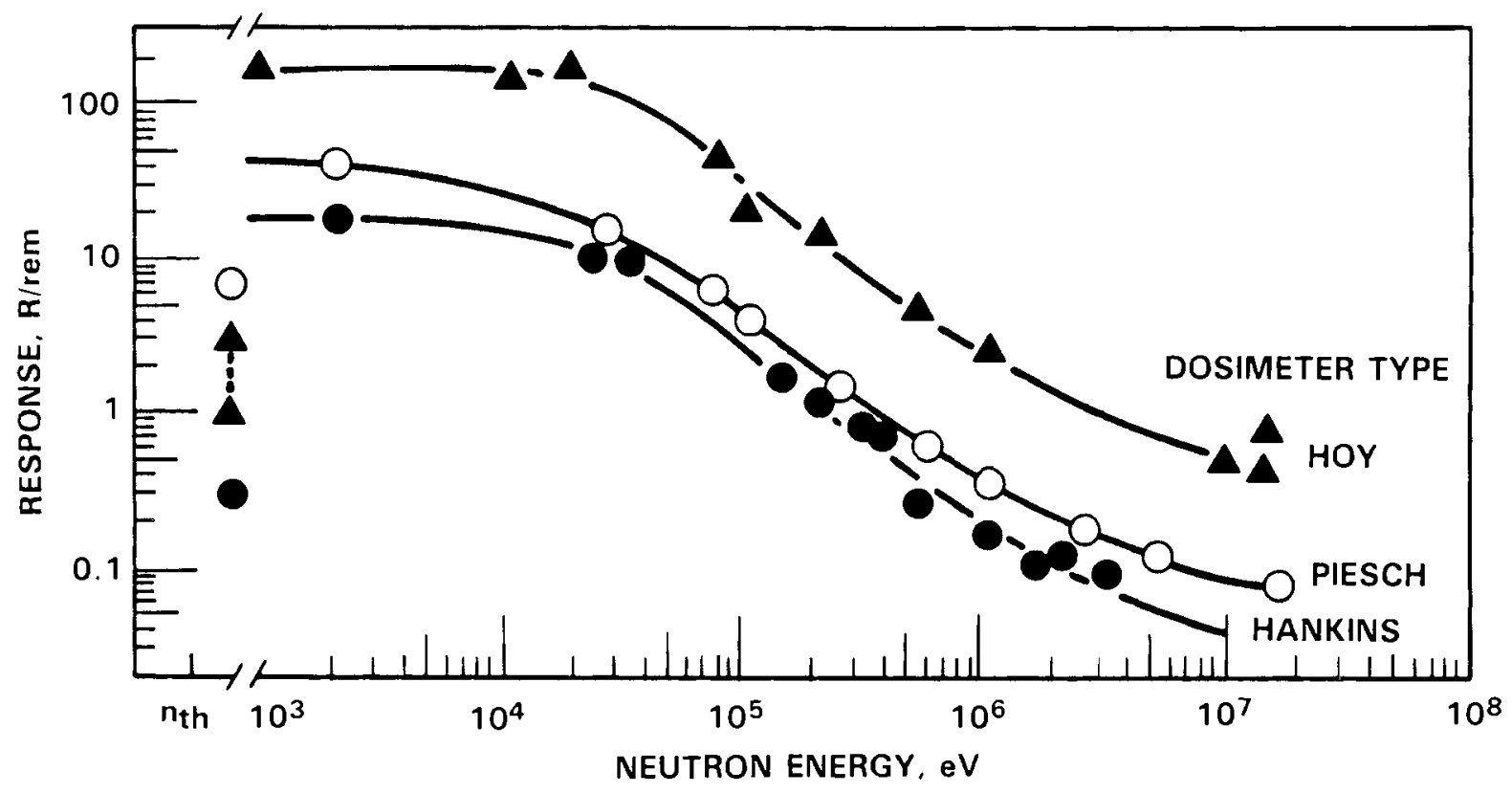

FIGURE 4. Energy Dependence of Various Albedo Dosimeters (Piesch and Burgkhardt 1978)

of al1 the TLDs, begin to decrease above $10 \mathrm{keV}$ and continues to decrease exponentially for higher neutron energies. From this figure, it is clear as to why it is difficult to obtain accurate dose results for the variety of neutron spectra encountered in the work environment.

Both TLD and NTA films are subject to several sources of uncertainty in the repeated determination of dosimeter response to the same given dose. TLD phosphors may not be completely uniform and it is generally not practical to establish a calibration factor for each individual dosimeter. Counting tracks in NTA films is a statistically variable process. It is necessary to count a relatively large number of tracks for good statistics, however, counting large numbers may again be impractical. Therefore, a compromise must be achieved which will affect precision.

Each of these dosimeters is inherently quite sensitive in terms of absorbed dose within certain energy ranges, but there are limits to the signal-to-noise ratio for each one. Basically, the limiting processes are at work in the readout systems. TLD systems are limited by photomultiplier dark current and 
sample holder heating incandescence. NTA films are affected by environmental factors such as heat, light, and moisture.

The response of a personnel dosimeter to neutrons can be represented by the integral of the dosimeter response function $R(E)$ over the neutron energy spectrum $N(E) d E$,

$$
D=\int_{E_{\min }}^{E_{\max }} R(E) N(E) d E
$$

where $D$ represents the total dosimeter response. In practice, the dosimeter response is determined with a calibration source and this response is used to evaluate the dose received during field use. It is important to note that since the response functions are strongly energy dependent, the calibration source spectrum is critical. For instance, it is easy to see that if one uses a calibration source with an energy spectrum primarily above $1 \mathrm{MeV}$ and a measurement is taken in a low energy field, then the dose may be overestimated by some orders of magnitude (see Figures 3 and 6 ).

\section{NEUTRON SPECTRA}

Neutron energies encountered in the laboratory and in the field extend over many orders of magnitude. Neutron spectral measurements with a multisphere system are shown in Figure 5 for a plutonium fuel fabrication facility (Aldrich 1981). The average energies as calculated are:

- $530 \mathrm{keV}$ in the fuel storage pit area

- $576 \mathrm{keV}$ in the plutonium storage vault

- $660 \mathrm{keV}$ in the fuel pin storage box area

- $1.1 \mathrm{MeV}$ in the pin storage area

- $1.5 \mathrm{MeV}$ at the midpoint of the bare fuel subassembly.

The unmoderated and slightly moderated neutron fields result in high energy spectra. In the storage pit and vault there is a higher contribution of thermal and intermediate neutrons because of neutron scattering in the additional shielding and from the building. 


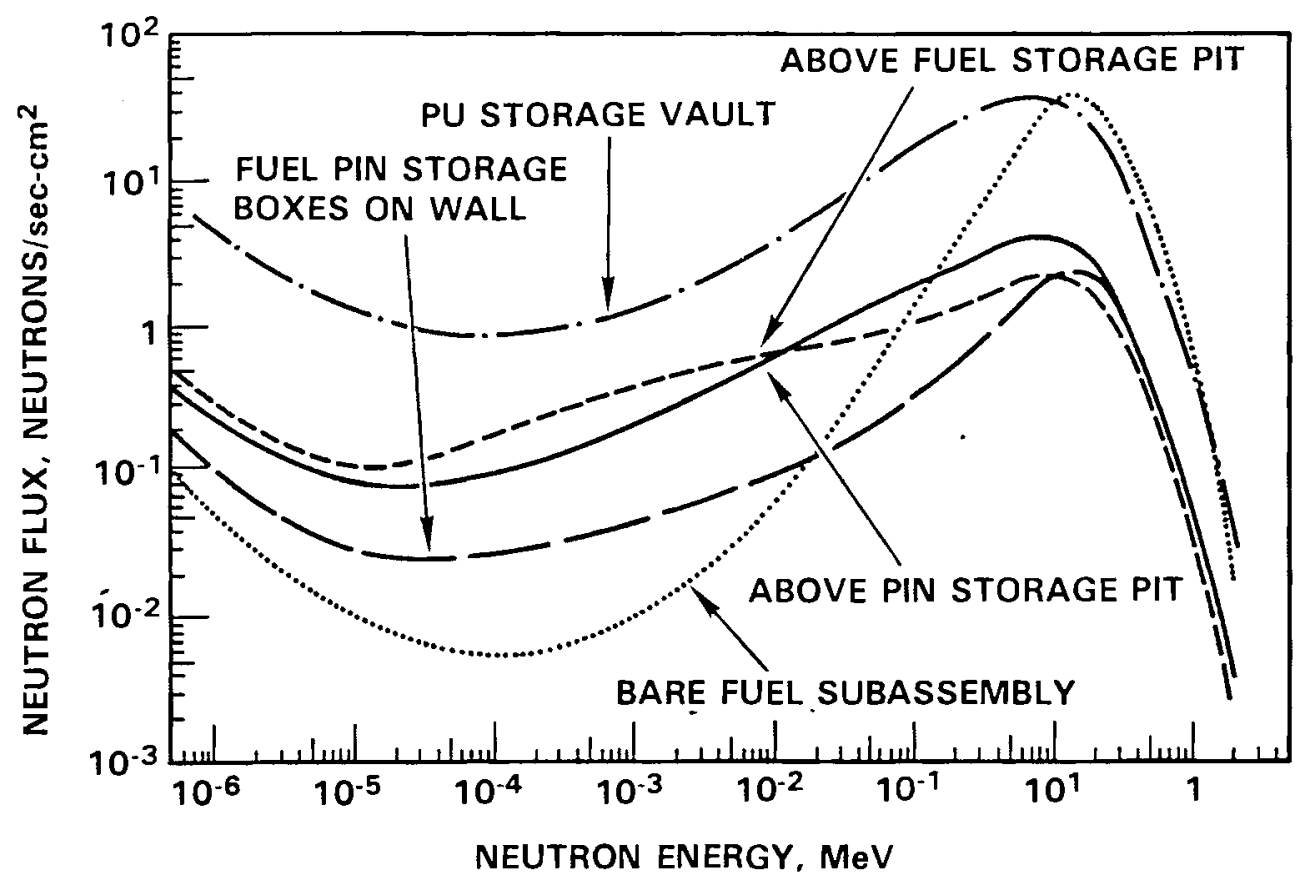

FIGURE 5. Neutron Spectra Measured by a Multisphere Spectrometer at a Plutonium Fuel Fabrication Facility (Aldrich et al. PNL-3536, Study 4, 1981) 


\section{DOSIMETER IRRADIATIONS}

Sources of neutron radiation used in this program are 1 isted in Table 2 from NBS and PNL. Several measurements were made to characterize the neutron spectra and dose equivalent from these sources using two and five-inch tissue equivalent Bonner spheres and laboratory evaluated personnel dosimeters.

\section{TABLE 2. Neutron Sources}

$\underline{\text { NBS }}$

- unmoderated ${ }^{252} \mathrm{Cf}$

- moderated ${ }^{252} \mathrm{Cf}$.

- monoenergetic neutrons of 2, 24, and $144 \mathrm{keV}$

$\underline{P N L}$

- unmoderated ${ }^{252} \mathrm{Cf}$

- high scatter geometry ${ }^{252} \mathrm{Cf}$

- monoenergetic neutrons between $100 \mathrm{keV}$ and $4 \mathrm{MeV}$ using the PNL Van de Graaff accelerator and selected targets

\section{NATIONAL BUREAU OF STANDARDS}

Neutron irradiations at NBS were carried out using a moderated and an unmoderated ${ }^{252} \mathrm{Cf}$ source, a $15 \mathrm{~cm} \mathrm{D} 20$ moderated ${ }^{252} \mathrm{Cf}$ source, or one of the beams from a 10 megawatt reactor. Figures 6 and 7 show the spectra from unmoderated and moderated ${ }^{252} \mathrm{Cf}$ source as calculated by Schwartz (1980) and Grund1 (1975).

\section{Cal ifornium-252}

\section{Unmoderated}

The NBS ${ }^{252}$ Cf source is a lightly encapsulated source which is pulled up by a string into an aluminum $j i g$ which fixed its position during irradiation. The source is housed in a low scatter area of an accelerator target pit with a 


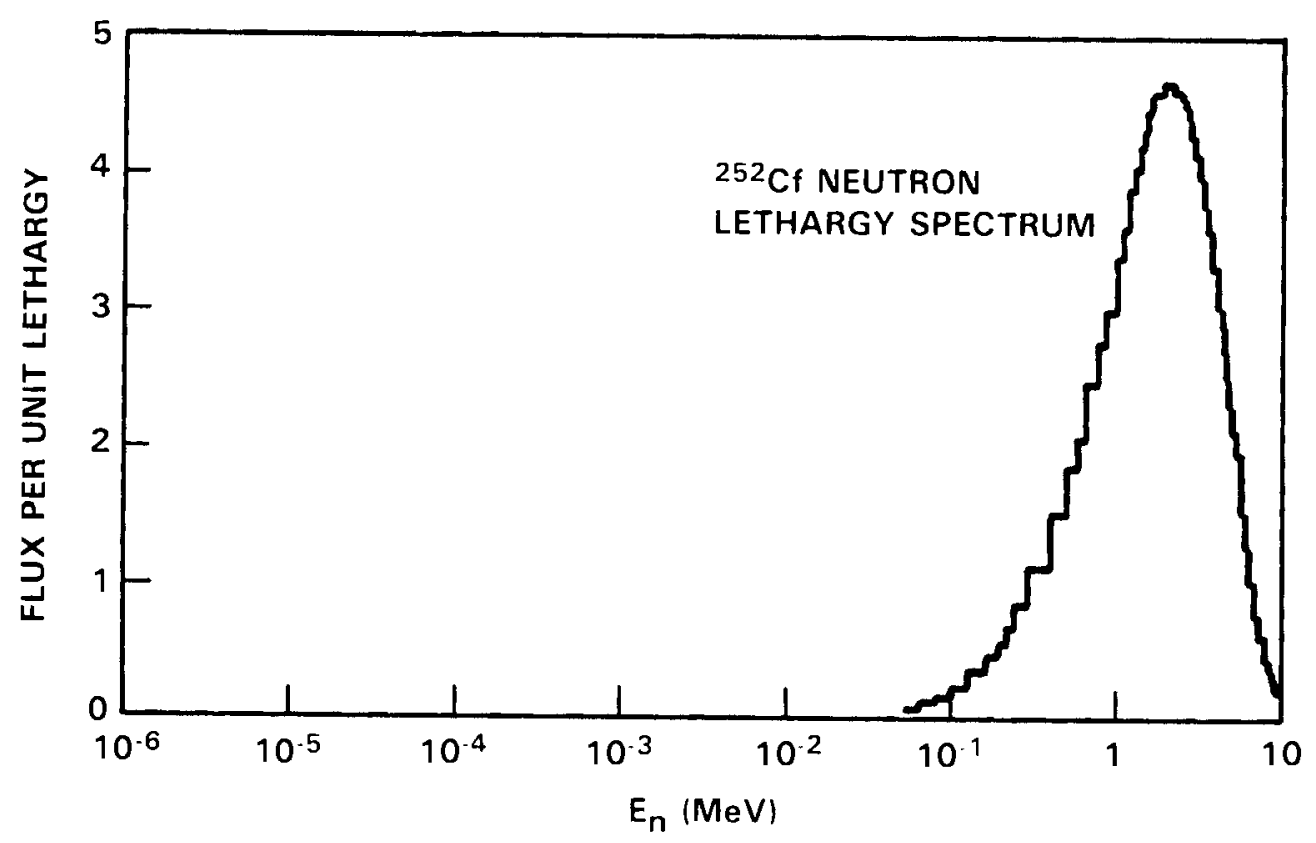

FIGURE 6. Bare ${ }^{252} \mathrm{Cf}$ Neutron Spectrum

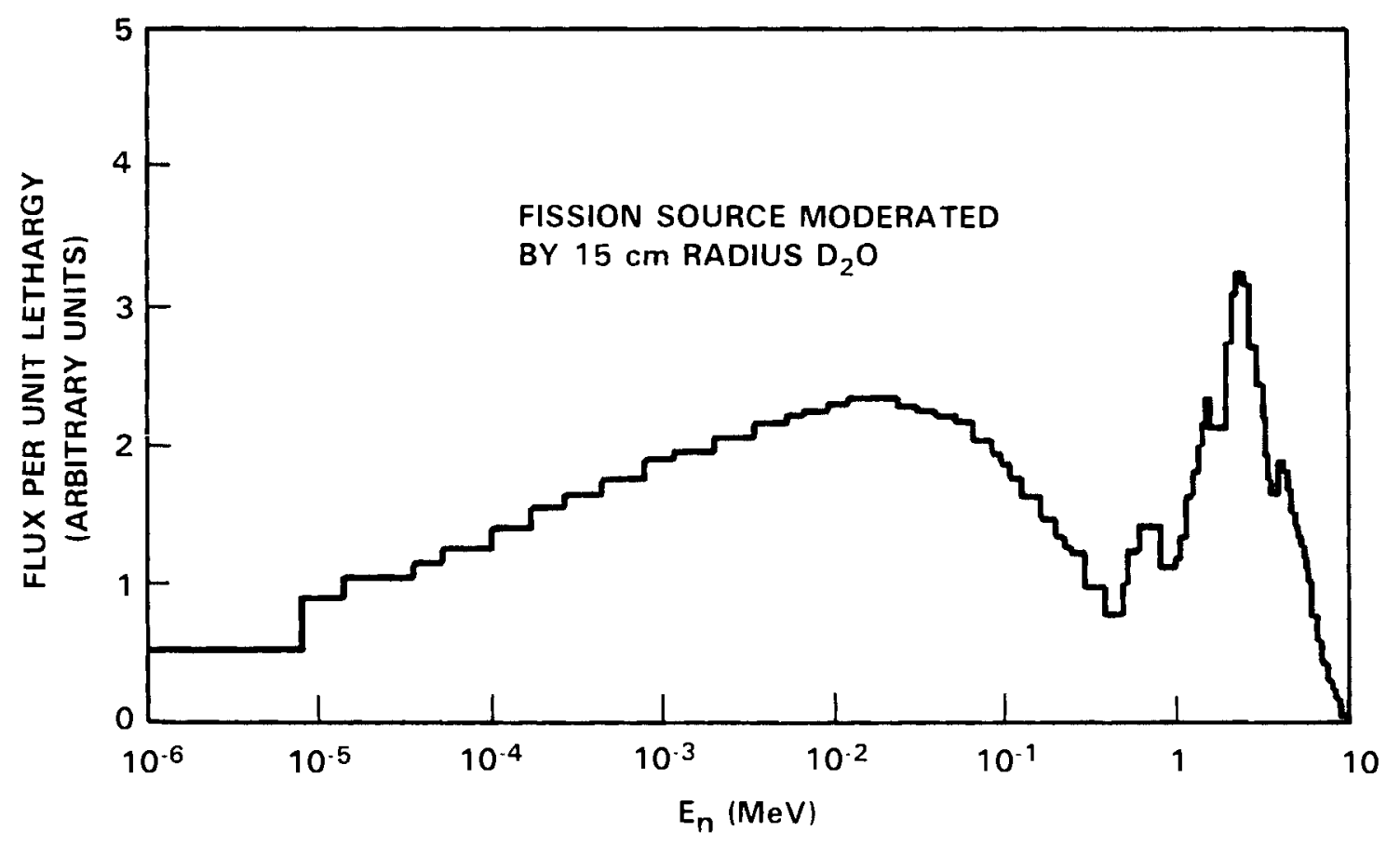

FIGURE 7. Moderated Fission Source Spectrum 
grid floor. Lightweight aluminum scaffolding provides a mounting platform for the phantom and dosimeters. The room is approximately $11 \mathrm{~m} \times 11 \mathrm{~m} \times 11 \mathrm{~m}$ and the source is stored in a well within the floor.

Moderated Cal ifornium-252

A moderated ${ }^{252} \mathrm{Cf}$ spectrum is achieved by using an assembly with a cadmium-covered $15-\mathrm{cm}$ radius sphere of $\mathrm{D}_{2} \mathrm{O}$ with a ${ }^{252} \mathrm{Cf}$ source at the center. Several measurements were made to determine the uncertainty in the calculated dose equivalent rate. The overall uncertainty compared to the unmoderated californium source is estimated to be $\pm 3 \%$ exclusive of any uncertainties in fluence to dose equivalent conversion factors. The uncertainty in the dose equivalent rate from the moderated source is, however, estimated to be $\pm 15 \%$. This is almost entirely due to uncertainties in the details of the spectrum shape (Schwartz 1982).

\section{Filtered Reactor Beams}

Three nearly monoenergetic beams in addition to a thermal beam are available from the 10 megawatt NBS reactor. These beams are available using selected filters having sufficiently small cross-sections over small energy bands to allow transmission of neutrons of nearly the same energy (Schwartz 1977). These are described as follows:

1. $2 \mathrm{keV}$. Scandium filtered beam with $97 \%$ of the flux density in the $2 \mathrm{keV}$ region.

2. $24.3 \mathrm{keV}$. Iron-aluminum filtered beam with $97 \%$ of the flux density within the main peak. The other $3 \%$ is in higher energies.

3. $144 \mathrm{keV}$. Silicon filtered beam with two peaks: $98 \%$ and $1.5 \%$ of flux density are within $144 \mathrm{keV}$ and $51 \mathrm{keV}$ peaks, respectively.

The measured spectra for the filtered beams are shown in Figures 8 through 10 . The filtered beams are very small being about 1 -inch in diameter and well collimated. The beams travel through a port about 1 meter in length. At a distance of 2 meters, the beams are only about 2 -inches $(5 \mathrm{~cm})$ diameter. For these irradiations, dosimeters are mounted on a $30-\mathrm{cm}$ by $30-\mathrm{cm}$ phantom, $15-\mathrm{cm}$ in thickness. A $25-\mathrm{cm}$ by $25-\mathrm{cm}$ scan of the dosimeters is done using beams of 


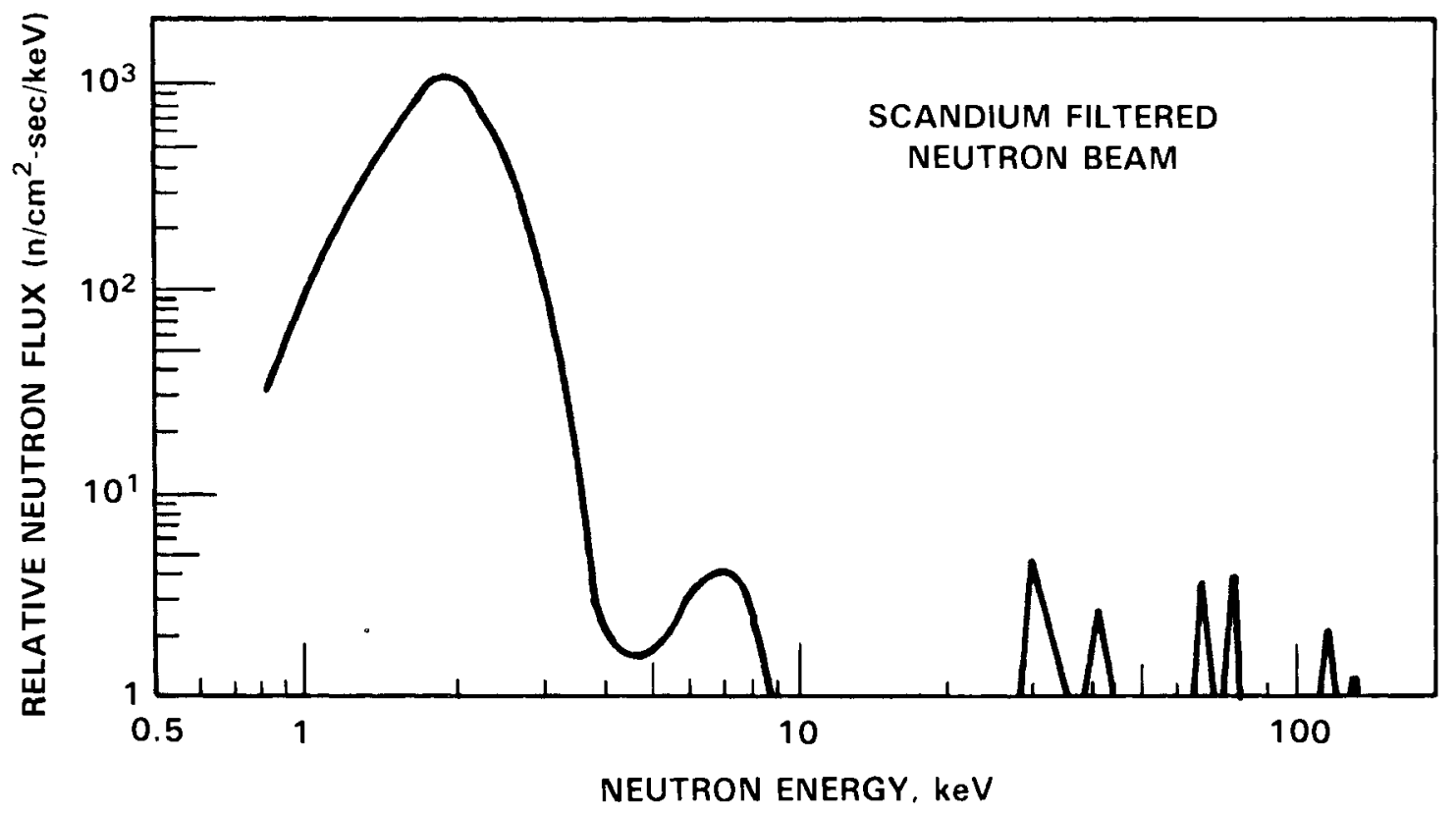

FIGURE 8. Nominal $2 \mathrm{keV}$ Filtered Reactor Beam

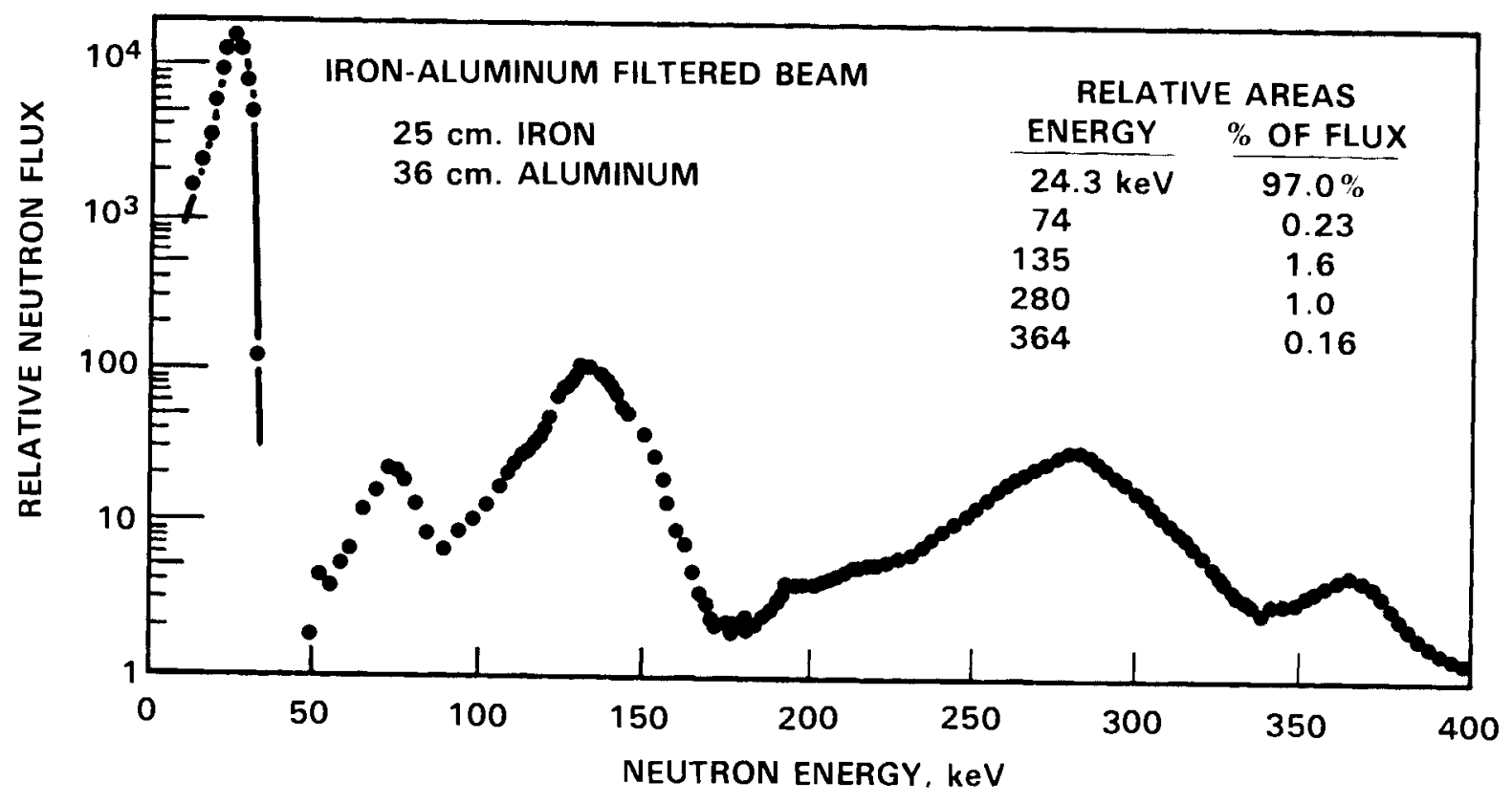

FIGURE 9. Nominal $24 \mathrm{keV}$ Filtered Reactor Beam 


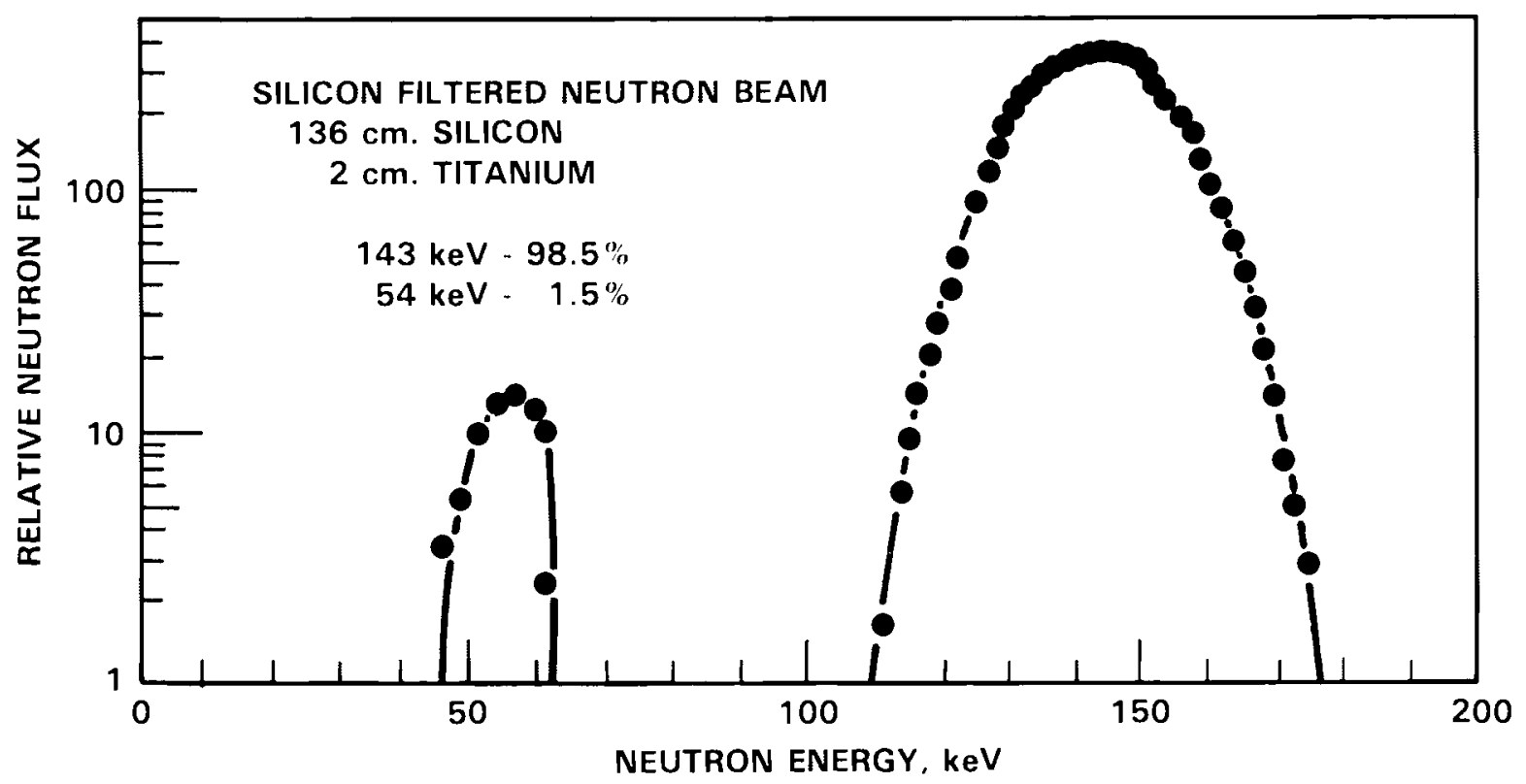

FIGURE 10. Nominal $144 \mathrm{keV}$ Filtered Reactor Beam

$5 \mathrm{~cm}$ in diameter and a flux density of $5 \times 10^{4} \mathrm{n} / \mathrm{cm}^{2}-\mathrm{sec}$. The dosimeters on their phantom are scanned to achieve uniform irradiation, using an $x-y$ motor drive.

PACIFIC NORTHWEST LABORATORY

Dosimeters were irradiated using an unmoderated ${ }^{252} \mathrm{Cf}$ source in the 318 facility, an unmoderated ${ }^{252} \mathrm{Cf}$ source in a high scatter geometry in the $3645 \mathrm{~A}$ facility, and monoenergetic neutron beams using the PNL Van de Graaff accelerator.

A relatively large room is desirable for neutron irradiations because of the large amount of secondary scattering from room surfaces (Schwartz and Eisenhauer 1982). The room dimensions in the 318 facility are shown in Figure 11. The minimum distance to a room surface if $4.1 \mathrm{~m}$ for the ${ }^{252} \mathrm{Cf}$ source. A11 room surfaces are made of concrete.

The ${ }^{252} \mathrm{Cf}$ source is pulled into position using a cord-and-pulley system. The source moves inside stainless-steel tubing. It is stored inside a 

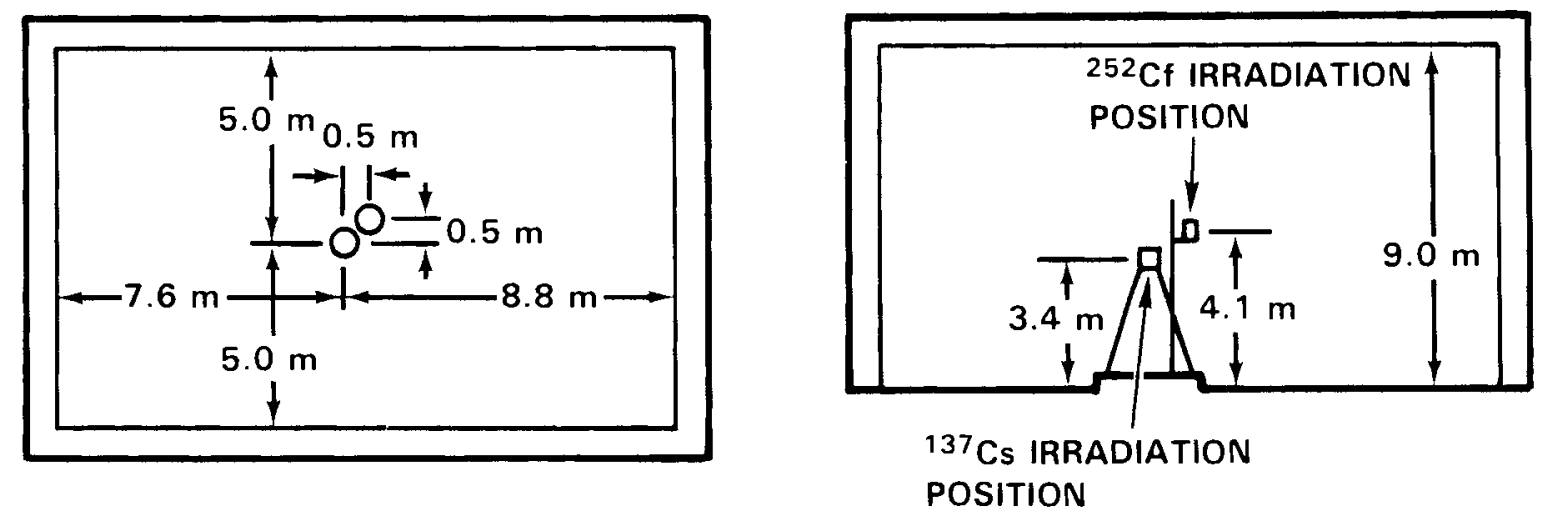

FIGURE 11. Schematic Diagram of Low-Scatter Irradiation Room

paraffin-filled drum. The irradiation geometry for the ${ }^{252} \mathrm{Cf}$ source is shown in Figure 12. The source is pulled into the irradiation position, at a height corresponding to the center of the phantom. The dosimeters are irradiated on the front face of a $30 \mathrm{~cm} \times 30 \mathrm{~cm} \times 15 \mathrm{~cm}$ water-filled phantom. The distance between the source center and the front face of the phantom is $50 \mathrm{~cm}$. The ${ }^{252} \mathrm{Cf}$ source (approximately $9 \mu \mathrm{g}$ ) in the form of a cylinder $23.1 \mathrm{~mm}$ long by $2.8 \mathrm{~mm}$ in diameter, encapsulated by $0.88 \mathrm{~mm}$ of iridium and platinum.

Aluminum scaffolding is used to provide platforms for mounting dosimeters and equipment. The scaffolding does not contribute a measurable amount of scattered radiation to the ${ }^{252} \mathrm{Cf}$ exposures.

\section{Van de Graaff Accelerator}

The neutron irradiation facility at the PNL Van de Graaff accelerator laboratory has a neutron producing target located over the center of a $6 \mathrm{~m} \mathrm{x}$ $6 \mathrm{~m}$ pit and grid flooring, with the target $3 \mathrm{~m}$ from the pit floor.

Irradiations using a tritium target were done at $45^{\circ}$ with respect to the primary beam and at a target to front face of phantom distance of $75 \mathrm{~cm}$. The precision long counter was at a complementary angle, at an effective target to detector distance of $100 \mathrm{~cm}$. Exposures using the deuterium target were done with the phantom at $0^{\circ}$ and a distance of $75 \mathrm{~cm}$, and the precision long counter positioned at $45^{\circ}$. Precision long counter data at $0^{\circ}$ and $45^{\circ}$ were used to establish the fluence at the phantom surface. 


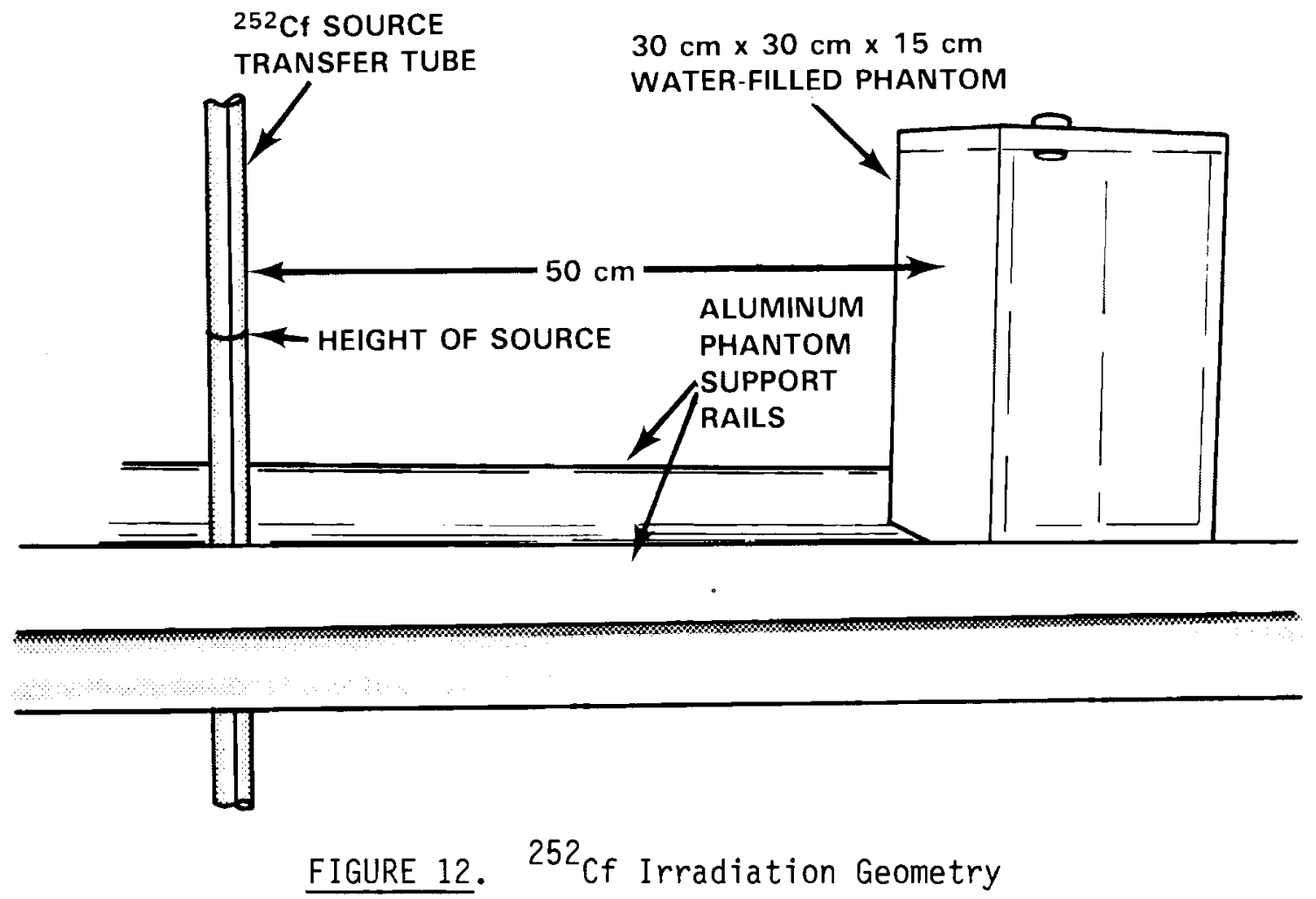

The phantoms were $30 \mathrm{~cm} \times 30 \mathrm{~cm} \times 16 \mathrm{~cm}$ lucite tanks with $0.64 \mathrm{~cm}$ thick walls, which were filled with water. The dosimeters were taped as close as possible to the center of the face of the phantom, and up to 6 dosimeters were irradiated at one time.

PNL ${ }^{252}$ Cf CALIBRATION TRACEABIL ITY

Traceability of the ${ }^{252} \mathrm{Cf}$ source is based on an NBS emission rate calibration. A conversion factor of $3.4 \times 10^{-8} \mathrm{rem}^{-\mathrm{cm}^{2}}$ (ANSI 1978) was used to convert to absorbed dose equivalent rate at the calibration point. The most recent accepted value is $3.33 \times 10^{-8}$ rem- $\mathrm{cm}^{-2}$ (Schwartz 1982). The ${ }^{252} \mathrm{Cf}$ source strength is corrected for decay according to a 2.65-year half life.

Correction to the dosimeter readings for neutrons scattered in the exposure facility were calculated using tabulated values developed by NBS (Schwartz 1982). The correction factors, expressed as a percent of the signal due to the unscattered or free-field neutrons for albedo dosimeters, at $50 \mathrm{~cm}$, 
were $0.8 \%$ (air scatter), $1.3 \%$ (source scatter), and $4.5 \%$ (room return), for a total of $6.5 \%$. The correction factors for dose equivalent totalled $1.3 \%$.

The room return correction for the albedo dosimeter was checked using laboratory evaluated thermoluminescent dosimeters. Groups of six dosimeters were irradiated at distances of $35 \mathrm{~cm}, 70 \mathrm{~cm}, 100 \mathrm{~cm}, 140 \mathrm{~cm}$, and $200 \mathrm{~cm}$ from the source. Each dosimeter contained ten tightly screened TLDs which were read manually. After background subtraction, dosimeter responses were corrected for sources and air scatter and normalized to a free field dose of 1000 mrem based on irradiation time.

We assumed that the fluence of room scattered neutrons was uniform over the central portion of the room (Schwartz 1982). Therefore, a plot of $D(r) r^{2}$ versus $r^{2}$ would be 1 inear, where $D(r)$ is the dosimeter response at distance $r$. A linear least squares fit to the data points was used to obtain a slope and intercept. The scatter correction in percent per square meter was obtained by dividing the slope by the intercept. The plot is shown in Figure 13 . The measured room return correction is $12 \% / \mathrm{m}^{2}$. Using this value the total scatter correction is $5.9 \%$, compared to the calculated results of $6.5 \%$.

The gamma component from the ${ }^{252} \mathrm{Cf}$ source was estimated from the TLD-700 response relative to a ${ }^{137} \mathrm{Cs}$ calibration. At $50 \mathrm{~cm}$, the penetrating gamma component was approximately $5 \%$ of the free-field neutron dose-equivalent rate.

\section{${ }^{252}$ Cf SOURCE DOSE CALCULATION}

Using the neutron emission rate determined at NBS, the free-field given dose is calculated by:

$$
H=\frac{N \cdot C_{N} \cdot t \cdot 3600}{4 \pi \cdot r^{2}}
$$

where $N=$ the neutron emission rate at the time of irradiation $(\mathrm{n} / \mathrm{sec})$. The source is decay corrected with a half 1 ife of $2.65 \mathrm{yr}$ $C_{N}=$ the dose-equivalent conversion factor $\left(\mathrm{mrem} / \mathrm{cm}^{2} / \mathrm{h}\right)$. The 1978 draft of ANSI 13.11 specifies $3.4 \times 10^{-5} \mathrm{mrem} / \mathrm{cm}^{2} / \mathrm{h}$. The present value is $3.33 \times 10^{-5} \mathrm{mrem} / \mathrm{m}^{2} / \mathrm{h}$ (Schwartz 1982) 


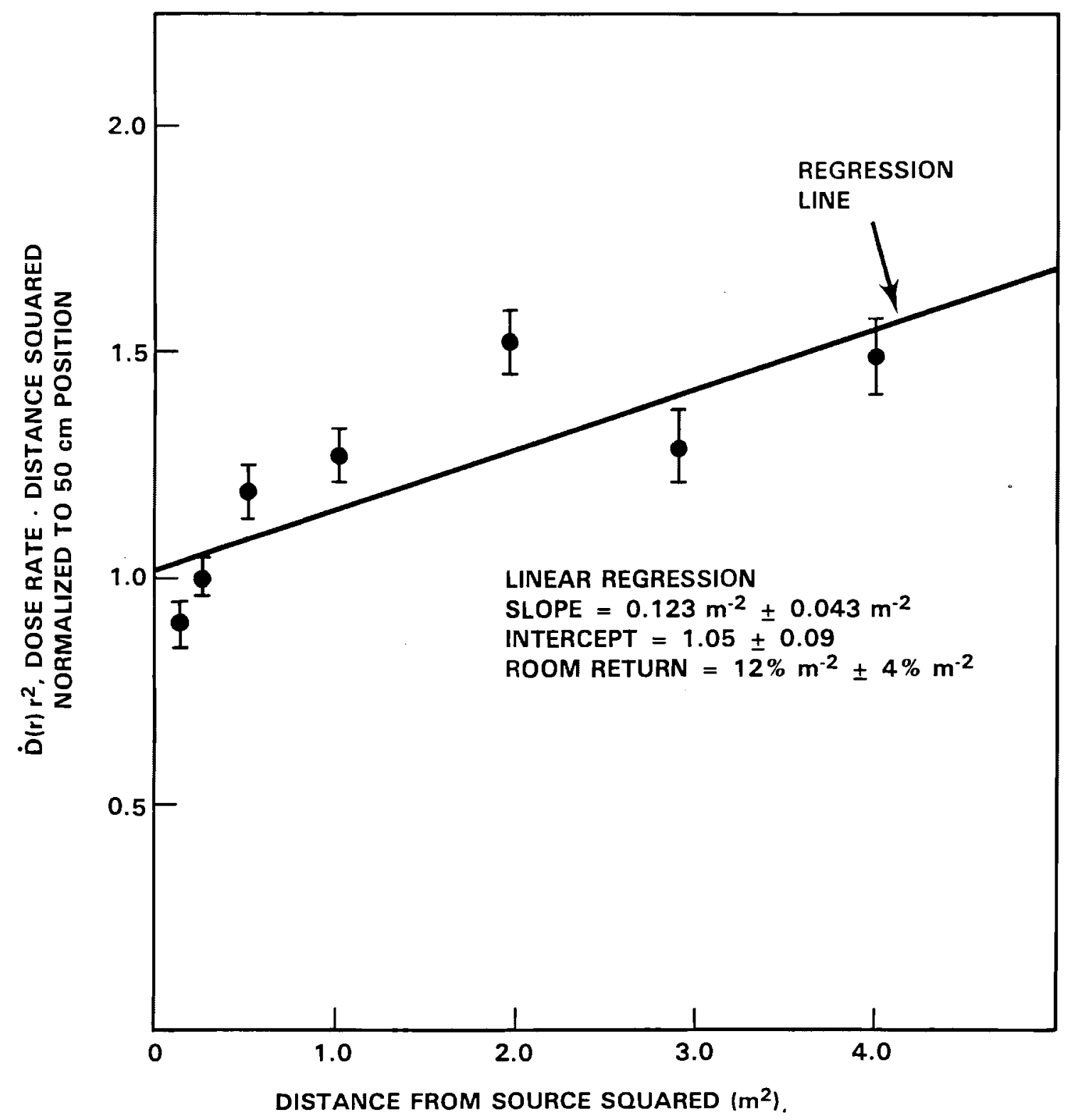

FIGURE 13. Room Return PNL Laboratory Dosimeter Using 1.1\% m Air Scatter 
$t=$ the irradiation time $(h)$.

$r=$ the distance from the source center to the calibration point $(\mathrm{cm})$.

Dosimeter and TEPC measurements for the high scatter geometry in the $3745 \mathrm{~A}$ building were initially performed at three distances from the source in several directions. Data for each distance were averaged. The measured room return was $19 \% / \mathrm{m}^{2}$ for the dosimeter and $18 \% / \mathrm{m}^{2}$ for the TEPC. Measurements were repeated with laboratory evaluated dosimeters placed along a single direction from the source. Linear regression for these seven distances showed significant scatter, and that the data are not homogeneous by direction. Thus, the averaging process may not be valid.

Room scatter determinations were also performed by PNL personnel at NBS for the unmoderated ${ }^{252} \mathrm{Cf}$ sources. A room return of $19 \% / \mathrm{m}^{2}$ was found for dosimeter measurements with the unmoderated source, the room return for the moderated source is significantly lower, approximately $6 \% / \mathrm{m}^{2}$. The TEPC response to scatter was a function of detector size, with the 5" TEPC yielding scatter factors of $7 \% / \mathrm{m}^{2}$ and $5 \% / \mathrm{m}^{2}$ respectively for the unmoderated and moderated sources. The 2-in. TEPC scatter factors were $5 \% / \mathrm{m}^{2}$ for both NBS sources.

Using the dosimeter measurements of room return, the tabulated air scatter values and the calculated source scatter terms, the total scatter correction at $50 \mathrm{~cm}$ was $6 \%$ for the PNL source in the 318 facility, $8 \%$ for the NBS unmoderated source, and 5\% for the NBS moderated sources. Dosimeter results were reduced by the appropriate scatter corrections to provide estimates of the "free field" response. 


\section{DATA ANALYSIS}

The analysis of personnel neutron dosimeter response is divided into four areas: 1) the accuracy and precision of dosimeters currently in use at DOE facilities when exposed to unknown doses of unmoderated ${ }^{252} \mathrm{Cf}$; 2) the accuracy and precision of the same dosimeters when calibration information is provided to the DOE contractors; 3) the lower detection limit of neutron dosimeters in current use; and 4) the energy dependence of dosimeters calibrated solely to unmoderated ${ }^{252} \mathrm{Cf}$. Results are reported in a strictly blind manner without identifying the participating laboratories. All data, including outliers, were used unless specifically flagged as bad by the contractor or by the irradiation facility. A compilation of data is contained in Appendix A.

\section{ACCURACY AND PRECISION}

The accuracy of dosimeter response is a measure of how close the reported dose is to the dose given. This will be defined as:

$$
b_{i}=\frac{R_{i}-G_{i}}{G_{i}}
$$

where $b_{i}$ is the accuracy or relative bias of the individual dosimeter response, $R_{i}$ is the reported dose, and $G_{j}$ is the given dose. The use of the relative bias as an estimator of accuracy is used instead of the bias alone so that irradiations at various dose levels can be readily compared.

All irradiations were performed in replicate according to the schedule of Table 3. To evaluate the accuracy of $n$ dosimeters irradiated at the same dose we use:

$$
B=\frac{1}{n} \sum_{i=1}^{n} b_{i}
$$

where $B$ is the mean relative bias or accuracy at a given dose level and $b_{i}$ is defined in equation (1). Since we are dealing with the relative bias, equation (2) can also be used to estimate accuracy over all dose levels. 
TABLE 3. Number of Neutron Dosimeter Irradiations by Month, Radiation Type and Exposure Level

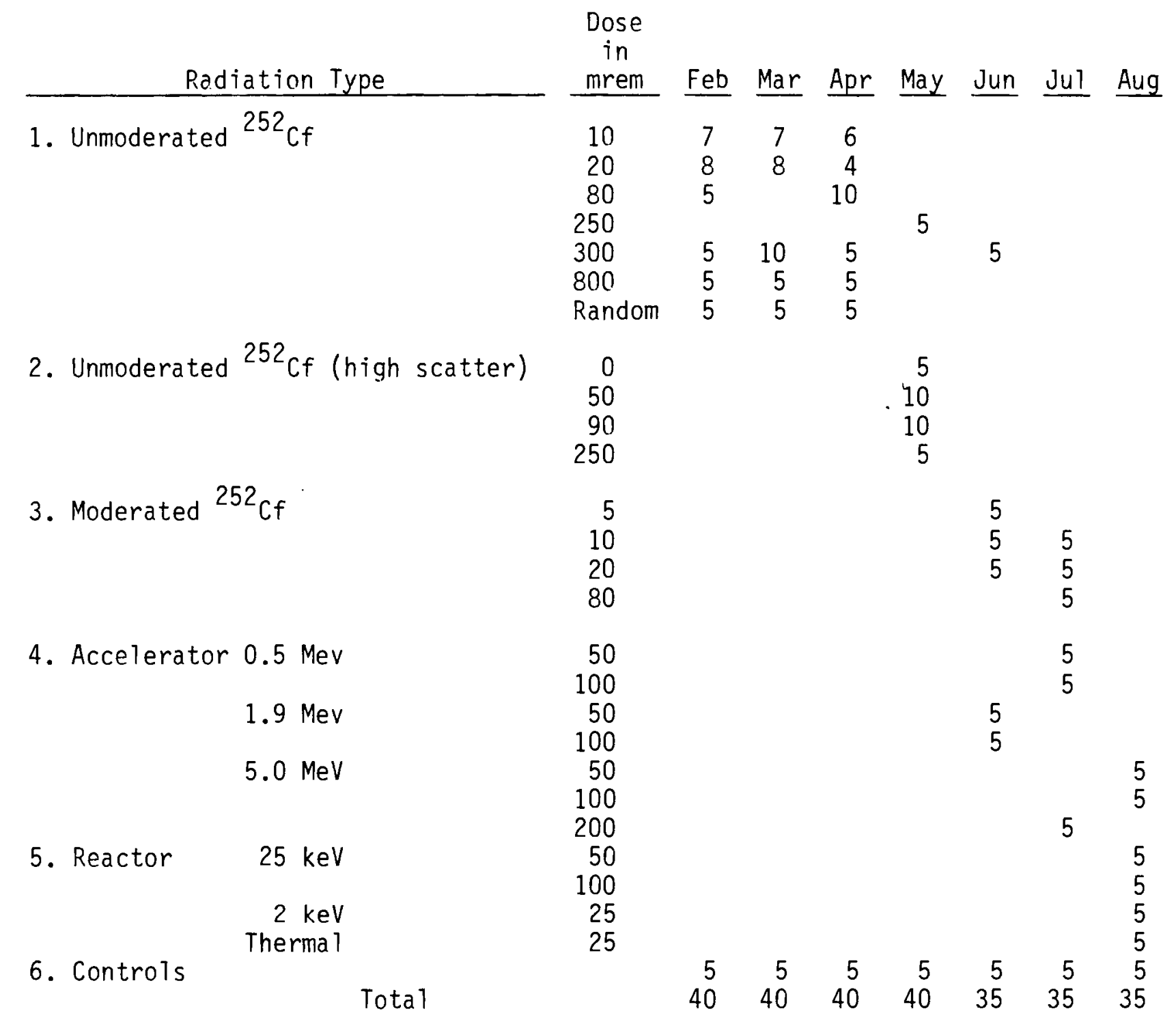


Precision of dosimeter response or repeatability is measured by the coefficient of variation, CV. This statistical estimator is defined as:

$$
C V=S / \bar{R}
$$

where $S$ is the standard deviation of each group of dosimeters and $\bar{R}$ is the mean reported dose. It expresses variation in reproducibility relative to the magnitude of the dose reported and is independent of the bias. This statistical estimator permits comparisons of precision between contractors even though their accuracies may differ. To calculate the estimated precision at a given dose, we use:

$$
P_{D}=C V \cdot D
$$

where $P_{D}$ is the estimated precision at a given dose, $D$, and $C V$ is taken from the best estimate or closest mean to that dose.

Phase 1

Phase 1 of the personnel neutron dosimeter response study involved irradiations for the months of February, March, and April (see Table 3). The participating DOE contractors were asked to use their own calibrations. The dosimeter response measured by accuracy and precision is graphically represented in Figures 14 and 15. A large variation in accuracy is seen particularly at the lower exposure levels. The range of accuracies at 10 mrem is from -1.71 to +2.31 and is accompanied by a large coefficient of variation ( $52 \%$ of the dose). The higher doses, particularly the $800 \mathrm{mrem}$, show a much narrower range $(-0.66$ to +0.08$)$ with most contractors underestimating the given value.

A specific problem was encountered with the data from one contractor. Contractor I reported absolute biases of 2.31 and 1.32 at 10 and 20 mrem, respectively. These are based on only March data, and appear as obvious outliers. Data for the other months was lost due to dosimeter fading as dosimeters were not given adequate dessicant.

Overall Phase 1 results indicate a 20-30\% underestimate of dose by most DOE contractors. Further, the precision at low doses averages approximately $100 \%$ of the dose given, indicating difficulty in detecting 10 and 20 mrem neutron doses. 
ACCURACY

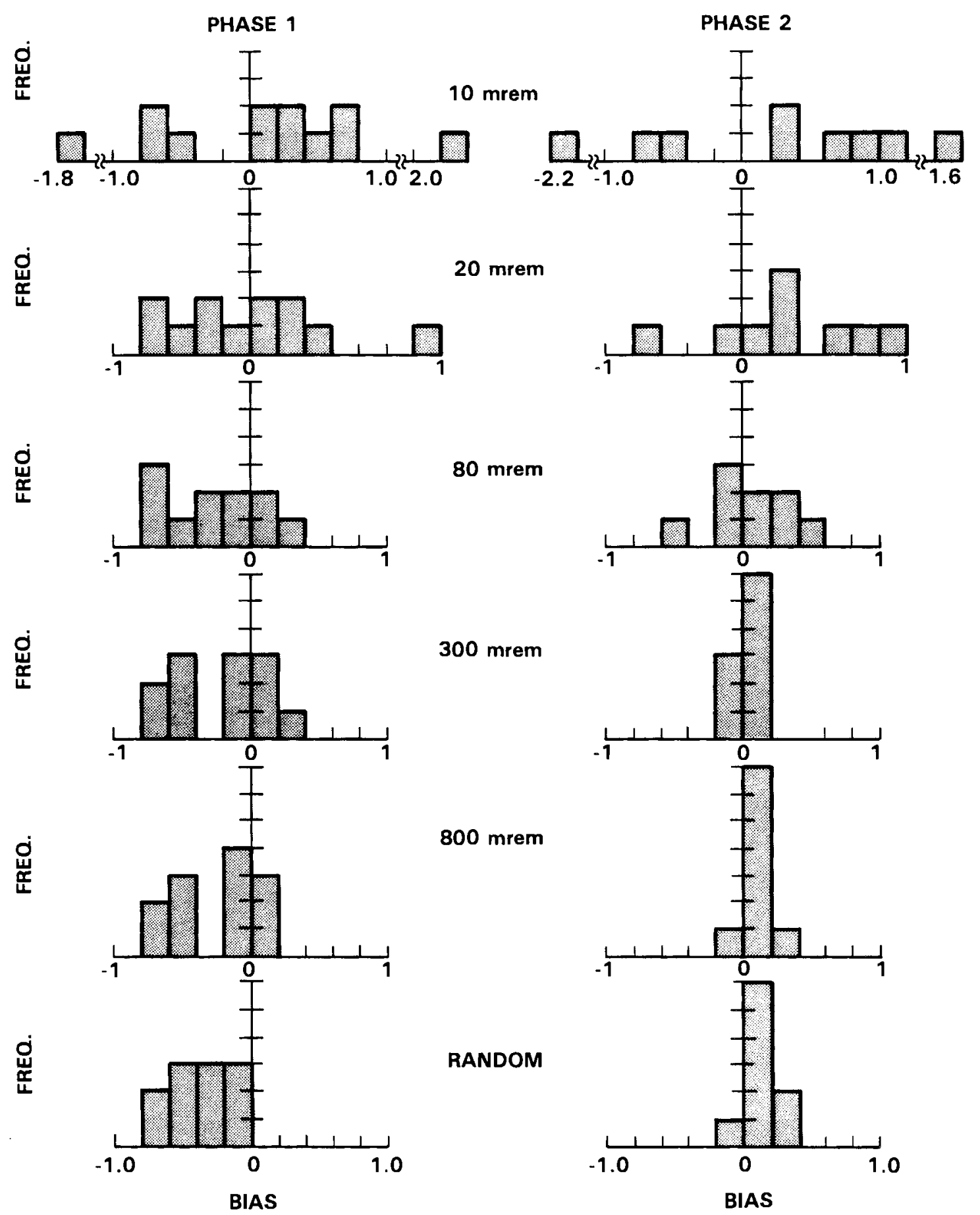

FIGURE 14. Bias for Various Dose Levels for Phase 1 and Phase 2 
PRECISION

PHASE 1

PHASE 2
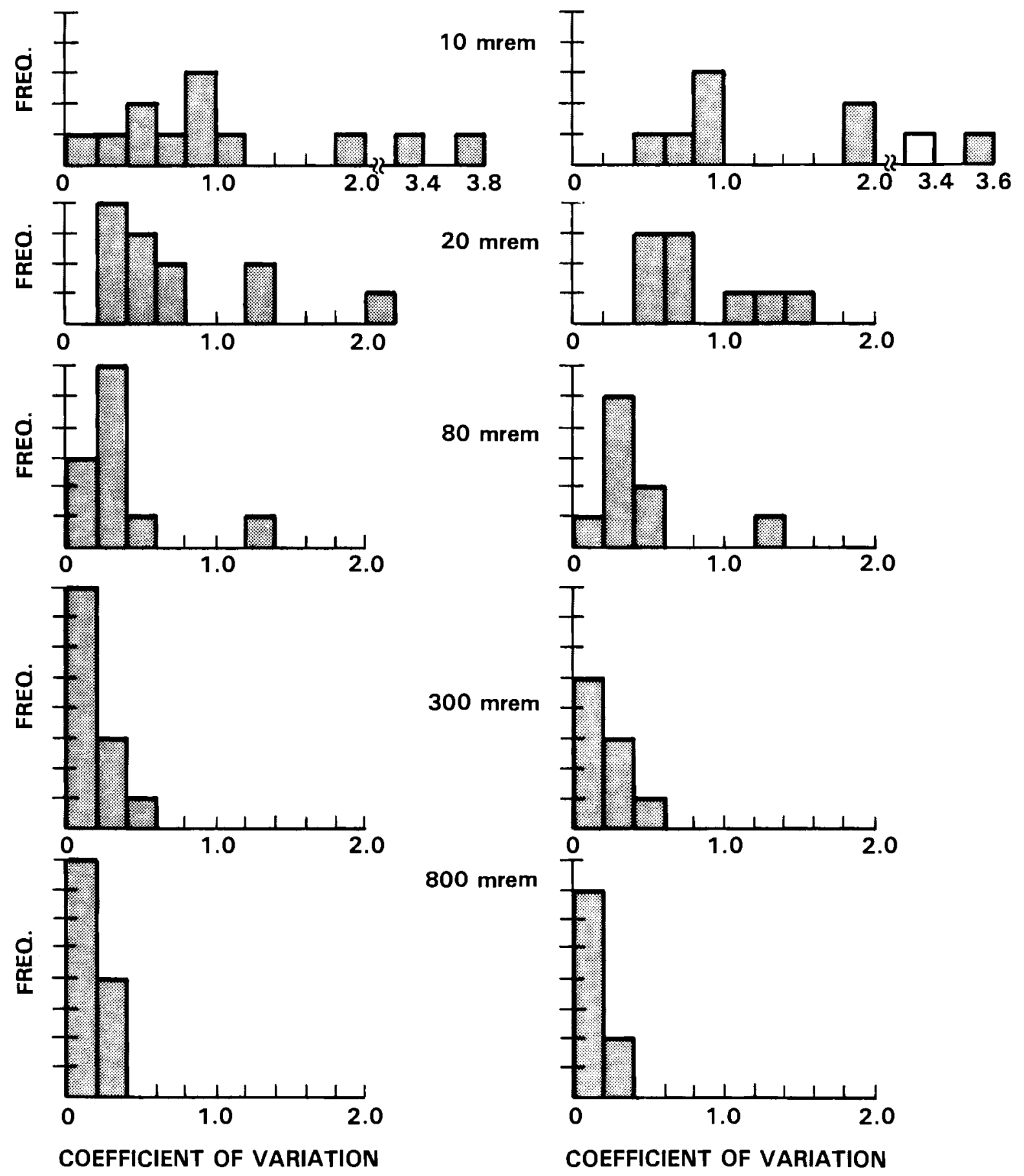

FIGURE 15. Precision for Various Dose Levels for Phase 1 and Phase 2 
Phase 2

The DOE contractors were provided with uniform calibration information for the second part of the dosimeter study. This information included the type of neutron source, the irradiation parameters (room size, phantom description, source location) and the identity of a 11 control (0 mrem) and 300 mrem irradiated dosimeters for the months of February, March, and April. Also included were controls and 250 mrem irradiated dosimeters for the month of May. Using this information, all contractors were requested to recalculate the dosimeter response of Phase 1 irradiations. Three contractors failed to provide the recalculated data, contractors $I, J$, and $K$, and Phase 2 results reflect a summary of the other 9 contractors.

Figures 14 and 15 indicate the accuracy and precision of Phase 2 results. A noticeable improvement is seen in accuracy after recalibration. Again the wide spread of accuracy is seen at the lower dose levels with a very narrow range at the higher doses. The average accuracy for all contractors for all dose levels is 0.11 with most of this positive absolute bias attributed to the 10 and 20 mrem irradiations. The 80,300 , and 800 mrem doses are within $5 \%$ of the given value. Figure 16 demonstrates the dramatic effect of recalibration on accuracy. Precision remains essentially the same for Phases 1 and 2 as would be expected. There is a small improvement seen at the higher irradiation levels (see Figure 17). If we restrict ourselves to irradiations above 50 mrem, most contractors have both accuracies and precisions below 0.20 .

\section{LOWER DETECTION LIMIT}

A very useful parameter in defining neutron dosimeter response is the minimum irradiation level that a set of dosimeters can reliability detect. This detection point has been called by different names but for our purposes will be called the lower detection limit $\left(L_{D}\right)$. This will be defined as

$$
L_{D}=K_{\alpha} \sigma_{0}+K_{B} \sigma_{D}
$$

where $L_{D}$ is the lower detection 1 imit of a contractor's dosimeter system, $K_{\alpha}$ and $K_{\beta}$ are the abscisses of the standardized normal distribution corresponding to the probability levels $1-\alpha$ and $1-\beta$, respectively $\sigma_{0}$ is the 
ACCURACY

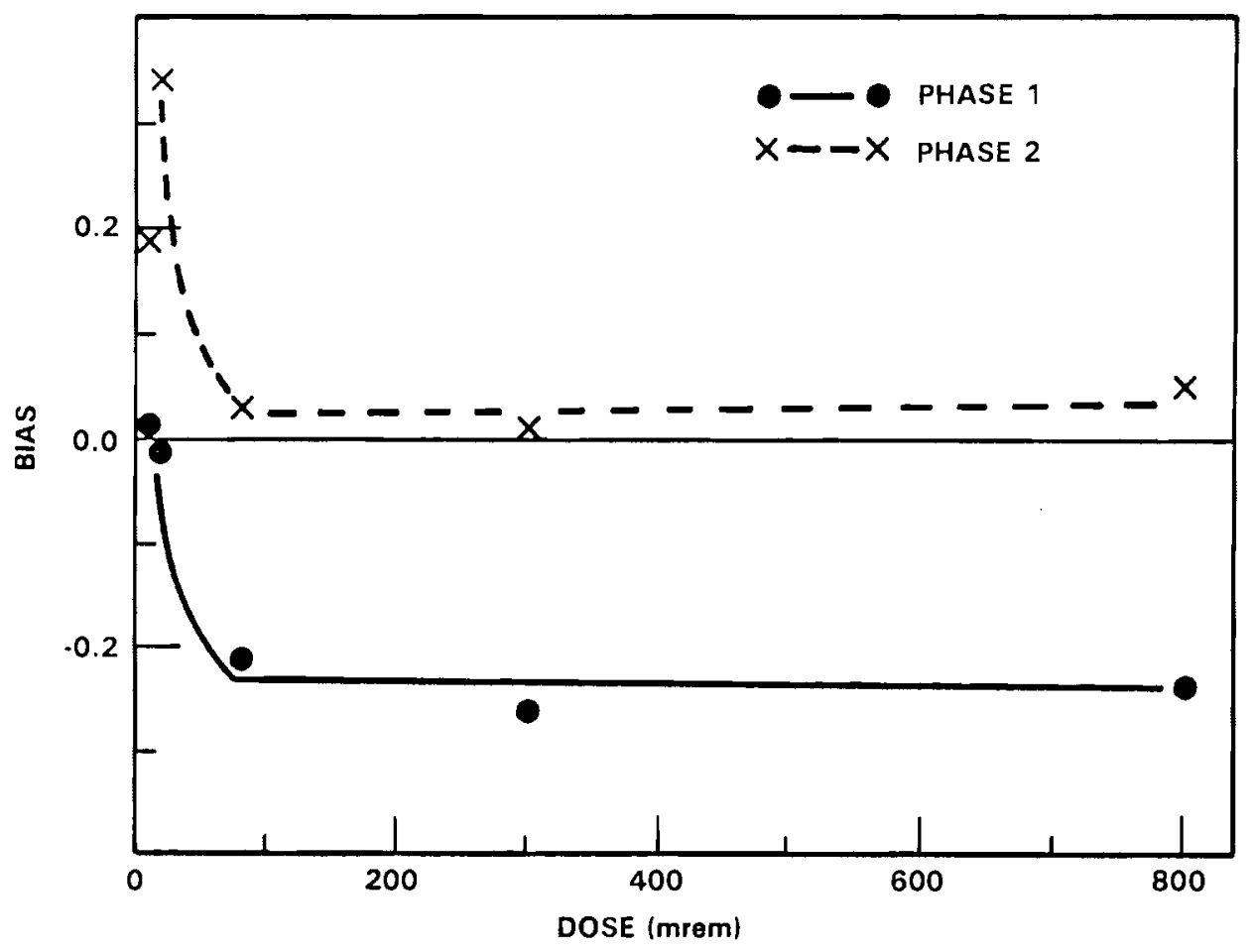

FIGURE 16. Plot of Accuracy for Phase 1 and Phase 2 Data

\section{PRECISION}

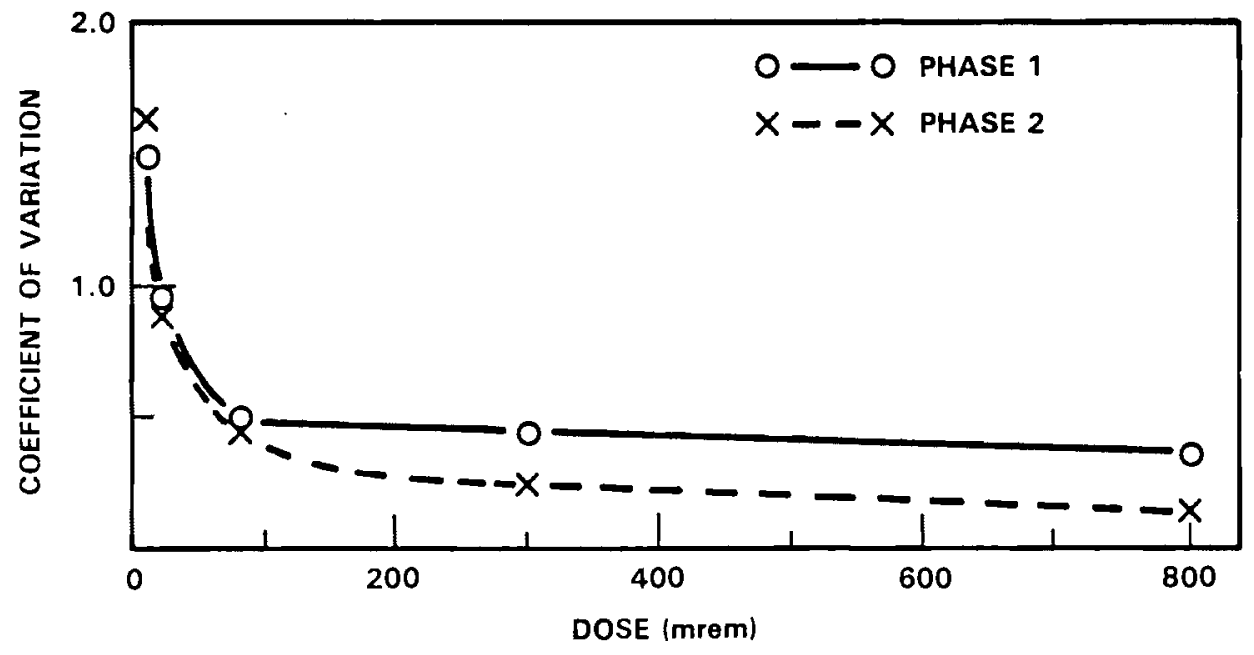

FIGURE 17. Plot of Precision for Phase 1 and Phase 2 Data 
standard deviation of controls and $\alpha_{D}$ is the standard deviation at the detection limit. The values for $\alpha$ and $B$ are the desired probability levels for false positive and false negative results (type 1 and type 2 errors) that are acceptable. Commonly these are set equal and chosen to be 5,10 , or $20 \%$. A further discussion of equation (5) is found in an article by Curie (1968).

To estimate the lower detection 1 imit requires the value of $\sigma_{0}$ or the standard deviation. The data provided by the control dosimeters in this study were not always reliable because negative results were often reported as zeros and the relatively small number of dosimeters make estimating the standard deviation difficult. Regression analysis of the data often yielded intercepts very different from mean control values, although the linearity and correlation of fit were extremely good. Estimates of the standard deviation for control dosimeters and 10 mrem irradiated dosimeters were used to determine a suitable value for $\sigma_{0}$ for each of the contractors.

Figure 18 summarizes the lower detection 1 imits for a 11 contractors assuming acceptible errors of 5, 10 and 20\%, both $\alpha$ and $\beta$ being equal. Most contractors have a lower detection limit between 20 and 50 mrem (using a $10 \%$ acceptible error). Two contractors, $C$ and $J$, are able to distinguish the 20 mrem irradiations from background. On the other extreme, contractors $E$ and $\mathrm{L}$ can do no better than 130 and $210 \mathrm{mrem}$, respectively. Overall, the average lower detection limit is 50 mrem at the $10 \%$ acceptable error level.

\section{Phase 3 - Energy Dependence}

During the months of May, June, July, and August the neutron dosimeter study focused on the energy dependence of dosimeter response. During May, dosimeters were irradiated to unmoderated ${ }^{252} \mathrm{Cf}$ in a smaller irradiation facility where the scatter was increased. Control or 0 mrem irradiated dosimeters were included for both the high scatter environment and the normal low scatter storage area. Also dosimeters irradiated to $250 \mathrm{mrem}$ in the PNL low scatter facility were provided for comparison. Figure 19 summarizes this data and indicates an average over-response of approximately $35 \%$ in the high scatter environment. This agrees with long counter and tissue equivalent proportional counter measurements made in the high-scatter facility, indicating the effect of room size on dosimeter response. 


\section{MINIMUM DETECTION LIMIT}

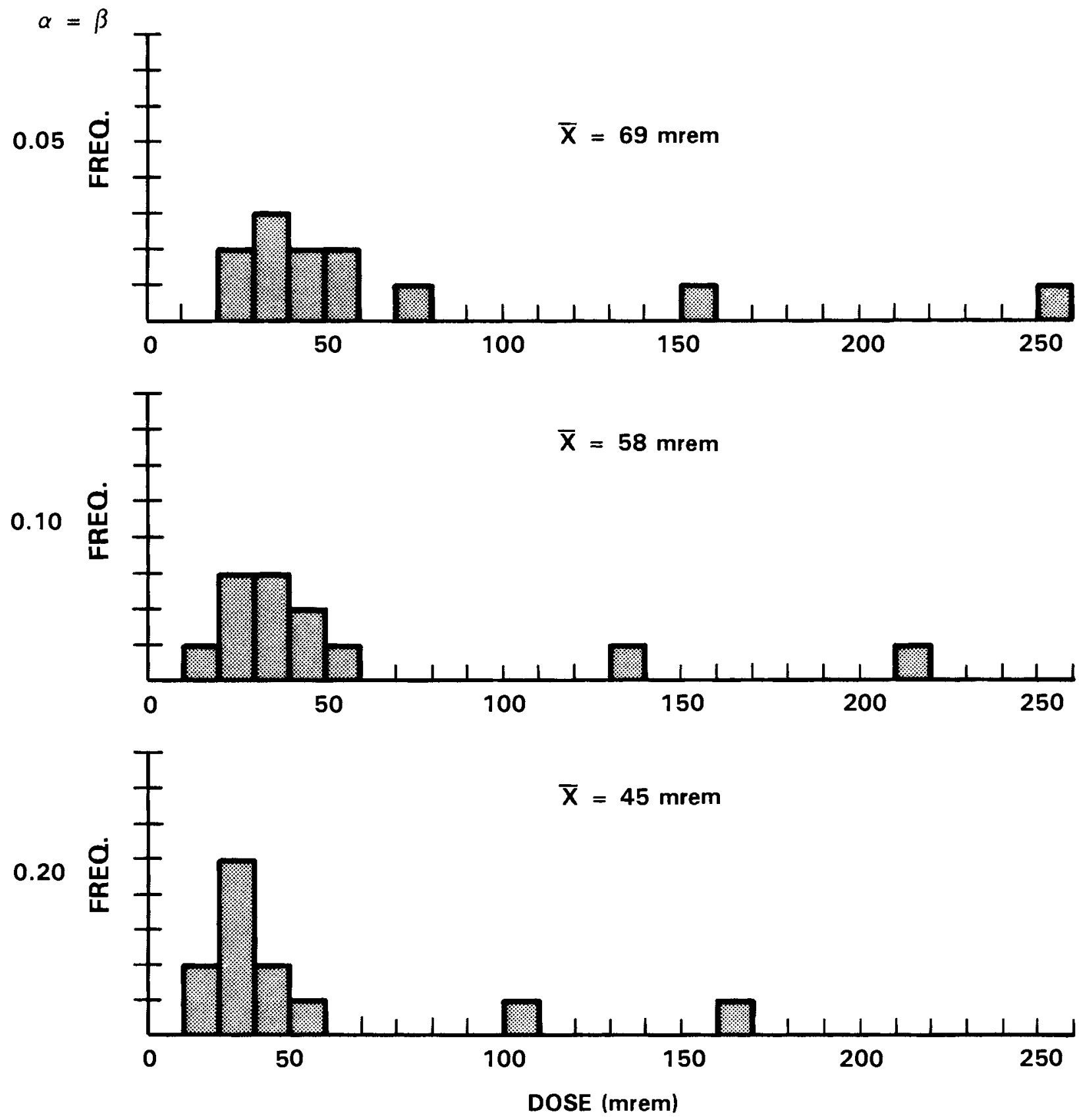

FIGURE 18. Histogram of Estimated Lower Detection Limits for All Contractors at 3 Levels of Acceptable Error, 5\%, 10\% and $20 \%(\alpha=\beta)$ 
HIGH SCATTER VS LOW SCATTER Cf-252

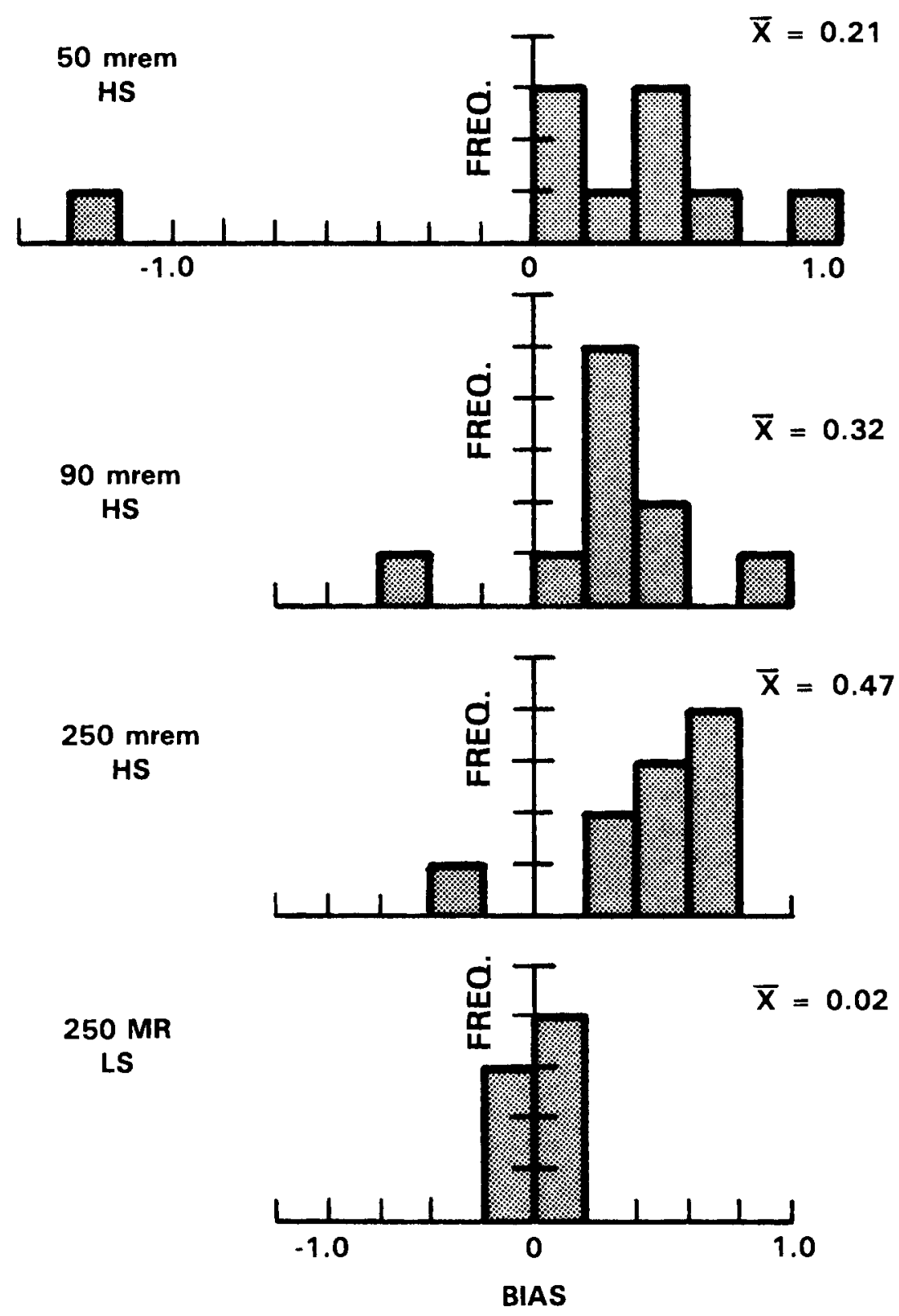

FIGURE 19. Histogram of Neutron Dosimeter Response in a High Scatter Environment (HS) Compared to a Low Scatter Environment (LS) 
Dosimeters were irradiated by moderated ${ }^{252} \mathrm{Cf}$ at NBS during June and July. Figure 20 shows the large over-response of dosimeters, which were calibrated to the higher energy bare ${ }^{252} \mathrm{Cf}$, at irradiation levels of 5,10 , 20 , and $80 \mathrm{mrem}$. This over-response is consistent at about $1120 \%$ of the dose.

Accelerator irradations at energies of $0.5,1.9$, and $5.0 \mathrm{MeV}$ were also done during Phase 3. Results are summarized in Figure 21. Here we see a $100 \%$ over-response at the low energy, a slight over-response at $1.9 \mathrm{MeV}$ (an energy similar to the unmoderated ${ }^{252} \mathrm{Cf}$ used for calibration) and a $64 \%$ under-response at the high energy.

Reactor irradiations at very low energies of $25 \mathrm{keV}, 2 \mathrm{keV}$ and thermal neutrons show very large over-responses (see Figure 22). The $25 \mathrm{keV}$ response averages $3800 \%$ of the dose, the $2 \mathrm{keV}$ is $10,900 \%$ and the therma 1 is $11,600 \%$. Clearly when evaluating neutron dosimeter response it is necessary to know the energy spectrum or field to which the dosimeters are exposed, and to calibrate them appropriately. 
PHASE 3 ACCURACY

MODERATED Cf-252

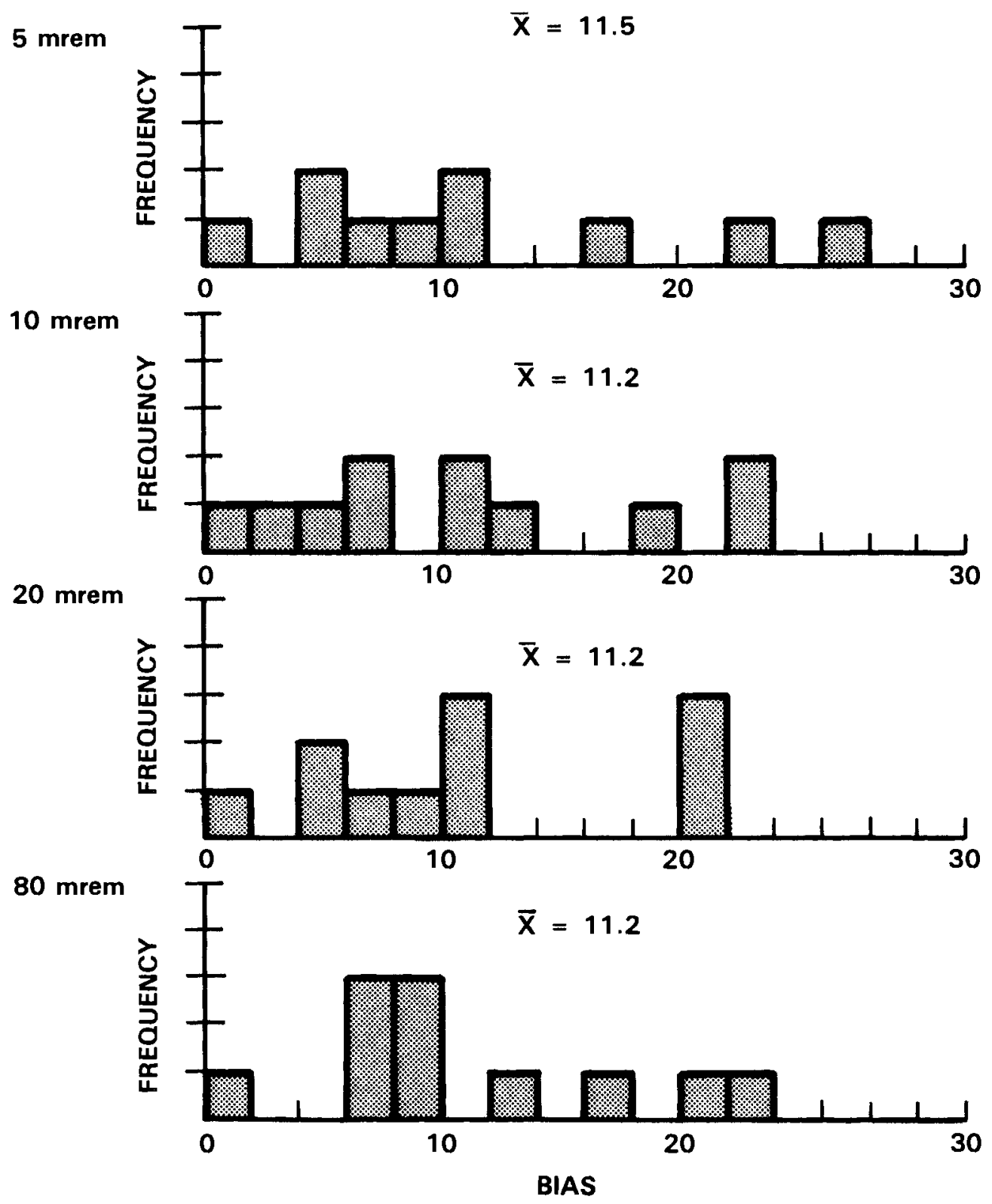

FIGURE 20. Histograms of the Accuracy of Neutron Dosimeter Response During Phase 3 Irradiations to Moderated $252 \mathrm{Cf}$ by Irradiation Leve1 
PHASE 3 ACCURACY

ACCELERATOR-PRODUCED NEUTRONS

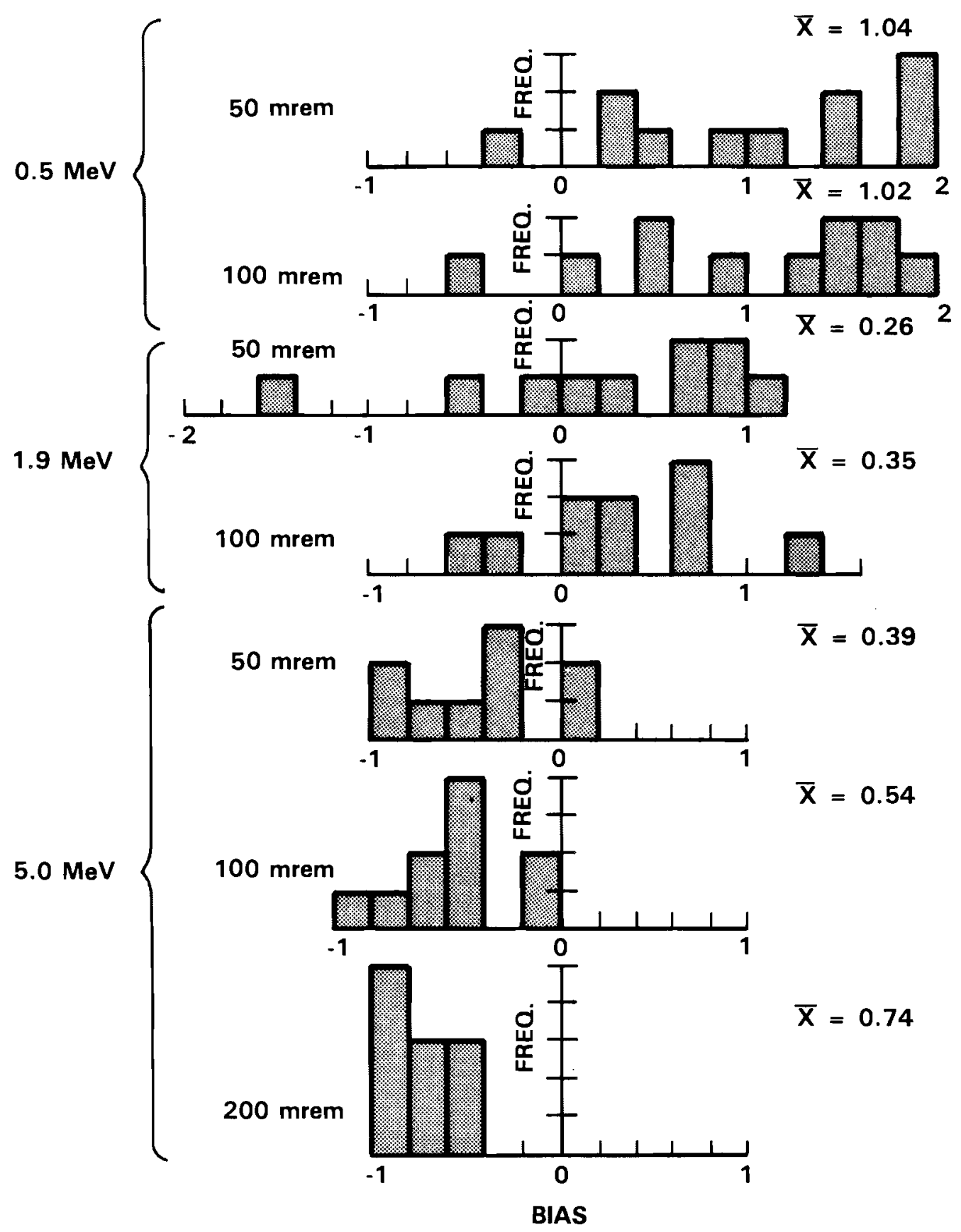

FIGURE 21. Histograms of the Accuracy of Neutron Dosimeter Response to the Three Energies of Monoenergetic Neutrons 


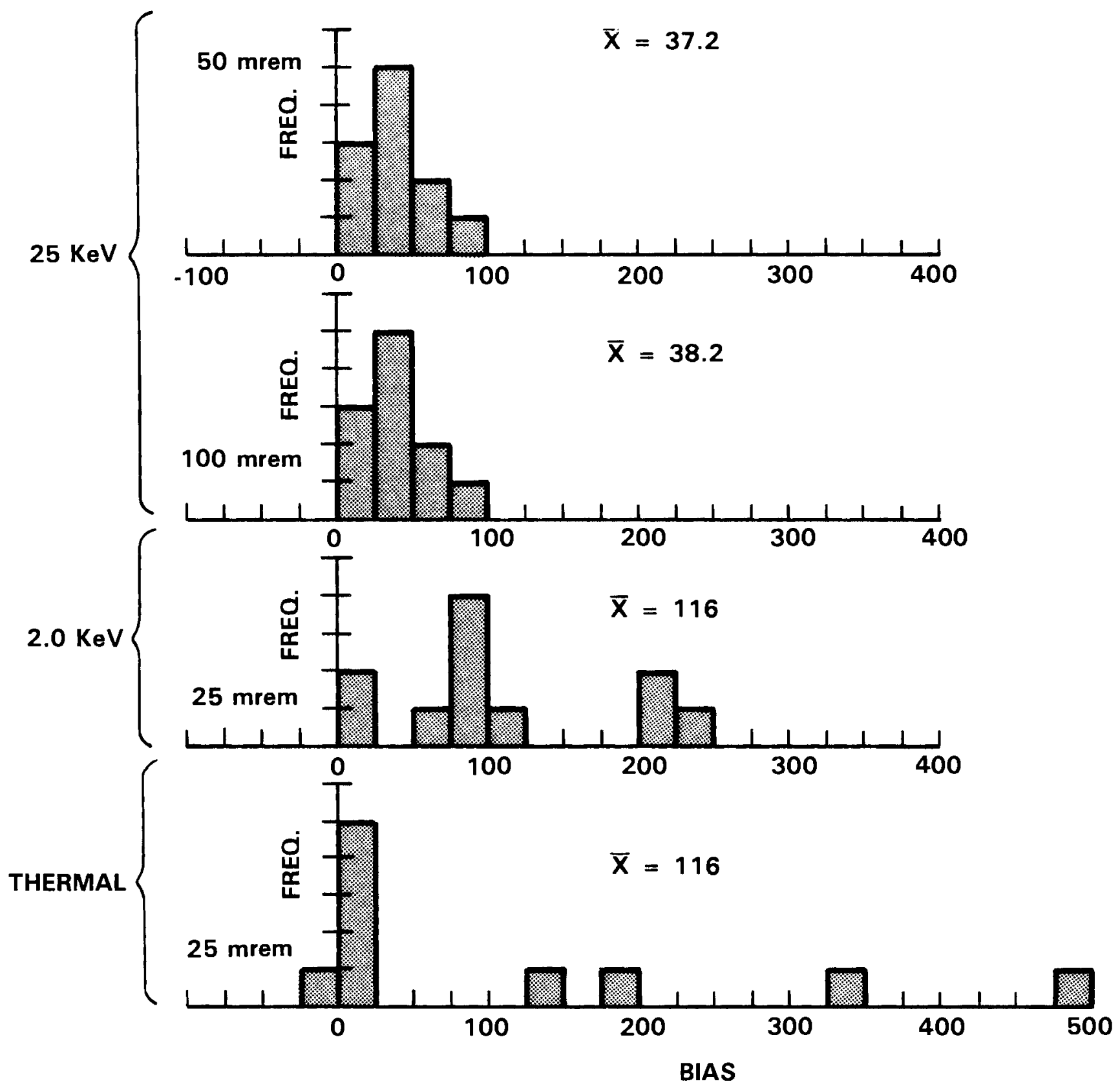

FIGURE 22. Histograms of the Accuracy of Neutron Dosimeter Response to Various Energies of Reactor Beams 


\section{DISCUSSION}

Some of the characteristics which may have influenced dosimeter performance include: design and construction; calibration and dose determination procedures; and processing and handling techniques. It is difficult to identify which of these items affected performance in terms of accuracy, precision, lower-limit detection or energy response. This study was not specifically designed to answer these questions. In order to do so, a much more specific set of tests would have to be designed to isolate the influence of each potential source of uncertainty. This could, however, be the subject of future investigations.

In general, there was little observable difference between the design and construction details of good and poor performance dosimeters. Nearly all of the designs tested were TLD-albedo dosimeters with either complete cadmium shielding (Hankins-type) or front and back (asymmetric) cadmium shielding. No systematic difference in performance could be found between these designs.

The dose determination procedures and processing methods were all quite similar, although some small differences in dose algorithms were reported. This situation seems, therefore, unlikely to be a major contributing factor to large differences in performance.

Some of the laboratories having good accuracy and precision during this study reported the use of a single set of dosimeters throughout. This procedure would probably enable closer tracking of individual dosimeter response characteristics and thereby enhance precision and possibly accuracy. However, this handling proceucre may not be practical in the situation where large numbers of dosimeters are processed.

The calibration situations at each participating laboratory were sufficiently different to warrant consideration as a potential source of uncertainty, but there is insufficient data in this report to reach a firm conclusion. It can only be noted that when all participants used a common calibration during Phase 2 of this project, then the overall accuracy was generally improved. The details of calibration methods and sources would be a useful area for future study. 


\section{REFERENCES}

American National Standards Institute (ANSI). 1978. Draft American National Standard, Criteria for Testing Personnel Dosimetry Performance. ANSI N13.11. New York.

American National Standards Institute (ANSI). 1982. Draft American National Standard, Criteria for Testing Personnel Dosimetry Performance. ANSI N13.11-1982. New York.

Aldrich, T. 1981. Study 4 in Hanford Personnel Dosimeter Supporting Studies FY-1981. PNL-3536, Pacific Northwest Laboratory, Richiand, Washington.

Brackenbush, L. W. 1980. Personnel Neutron Dosimetry at Department of Energy Facilities. PNL-3213, Pacific Northwest Laboratory, Richland, Washington.

Curie, L. A. 1968. "Limits for Qualitative Detection and Quantitative Determination." Analytical Chemistry, 40, 586-593.

Dudley, R. A. 1966. "Dosimetry With Photographic Emulsions." In Radiation Dosimetry. F. H. Attix, W. C. Roesch and E. Tochilin, eds. Academic Press, New York.

Grund1, J., and C. Eisenhauer. 1975. "Fission-Rate Measurements for Materials and Neutron Dosimetry in Reactor Environments." Proceedings of the First Symposium on Reactor Dosimetry. Vol. 1, page 425. Petter, Holland.

Piesch, E., and Burgkhardt. 1978. "Advances in Albedo Neutron Dosimetry." In Advances in Radiation Protection Monitoring. IAEA-SM-229/5, International Atomic Energy Agency, Vienna, Austria.

Schwartz, R. B. 1977. Calibration and Use of Filtered Beams. NBS Special Publication 493, U.S. Department of Commerce, National Bureau of Standards, Washington, D.C.

Schwartz, R. B., and C. M. Eisenhauer. 1980. The Design and Contruction of a $\mathrm{D}_{2} \mathrm{O}$-Moderated $\mathrm{Cf}$ Source for Calibrating Neutron Personnel Dosimeters Used at Nuclear Power Reactors. NUREG/CR-1204, U.S. Nuclear Regulatory Commission, Washington, D.C.

Schwartz, R. B., and C. M. Eisenhauer. 1982. Procedures for Calibrating Neutron Personnel Dosimeters. NBS Special Publication 633, U.S. Department of Commerce, Nationa? Bureau of Standards, Washington, D.C. 
APPENDIX A

PARTICIPANT DATA 
TABLE A.1. Means and Standard Deviations (SD) of Phase 1 Neutron Dosimeter Response Reported by Contractor and Irradiation Level. A11 results are reported in mrem. Total Mean and SD includes all dosimeters irradiated during Phase 1. Response for contractor I is based on March data only, the other month's dosimeters faded due to lack of constant desicant.

\begin{tabular}{|c|c|c|c|c|c|c|c|}
\hline \multicolumn{2}{|c|}{ Contractor } & CONTFOL & $10 \mathrm{MF}$ & $20 \mathrm{MF}$ & BO MF & $300 \mathrm{MF}$ & $300 \mathrm{MF}$ \\
\hline A & $\begin{array}{l}\text { MEAN } \\
\text { SD }\end{array}$ & 0.0 & $\begin{array}{l}17.5 \\
14.0\end{array}$ & $\begin{array}{l}27.5 \\
20.6\end{array}$ & $\begin{array}{r}102.0 \\
22.0\end{array}$ & $\begin{array}{r}31 A .4 \\
39.5\end{array}$ & $\begin{array}{r}867.2 \\
75.2\end{array}$ \\
\hline$E$ & $\begin{array}{l}\text { MEAN } \\
\text { SD }\end{array}$ & $\begin{array}{r}-0.4 \\
1.1\end{array}$ & $\begin{array}{l}2.9 \\
9.7\end{array}$ & $\begin{array}{l}5.9 \\
8.2\end{array}$ & $\begin{array}{l}67.7 \\
16.6\end{array}$ & $\begin{array}{r}275.5 \\
28.1\end{array}$ & $\begin{array}{r}750.4 \\
52.7\end{array}$ \\
\hline C & $\begin{array}{l}\text { MEAN } \\
\text { SD }\end{array}$ & $\begin{array}{r}-0.1 \\
1.3\end{array}$ & $\begin{array}{r}11.4 \\
5.5\end{array}$ & $\begin{array}{l}25.4 \\
1 \leq .7\end{array}$ & $\begin{array}{l}89.9 \\
10.6\end{array}$ & $\begin{array}{r}305.5 \\
44.7\end{array}$ & $\begin{array}{r}81.4 .7 \\
36.4\end{array}$ \\
\hline[ & $\begin{array}{l}\text { MEAN } \\
\text { SD }\end{array}$ & 0.0 & $\begin{array}{l}13.6 \\
12.9\end{array}$ & $\begin{array}{l}21.7 \\
16.2\end{array}$ & $\begin{array}{l}60.0 \\
16.1\end{array}$ & $\begin{array}{r}155.0 \\
22.0\end{array}$ & $\begin{array}{r}435.5 \\
59.1\end{array}$ \\
\hline$E$ & $\begin{array}{l}\text { MEAN } \\
\text { SD }\end{array}$ & $\begin{array}{r}5.0 \\
12.4\end{array}$ & $\begin{array}{l}12.7 \\
22.8\end{array}$ & $\begin{array}{l}18.5 \\
24.6\end{array}$ & $\begin{array}{l}5.8 \\
30.7\end{array}$ & $\begin{array}{r}122.5 \\
49.9\end{array}$ & $\begin{array}{l}424.5 \\
16.5 .2\end{array}$ \\
\hline$F$ & $\begin{array}{l}\text { MEAN } \\
S D\end{array}$ & $\begin{array}{l}1.3 \\
2.2\end{array}$ & $\begin{array}{l}4.2 \\
4.6\end{array}$ & $\begin{array}{l}7.3 \\
5.4\end{array}$ & $\begin{array}{r}30.2 \\
6.4\end{array}$ & $\begin{array}{r}105.1 \\
28.6\end{array}$ & $\begin{array}{r}282.5 \\
85.7\end{array}$ \\
\hline$g$ & $\begin{array}{l}\text { MEAN } \\
\text { SD }\end{array}$ & $\begin{array}{l}4.0 \\
2.4\end{array}$ & $\begin{array}{r}10.0 \\
3.2\end{array}$ & $\begin{array}{r}15.8 \\
4.9\end{array}$ & $\begin{array}{r}44.7 \\
7.8\end{array}$ & $\begin{array}{r}156.7 \\
25.1\end{array}$ & $\begin{array}{r}405.9 \\
79.5\end{array}$ \\
\hline$H$ & $\begin{array}{l}\text { MEAN } \\
\text { SD }\end{array}$ & $\begin{array}{l}1.5 \\
9.5\end{array}$ & $\begin{array}{l}14.9 \\
11.4\end{array}$ & $\begin{array}{l}28.6 \\
15.8\end{array}$ & $\begin{array}{l}74.4 \\
19.1\end{array}$ & $\begin{array}{r}257.5 \\
54.1\end{array}$ & $\begin{array}{l}692.7 \\
145.1\end{array}$ \\
\hline I & $\begin{array}{l}\text { MEAN } \\
\text { SD }\end{array}$ & $\begin{array}{r}12.8 \\
7.1\end{array}$ & $\begin{array}{l}3.1 \\
17.0\end{array}$ & $\begin{array}{l}46.4 \\
15.2\end{array}$ & -- & $\begin{array}{r}401.0 \\
58.0\end{array}$ & $\begin{array}{r}774.4 \\
55.0\end{array}$ \\
\hline$J$ & $\begin{array}{l}\text { MEAN } \\
\text { SD }\end{array}$ & $\begin{array}{l}0.4 \\
1.7\end{array}$ & $\begin{array}{l}3.3 \\
2.9\end{array}$ & $\begin{array}{l}8.0 \\
2.9\end{array}$ & $\begin{array}{r}26.6 \\
6.7\end{array}$ & $\begin{array}{l}95.1 \\
13.3\end{array}$ & $\begin{array}{r}271.5 \\
26.2\end{array}$ \\
\hline$r$ & $\begin{array}{l}\text { MEAN } \\
\text { SD }\end{array}$ & $\begin{array}{l}0.6 \\
8.5\end{array}$ & $\begin{array}{r}15.9 \\
3.1\end{array}$ & $\begin{array}{r}27.7 \\
5.7\end{array}$ & $\begin{array}{r}82.6 \\
9.6\end{array}$ & $\begin{array}{r}29.5 .4 \\
34.5\end{array}$ & $\begin{array}{r}768.7 \\
78.2\end{array}$ \\
\hline$L$ & $\begin{array}{l}\text { MEAN } \\
\text { SD }\end{array}$ & $\begin{array}{l}-0.2 \\
29.2\end{array}$ & $\begin{array}{l}-7.1 \\
25.7\end{array}$ & $\begin{array}{l}15.7 \\
32.4\end{array}$ & $\begin{array}{l}27.9 \\
35.2\end{array}$ & $\begin{array}{r}250.2 \\
86.5\end{array}$ & $\begin{array}{l}722.2 \\
125.6\end{array}$ \\
\hline TOTAL & $\begin{array}{l}\text { MEAN } \\
\text { SD }\end{array}$ & $\begin{array}{r}1.3 \\
10.2\end{array}$ & $\begin{array}{l}10.1 \\
15.4\end{array}$ & $\begin{array}{l}19.6 \\
18.4\end{array}$ & $\begin{array}{l}62.4 \\
30.6\end{array}$ & $\begin{array}{r}222.8 \\
97.4\end{array}$ & $\begin{array}{l}605.9 \\
225.0\end{array}$ \\
\hline
\end{tabular}


TABLE A.2. Mean and Standard Deviation Summary of February Data, Phase 1. Contractor $\mathrm{J}$ did not participate this month and I experienced dosimeter fading. Total Mean is the average neutron dosimeter response for all contractors.

\begin{tabular}{|c|c|c|c|c|c|c|c|}
\hline \multicolumn{2}{|c|}{ Contractor } & CONTFIOL & $10 \mathrm{MF}$ & $20 \mathrm{MF}$ & go MF: & $30 \mathrm{MF}$ & $300 \mathrm{MF}$ \\
\hline A & $\begin{array}{l}\text { MEAN } \\
\text { SD }\end{array}$ & 0.0 & $\begin{array}{l}15.7 \\
18.5\end{array}$ & $\begin{array}{l}30.4 \\
24.6\end{array}$ & $\begin{array}{l}97.0 \\
10.0\end{array}$ & $\begin{array}{r}12.9 \\
24.2\end{array}$ & $\begin{array}{r}800.2 \\
46.8\end{array}$ \\
\hline E & $\begin{array}{l}\text { MEAN } \\
\text { SD }\end{array}$ & 0.0 & 0.0 & $\begin{array}{l}6.5 \\
9.2\end{array}$ & $\begin{array}{r}55.6 \\
4.8\end{array}$ & $\begin{array}{r}294.6 \\
3.2\end{array}$ & $\begin{array}{r}728.2 \\
41.7\end{array}$ \\
\hline C & $\begin{array}{l}\text { MEAN } \\
\text { SD }\end{array}$ & $\begin{array}{l}0.1 \\
2.4\end{array}$ & $\begin{array}{l}9.4 \\
4.0\end{array}$ & $\begin{array}{r}18.8 \\
4.2\end{array}$ & $\begin{array}{l}88.9 \\
12.9\end{array}$ & $\begin{array}{r}-0.5 .2 \\
14.5\end{array}$ & $\begin{array}{r}825.2 \\
42.6\end{array}$ \\
\hline D & $\begin{array}{l}\text { MEAN\$ } \\
\text { SD }\end{array}$ & 0.0 & $\begin{array}{r}11.5 \\
7.9\end{array}$ & $\begin{array}{r}18.1 \\
7.5\end{array}$ & $\begin{array}{l}59.0 \\
15.2\end{array}$ & $\begin{array}{r}167.5 \\
18.9\end{array}$ & $\begin{array}{r}477.8 \\
51.9\end{array}$ \\
\hline$E$ & $\begin{array}{l}\text { MEAN } \\
\text { SD }\end{array}$ & $\begin{array}{l}0.7 \\
7.6\end{array}$ & $\begin{array}{r}-0.3 \\
8.8\end{array}$ & $\begin{array}{l}10.5 \\
15.6\end{array}$ & $\begin{array}{l}52.9 \\
48.2\end{array}$ & $\begin{array}{r}120.5 \\
43.5\end{array}$ & $\begin{array}{l}510.4 \\
190.3\end{array}$ \\
\hline $\mathrm{F}$ & $\begin{array}{l}\text { MEAN } \\
\text { SD }\end{array}$ & $\begin{array}{l}2.3 \\
3.1\end{array}$ & $\begin{array}{l}3.8 \\
3.6\end{array}$ & $\begin{array}{l}\text { 8. } 1 \\
3.8\end{array}$ & $\begin{array}{r}34.8 \\
5.1\end{array}$ & $\begin{array}{r}142.1 \\
34.6\end{array}$ & $\begin{array}{l}245.1 \\
155.3\end{array}$ \\
\hline G & $\begin{array}{l}\text { MEAN } \\
\text { SD }\end{array}$ & $\begin{array}{l}2.8 \\
1.5\end{array}$ & $\begin{array}{l}9.9 \\
4.0\end{array}$ & $\begin{array}{r}15.0 \\
3.5\end{array}$ & $\begin{array}{r}52.9 \\
5.9\end{array}$ & $\begin{array}{r}155.8 \\
10.4\end{array}$ & $\begin{array}{l}415.5 \\
107.6\end{array}$ \\
\hline$H$ & $\begin{array}{l}\text { MEAN } \\
\text { SD }\end{array}$ & $\begin{array}{l}\text { S. } 1 \\
\text { a. } 7\end{array}$ & $\begin{array}{r}24.0 \\
8.4\end{array}$ & $\begin{array}{l}34.4 \\
12.3\end{array}$ & $\begin{array}{l}94.5 \\
14.6\end{array}$ & $\begin{array}{r}309.5 \\
3.9\end{array}$ & $\begin{array}{r}805.8 \\
51.8\end{array}$ \\
\hline I & $\begin{array}{c}\text { MEAN } \\
\text { SD }\end{array}$ & -- & -- & -- & -- & -- & - \\
\hline $\mathrm{J}$ & $\begin{array}{c}\text { MEAN } \\
S D\end{array}$ & -- & -- & - & -- & -- & - \\
\hline$k$ & $\begin{array}{l}\text { MEAN } \\
\text { SD }\end{array}$ & $\begin{array}{l}4.1 \\
5.1\end{array}$ & $\begin{array}{r}15.5 \\
2.6\end{array}$ & $\begin{array}{r}24.4 \\
3.0\end{array}$ & $\begin{array}{r}98.7 \\
4.6\end{array}$ & $\begin{array}{r}294.3 \\
20.2\end{array}$ & $\begin{array}{r}787.6 \\
28.0\end{array}$ \\
\hline L & $\begin{array}{c}\text { MEAN } \\
S D\end{array}$ & $\begin{array}{r}0.2 \\
28.2\end{array}$ & $\begin{array}{r}-10.1 \\
29.4\end{array}$ & $\begin{array}{r}2.2 \\
18.2\end{array}$ & $\begin{array}{l}16.3 \\
38.6\end{array}$ & $\begin{array}{r}210.1 \\
17.2\end{array}$ & $\begin{array}{r}535.6 \\
58.9\end{array}$ \\
\hline TOTAL & MEAN & 1.8 & 7.9 & 16.8 & 62.9 & 233.9 & s2s. 1 \\
\hline
\end{tabular}


TABLE A.3. Mean and Standard Deviation Summary of March Data, Phase 1. No 80 mrem irradiations were measured this month.

\begin{tabular}{|c|c|c|c|c|c|c|c|}
\hline \multicolumn{2}{|c|}{ Contractor } & CONTFOL & $10 \mathrm{MF}$ & $20 \mathrm{MF}$ & $80 \mathrm{MF}$ & $300 \mathrm{MF}$ & $800 \mathrm{MF}$ \\
\hline$A$ & $\begin{array}{l}\text { MEAN } \\
\text { SD }\end{array}$ & 0.0 & $\begin{array}{r}12.4 \\
6.8\end{array}$ & $\begin{array}{l}15.0 \\
15.4\end{array}$ & -- & $\begin{array}{r}517.0 \\
55.7\end{array}$ & $\begin{array}{r}727.5 \\
65.4\end{array}$ \\
\hline$E$ & $\begin{array}{l}\text { MEAN } \\
\text { SD }\end{array}$ & $\begin{array}{r}-1.2 \\
1.9\end{array}$ & $\begin{array}{l}0.0 \\
0.0\end{array}$ & $\begin{array}{r}10.7 \\
7.2\end{array}$ & -- & $\begin{array}{r}274.6 \\
29.0\end{array}$ & $\begin{array}{r}7.5 .1 \\
6.5 .5\end{array}$ \\
\hline c & $\begin{array}{l}\text { MEAN } \\
\text { SD }\end{array}$ & $\begin{array}{r}-0.4 \\
1.5\end{array}$ & $\begin{array}{l}7.9 \\
3.4\end{array}$ & $\begin{array}{l}24.0 \\
20.5\end{array}$ & -- & $\begin{array}{r}285.6 \\
51.6\end{array}$ & $\begin{array}{r}799.4 \\
32.2\end{array}$ \\
\hline D & $\begin{array}{c}\text { MEAN } \\
\text { SD }\end{array}$ & 0.0 & $\begin{array}{l}4.6 \\
4.7\end{array}$ & $\begin{array}{l}15.2 \\
12.6\end{array}$ & -- & $\begin{array}{r}143.3 \\
16.8\end{array}$ & $\begin{array}{r}406.8 \\
26.4\end{array}$ \\
\hline$E$ & $\begin{array}{l}\text { MEAN } \\
\text { SD }\end{array}$ & $\begin{array}{r}-4.7 \\
4.1\end{array}$ & $\begin{array}{r}0.1 \\
12.9\end{array}$ & $\begin{array}{l}10.9 \\
19.9\end{array}$ & -- & $\begin{array}{r}111.0 \\
41.0\end{array}$ & $\begin{array}{r}291.0 \\
70.8\end{array}$ \\
\hline$F$ & $\begin{array}{c}\text { MEAN } \\
\text { SD }\end{array}$ & 1.1 & $\begin{array}{l}5.2 \\
6.7\end{array}$ & $\begin{array}{l}5.1 \\
5.0\end{array}$ & -- & $\begin{array}{l}90.4 \\
12.2\end{array}$ & $\begin{array}{r}292.4 \\
47.3\end{array}$ \\
\hline G & $\begin{array}{c}\text { MEAN } \\
\text { SD }\end{array}$ & $\begin{array}{l}6.5 \\
1.5\end{array}$ & $\begin{array}{l}9.8 \\
5.5\end{array}$ & $\begin{array}{r}18.4 \\
5.6\end{array}$ & -- & $\begin{array}{r}165.4 \\
28.4\end{array}$ & $\begin{array}{r}447.7 \\
57.8\end{array}$ \\
\hline$H$ & $\begin{array}{c}\text { MEAN } \\
\text { SD }\end{array}$ & $\begin{array}{r}-4.1 \\
4.9\end{array}$ & $\begin{array}{r}14.0 \\
6.7\end{array}$ & $\begin{array}{l}30.7 \\
12.5\end{array}$ & -- & $\begin{array}{r}257.6 \\
50.7\end{array}$ & $\begin{array}{c}767.5 \\
91.1\end{array}$ \\
\hline I & $\begin{array}{l}\text { MEAN } \\
\text { SD }\end{array}$ & $\begin{array}{r}12.8 \\
7.1\end{array}$ & $\begin{array}{l}3.1 \\
17.0\end{array}$ & $\begin{array}{l}46.4 \\
15.2\end{array}$ & -- & $\begin{array}{r}401.0 \\
58.0\end{array}$ & $\begin{array}{r}774.4 \\
55.0\end{array}$ \\
\hline$J$ & $\begin{array}{l}\text { MEAN } \\
\text { SD }\end{array}$ & $\begin{array}{l}0.8 \\
2.0\end{array}$ & $\begin{array}{l}4.0 \\
3.5\end{array}$ & $\begin{array}{l}7.2 \\
1.8\end{array}$ & -- & $\begin{array}{l}96.3 \\
12.2\end{array}$ & $\begin{array}{r}262.9 \\
23.2\end{array}$ \\
\hline$k$ & $\begin{array}{l}\text { MEAN } \\
\text { SD }\end{array}$ & $\begin{array}{r}-11.4 \\
6.0\end{array}$ & $\begin{array}{r}17.1 \\
5.5\end{array}$ & $\begin{array}{r}29.6 \\
6.6\end{array}$ & -- & $\begin{array}{r}313.4 \\
28.5\end{array}$ & $\begin{array}{r}802.1 \\
87.0\end{array}$ \\
\hline$L$ & $\begin{array}{l}\text { MEAN } \\
\text { SD }\end{array}$ & $\begin{array}{l}-0.8 \\
4.5 .4\end{array}$ & $\begin{array}{l}-5.1 \\
30.7\end{array}$ & $\begin{array}{l}37.0 \\
28.1\end{array}$ & -- & $\begin{array}{l}28.5 .2 \\
113.5\end{array}$ & $\begin{array}{c}878.0 \\
33.1\end{array}$ \\
\hline TOTAL & MEAN & -0.1 & 8.6 & 21.0 & -- & 228.3 & 514.7 \\
\hline
\end{tabular}


TABLE A.4. Mean and Standard Deviation Summary of April Data, Phase 1. Contractor I again experienced dosimeter fading.

\begin{tabular}{|c|c|c|c|c|c|c|c|}
\hline \multicolumn{2}{|c|}{ Contractor } & CONTFEL & $10 \mathrm{MF}$ & $20 \mathrm{MFi}$ & $80 \mathrm{MF}$ & $500 \mathrm{MF}$ & $800 \mathrm{MF}$ \\
\hline$A$ & $\begin{array}{l}\text { MEAN } \\
\text { SD }\end{array}$ & 0.0 & $\begin{array}{l}24.7 \\
15.5\end{array}$ & $\begin{array}{l}44.2 \\
12.9\end{array}$ & $\begin{array}{r}109.4 \\
22.9\end{array}$ & $\begin{array}{r}310.4 \\
17.1\end{array}$ & $\begin{array}{r}841.9 \\
77.4\end{array}$ \\
\hline E & $\begin{array}{l}\text { MEAN } \\
\text { SD }\end{array}$ & $\begin{array}{l}0.0 \\
--\end{array}$ & $\begin{array}{r}9.5 \\
16.5\end{array}$ & 0.0 & $\begin{array}{l}75.5 \\
15.5\end{array}$ & $\begin{array}{r}259.5 \\
18.9\end{array}$ & $\begin{array}{r}727.9 \\
60.4\end{array}$ \\
\hline C & $\begin{array}{l}\text { MEAN } \\
\text { SD }\end{array}$ & $\begin{array}{l}0.2 \\
0.4\end{array}$ & $\begin{array}{r}17.9 \\
2.5\end{array}$ & $\begin{array}{r}31.6 \\
4.6\end{array}$ & $\begin{array}{l}98.9 \\
10.0\end{array}$ & $\begin{array}{r}-17.4 \\
\quad 4.5\end{array}$ & $\begin{array}{r}929.5 \\
24.1\end{array}$ \\
\hline$D$ & $\begin{array}{l}\text { MEAN } \\
\text { SD }\end{array}$ & 0.0 & $\begin{array}{l}29.1 \\
12.9\end{array}$ & $\begin{array}{l}42.0 \\
21.8\end{array}$ & $\begin{array}{l}60.5 \\
17.5\end{array}$ & $\begin{array}{r}156.0 \\
24.9\end{array}$ & $\begin{array}{r}430.4 \\
76.1\end{array}$ \\
\hline$E$ & $\begin{array}{l}\text { MEAN } \\
\text { SD }\end{array}$ & $\begin{array}{l}1.5 .2 \\
15.9\end{array}$ & $\begin{array}{l}42.5 \\
13.0\end{array}$ & $\begin{array}{l}50.7 \\
28.6\end{array}$ & $\begin{array}{l}58.3 \\
24.0\end{array}$ & $\begin{array}{r}146.5 \\
71.7\end{array}$ & $\begin{array}{l}471.6 \\
137.4\end{array}$ \\
\hline$F$ & $\begin{array}{l}\text { MEAN } \\
\text { SD }\end{array}$ & 0.0 & $\begin{array}{l}3.6 \\
2.2\end{array}$ & $\begin{array}{l}8.2 \\
3.4\end{array}$ & $\begin{array}{r}27.9 \\
5.4\end{array}$ & $\begin{array}{r}97.6 \\
6.0\end{array}$ & $\begin{array}{r}304.6 \\
11.8\end{array}$ \\
\hline$G$ & $\begin{array}{l}\text { MEAN } \\
\text { SD }\end{array}$ & $\begin{array}{l}2.6 \\
2.1\end{array}$ & $\begin{array}{r}10.2 \\
1.9\end{array}$ & $\begin{array}{r}12.4 \\
3.7\end{array}$ & $\begin{array}{r}41.4 \\
5.9\end{array}$ & $\begin{array}{r}130.0 \\
11.0\end{array}$ & $\begin{array}{r}357.2 \\
40.3\end{array}$ \\
\hline$H$ & $\begin{array}{l}\text { MEAN } \\
\text { SD }\end{array}$ & $\begin{array}{l}2.5 \\
8.5\end{array}$ & $\begin{array}{r}4.9 \\
10.9\end{array}$ & $\begin{array}{r}12.7 \\
6.5\end{array}$ & $\begin{array}{l}64.4 \\
11.7\end{array}$ & $\begin{array}{r}206.4 \\
20.7\end{array}$ & $\begin{array}{r}519.7 \\
27.0\end{array}$ \\
\hline I & $\begin{array}{l}\text { MEAN } \\
\text { SD }\end{array}$ & -- & -- & -- & -- & -- & -- \\
\hline. & $\begin{array}{l}\text { MEAN } \\
\text { SD }\end{array}$ & $\begin{array}{l}0.1 \\
1.5\end{array}$ & $\begin{array}{l}2.4 \\
1.7\end{array}$ & $\begin{array}{l}9.3 \\
4.3\end{array}$ & $\begin{array}{r}26.6 \\
6.7\end{array}$ & $\begin{array}{l}95.6 \\
16.8\end{array}$ & $\begin{array}{r}279.7 \\
28.8\end{array}$ \\
\hline$k$ & $\begin{array}{l}\text { MEAN } \\
\text { SD }\end{array}$ & $\begin{array}{l}3.4 \\
7.0\end{array}$ & $\begin{array}{r}13.0 \\
2.8\end{array}$ & $\begin{array}{r}30.4 \\
6.1\end{array}$ & $\begin{array}{l}79.6 \\
10.2\end{array}$ & $\begin{array}{r}252.6 \\
18.7\end{array}$ & $\begin{array}{r}716.4 \\
88.3\end{array}$ \\
\hline L & $\begin{array}{l}\text { MEAN } \\
\text { SD }\end{array}$ & $\begin{array}{r}0.0 \\
11.4\end{array}$ & $\begin{array}{l}-6.0 \\
18.1\end{array}$ & $\begin{array}{r}0.2 \\
44.9\end{array}$ & $\begin{array}{l}35.5 \\
34.3\end{array}$ & $\begin{array}{r}224.2 \\
28.3\end{array}$ & $\begin{array}{r}55.2 \\
70.2\end{array}$ \\
\hline TOTAL & MEAN & 2.0 & 14.2 & 22.0 & 60.5 & 200.6 & 557.5 \\
\hline
\end{tabular}


TABLE A.5. Accuracy of Phase 1 Neutron Dosimeter Response as Measured by the Relative Bias. Accuracy is reported by contractor and irradiation level with averages computed for each contractor. Random is a set of 15 dosimeters exposed to randomly selected doses of unmoderated Californium between 50 and $800 \mathrm{rem}$. The average total accuracy for all contractors is an underresponse of $17 \%$. The range of neutron dosimeter accuracies by contractor is from $-66 \%$ to $+83 \%$.

\begin{tabular}{|c|c|c|c|c|c|c|c|}
\hline Contractor & $10 \mathrm{MR}$ & $20 \mathrm{MR}$ & 80 MF & $500 \mathrm{MR}$ & $800 \mathrm{MR}$ & FANDOM & AVEFAGE \\
\hline A & .75 & b. & .28 & .05 & .08 & -.00 & .26 \\
\hline B & -.71 & -.56 & -.15 & -.09 & -.09 & -.20 &.- .54 \\
\hline C & .14 & .17 & .11 & .02 & .02 & -.04 & .05 \\
\hline D & .56 & .08 & -.25 & -.48 & -.46 & -.47 & -.18 \\
\hline$E$ & .27 & -.08 & -.29 & -.59 & -.47 & -.60 & -.27 \\
\hline$F$ & -.58 &.- .54 & -.52 & -.65 & -.55 & -.68 & -.6 .5 \\
\hline G & .00 & -.21 & -.44 & -.48 & -.50 & -.55 &.- .34 \\
\hline$H$ & .48 & .45 & -.07 & -.14 & -.13 & -.26 & .09 \\
\hline I & 2.31 & 1.32 & -- & .34 & .05 & -.26 & .93 \\
\hline J & -.67 & -.60 & -.67 & -.68 & -.66 & os & -.56 \\
\hline$k$ & .58 & .38 & .05 & .02 & -.04 & -- & .24 \\
\hline L & -1.71 & -.22 & -.65 & -.17 & -.10 & -.27 & -.54 \\
\hline TOTAL & .01 & -.02 & -.22 & -.26 & -.24 & -.56 & -.17 \\
\hline
\end{tabular}


TABLE A.6. Precision of Phase 1 Neutron Dosimeter Response as Measured by the Coefficient of Variation. Precision is reported by irradiation level and contractor and averages given for each contractor across all irradiations. Note the large precision values at the lower irradiation levels indicating the difficulty in assessing response. The total average precision for all Phase 1 dosimeters is 0.79 or the standard deviation averages $70 \%$ of the reported response.

\begin{tabular}{|c|c|c|c|c|c|c|}
\hline Contractor & $10 \mathrm{MF}$ & $20 \mathrm{MR}$ & $80 \mathrm{MR}$ & $300 \mathrm{MF}$ & $800 \mathrm{MF}$ & AVEFAGE \\
\hline A & .81 & .75 & .22 & .12 & .09 & .43 \\
\hline$E$ & 5.54 & 1.20 & .24 & .10 & .07 & 1.08 \\
\hline C & .48 & .58 & .12 & .15 & .04 & .50 \\
\hline D & .95 & .75 & .27 & .14 & .14 & .48 \\
\hline$\varepsilon$ & 1.80 & 1.54 & .54 & .41 & 30 & .94 \\
\hline$F$ & 1.10 & .47 & .21 & .27 & .31 & .50 \\
\hline G & .32 & .31 & .18 & .17 & .20 & .24 \\
\hline$H$ & .77 & .48 & .26 & .21 & .21 & .40 \\
\hline$I$ & .51 & .32 & - & .15 & .07 & .26 \\
\hline J & .87 & .37 & .25 & .14 & .10 & .5 \\
\hline$k$ & .18 & .21 & .12 & .11 & .10 & .15 \\
\hline L & $\therefore .62$ & 2.08 & 1.25 & .35 & .18 & 1.58 \\
\hline TOTAL & 1.52 & .94 & .49 & .44 & .37 & .79 \\
\hline
\end{tabular}


TABLE A.7. Means and Standard Deviations (SD) of Phase 2 Neutron Dosimeter Response Reported by Contractor and Irradiation Level. Each contractor was provided calibrations information and asked to reanalyze their Phase 1 data. Contractors $I, J$, and $K$ did not provide reanalyzed data. Note the significant improvement in the higher irradiation levels.

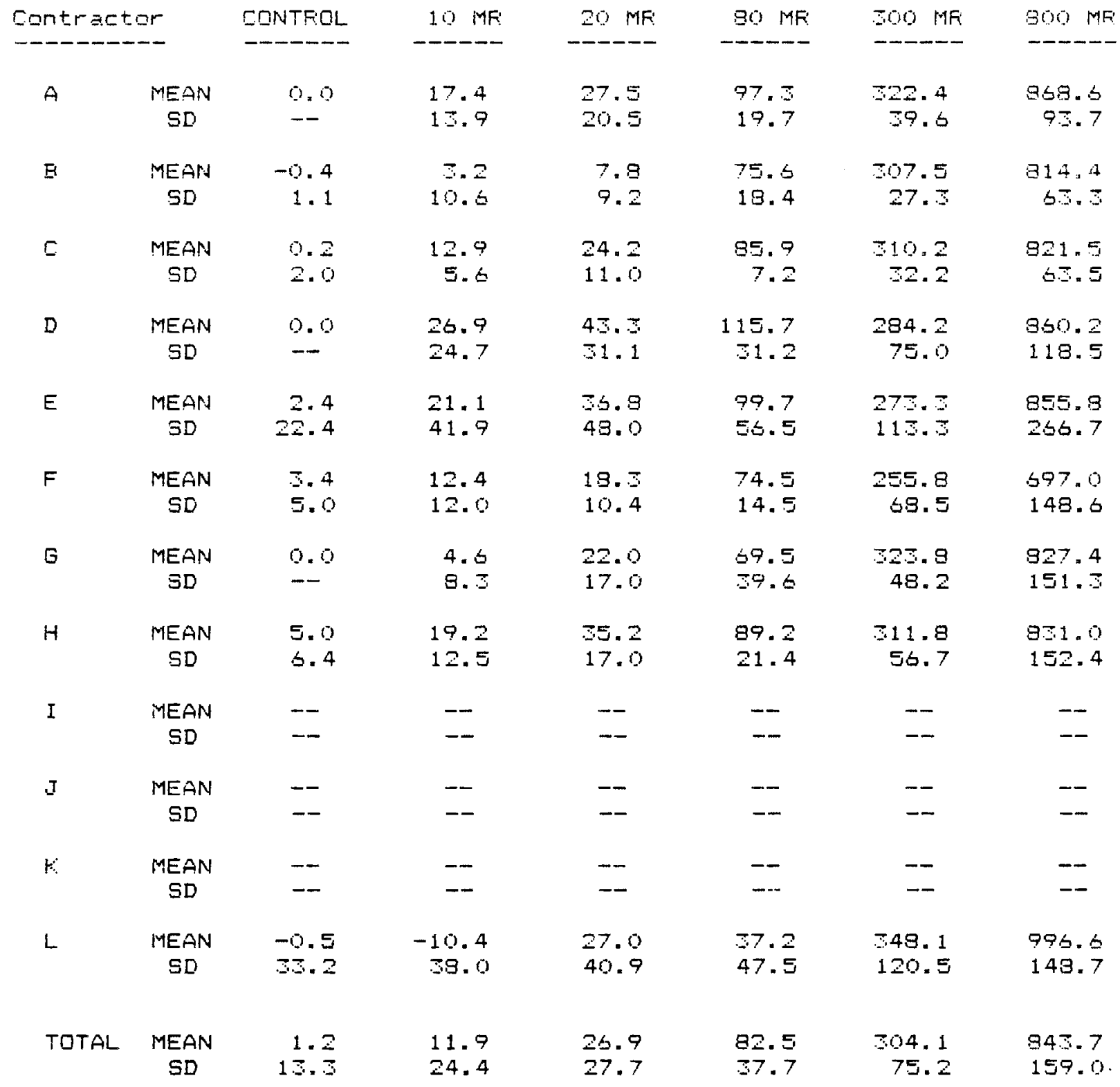


TABLE A.8. Mean and Standard Deviation Summary of February Data, Phase 2. Phase 1 data was reanalyzed using appropriate calibration information.

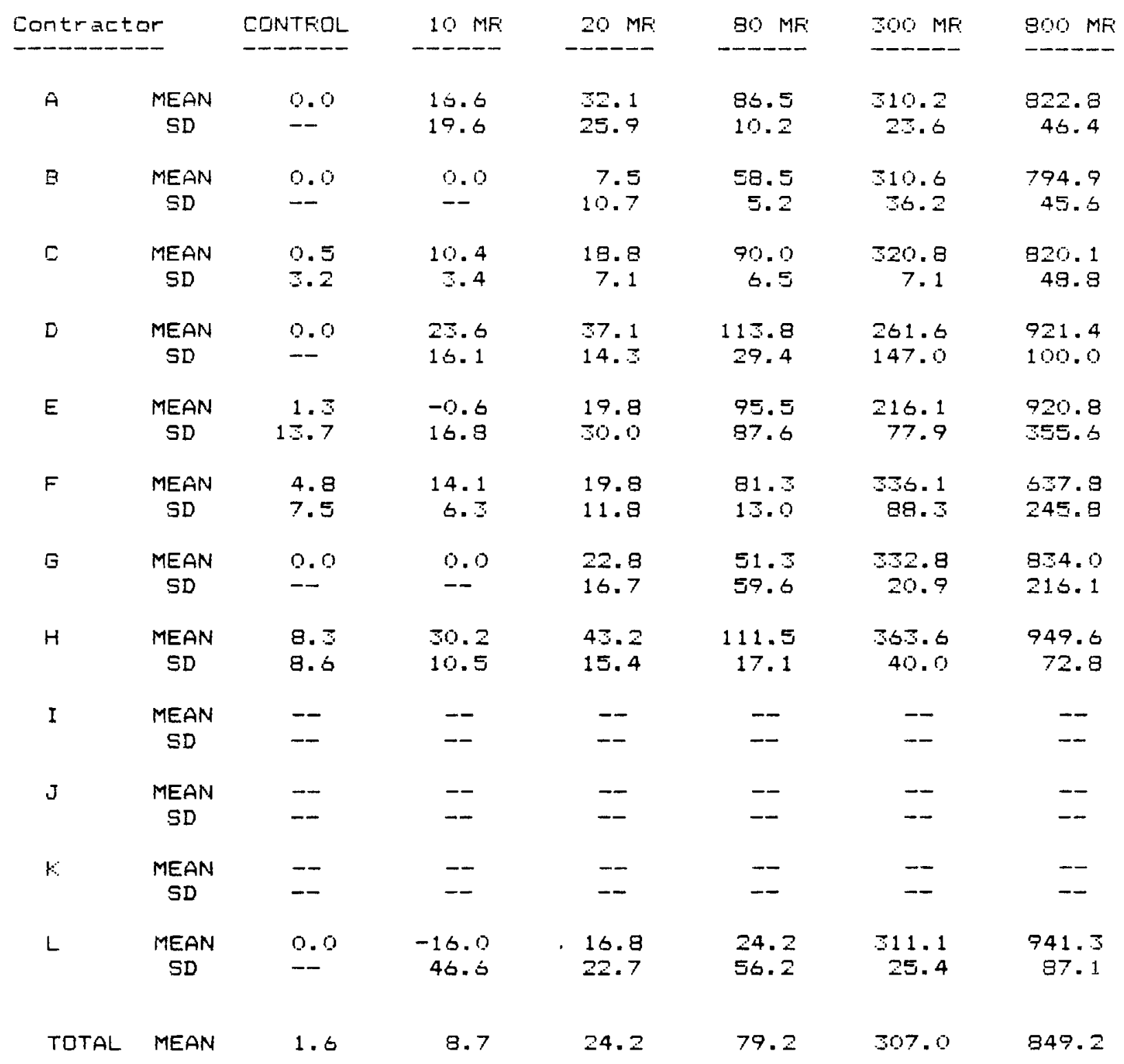


TABLE A.9. Means and Standard Deviations of March Data, Phase 2. There were no 80 mrem irradiations this month.

\begin{tabular}{|c|c|c|c|c|c|c|c|}
\hline \multicolumn{2}{|c|}{ Contractor } & CONTFOL & $10 \mathrm{MF}$ & $20 \mathrm{Mr}$ & $80 \mathrm{MF}$ & $300 \mathrm{MF}$ & $800 \mathrm{MF}$ \\
\hline A & $\begin{array}{l}\text { MEAN } \\
\text { SD }\end{array}$ & 0.0 & $\begin{array}{r}15.8 \\
7.6\end{array}$ & $\begin{array}{l}17.1 \\
14.5\end{array}$ & $\begin{array}{l}-- \\
--\end{array}$ & $\begin{array}{r}59.1 \\
47.8\end{array}$ & $\begin{array}{r}967.5 \\
68.0\end{array}$ \\
\hline $\mathrm{B}$ & $\begin{array}{l}\text { MEAN } \\
\text { SD }\end{array}$ & $\begin{array}{r}-1.2 \\
1.8\end{array}$ & $\begin{array}{l}0.0 \\
0.0\end{array}$ & $\begin{array}{r}12.0 \\
7.9\end{array}$ & -- & $\begin{array}{r}508.8 \\
27.8\end{array}$ & $\begin{array}{r}802.5 \\
71.5\end{array}$ \\
\hline C & $\begin{array}{l}\text { MEAN } \\
S D\end{array}$ & $\begin{array}{r}-0.2 \\
1.3\end{array}$ & $\begin{array}{l}9.6 \\
2.4\end{array}$ & $\begin{array}{l}27.1 \\
14.7\end{array}$ & -- & $\begin{array}{r}302.3 \\
38.9\end{array}$ & $\begin{array}{r}822.1 \\
8 \Xi .1\end{array}$ \\
\hline D & $\begin{array}{l}\text { MEAN } \\
\text { SD }\end{array}$ & $\begin{array}{l}0.0 \\
--\end{array}$ & $\begin{array}{l}9.4 \\
9.9\end{array}$ & $\begin{array}{l}30.5 \\
24.4\end{array}$ & -- & $\begin{array}{r}295.7 \\
85.5\end{array}$ & $\begin{array}{r}784.9 \\
50.9\end{array}$ \\
\hline E & $\begin{array}{l}\text { MEAN } \\
\text { SD }\end{array}$ & $\begin{array}{r}-12.5 \\
11.3\end{array}$ & $\begin{array}{r}0.5 \\
36.6\end{array}$ & $\begin{array}{l}31.2 \\
51.5\end{array}$ & -- & $\begin{array}{l}302.5 \\
115.8\end{array}$ & $\begin{array}{l}7.55 .4 \\
195.6\end{array}$ \\
\hline$F$ & $\begin{array}{l}\text { MEAN } \\
\text { SD }\end{array}$ & $\begin{array}{l}3.7 \\
3.4\end{array}$ & $\begin{array}{l}13.9 \\
19.2\end{array}$ & $\begin{array}{l}14.3 \\
10.0\end{array}$ & -- & $\begin{array}{r}221.9 \\
35.8\end{array}$ & $\begin{array}{l}576.5 \\
117.2\end{array}$ \\
\hline G & $\begin{array}{l}\text { MEAN } \\
S D\end{array}$ & $\begin{array}{l}0.0 \\
--\end{array}$ & $\begin{array}{l}2.2 \\
5.7\end{array}$ & $\begin{array}{l}19.7 \\
21.6\end{array}$ & - & $\begin{array}{r}542.4 \\
53.5\end{array}$ & $\begin{array}{l}898.7 \\
115.9\end{array}$ \\
\hline$H$ & $\begin{array}{l}\text { MEAN } \\
\text { SD }\end{array}$ & $\begin{array}{l}0.8 \\
1.8\end{array}$ & $\begin{array}{r}17.5 \\
3.5\end{array}$ & $\begin{array}{l}37.3 \\
14.5\end{array}$ & -- & $\begin{array}{r}512.3 \\
52.2\end{array}$ & $\begin{array}{r}904.5 \\
95.5\end{array}$ \\
\hline I & $\begin{array}{l}\text { MEAN } \\
\text { SD }\end{array}$ & -- & $\begin{array}{l}-- \\
--\end{array}$ & -- & -- & -- & -- \\
\hline $\mathrm{J}$ & $\begin{array}{c}\text { MEAN } \\
\text { SD }\end{array}$ & $\begin{array}{l}-- \\
--\end{array}$ & -- & -- & -- & -- & -- \\
\hline 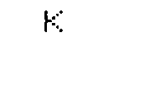 & $\begin{array}{l}\text { MEAN } \\
\text { SD }\end{array}$ & -- & -- & -- & -- & -- & -- \\
\hline$L$ & $\begin{array}{l}\text { MEAN } \\
\text { SD }\end{array}$ & $\begin{array}{l}-1.2 \\
60.5\end{array}$ & $\begin{array}{l}-7.3 \\
4.5 .5\end{array}$ & $\begin{array}{l}50.8 \\
38.5\end{array}$ & $\begin{array}{l}-- \\
--\end{array}$ & $\begin{array}{l}389.8 \\
160.6\end{array}$ & $\begin{array}{r}1170.2 \\
44.0\end{array}$ \\
\hline TOTAL & MEAN & -1.2 & 6.6 & 26.7 & -- & 511.4 & 965.6 \\
\hline
\end{tabular}


TABLE A.10. Mean and Standard Deviation Summary of April Data, Phase 2.

\begin{tabular}{|c|c|c|c|c|c|c|c|}
\hline \multicolumn{2}{|c|}{ Contractor } & CONTFOL & $10 \mathrm{MR}$ & $20 \mathrm{MF}$ & $80 \mathrm{MF}:$ & $500 \mathrm{MF}$ & $800 \mathrm{MF}$ \\
\hline A & $\begin{array}{l}\text { MEAN } \\
\text { SD }\end{array}$ & 0.0 & $\begin{array}{l}22.5 \\
12.5\end{array}$ & $\begin{array}{l}40.2 \\
11.7\end{array}$ & $\begin{array}{r}102.7 \\
21.4\end{array}$ & $\begin{array}{r}501.0 \\
16.5\end{array}$ & $\begin{array}{r}815.6 \\
74.8\end{array}$ \\
\hline E & $\begin{array}{l}\text { MEAN } \\
\text { SD }\end{array}$ & 0.0 & $\begin{array}{l}10.2 \\
17.8\end{array}$ & 0.0 & $\begin{array}{l}85.2 \\
15.9\end{array}$ & $\begin{array}{r}301.7 \\
22.0\end{array}$ & $\begin{array}{r}84.5 .1 \\
70.2\end{array}$ \\
\hline C & $\begin{array}{l}\text { MEAN } \\
\text { SD }\end{array}$ & $\begin{array}{l}0.4 \\
1.5\end{array}$ & $\begin{array}{r}19.7 \\
4.4\end{array}$ & $\begin{array}{r}29.6 \\
2.9\end{array}$ & $\begin{array}{r}8.8 .8 \\
7.0\end{array}$ & $\begin{array}{r}515.6 \\
5.9\end{array}$ & $\begin{array}{r}822.4 \\
69.6\end{array}$ \\
\hline D. & $\begin{array}{l}\text { MEAN } \\
\text { SD }\end{array}$ & 0.0 & $\begin{array}{l}55.9 \\
24.5\end{array}$ & $\begin{array}{l}81.5 \\
42.5\end{array}$ & $\begin{array}{r}115.5 \\
5.4\end{array}$ & $\begin{array}{r}507.6 \\
30.6\end{array}$ & $\begin{array}{l}886.6 \\
154.3\end{array}$ \\
\hline$E$ & $\begin{array}{l}\text { MEAN } \\
\text { SD }\end{array}$ & $\begin{array}{l}18.4 \\
29.1\end{array}$ & $\begin{array}{l}70.5 \\
23.9\end{array}$ & $\begin{array}{l}81.3 \\
52.3\end{array}$ & $\begin{array}{r}101.4 \\
45.2\end{array}$ & $\begin{array}{l}272.0 \\
136.2\end{array}$ & $\begin{array}{l}98.4 .4 \\
231.0\end{array}$ \\
\hline $\mathrm{F}$ & $\begin{array}{l}\text { MEAN } \\
\text { SD }\end{array}$ & $\begin{array}{l}1.5 \\
2.2\end{array}$ & $\begin{array}{l}7.8 \\
7.5\end{array}$ & $\begin{array}{r}23.4 \\
3.8\end{array}$ & $\begin{array}{l}71.1 \\
14.7\end{array}$ & $\begin{array}{r}24.4 .4 \\
19.4\end{array}$ & $\begin{array}{r}760.8 \\
40.4\end{array}$ \\
\hline 6 & $\begin{array}{l}\text { MEAN } \\
\text { SD }\end{array}$ & 0.0 & $\begin{array}{l}12.8 \\
10.2\end{array}$ & $\begin{array}{r}25.0 \\
7.4\end{array}$ & $\begin{array}{l}76.8 \\
29.6\end{array}$ & $\begin{array}{r}277.8 \\
23.4\end{array}$ & $\begin{array}{r}76.3 .7 \\
86.1\end{array}$ \\
\hline$H$ & $\begin{array}{c}\text { MEAN } \\
\text { SD }\end{array}$ & $\begin{array}{l}5.9 \\
5.4\end{array}$ & $\begin{array}{l}3.5 \\
8.2\end{array}$ & $\begin{array}{r}15.0 \\
7.7\end{array}$ & $\begin{array}{l}79.1 \\
13.1\end{array}$ & $\begin{array}{r}259.0 \\
26.0\end{array}$ & $\begin{array}{r}65.5 \\
31.9\end{array}$ \\
\hline I & $\begin{array}{l}\text { MEAN } \\
\text { SD }\end{array}$ & $\begin{array}{l}-- \\
--\end{array}$ & $\begin{array}{l}-- \\
--\end{array}$ & $\begin{array}{l}-- \\
--\end{array}$ & -- & - & -- \\
\hline$J$ & $\begin{array}{c}\text { MEAN } \\
\text { SD }\end{array}$ & -- & -- & -- & -- & - & $\begin{array}{l}-- \\
--\end{array}$ \\
\hline$k$ & $\begin{array}{l}\text { MEAN } \\
\text { SD }\end{array}$ & -- & - & $\overline{--}$ & -- & $\overline{--}$ & -- \\
\hline L & $\begin{array}{c}\text { MEAN } \\
\text { SD }\end{array}$ & $\begin{array}{l}-0.2 \\
14.3\end{array}$ & $\begin{array}{l}-7.7 \\
23.1\end{array}$ & $\begin{array}{r}0.3 \\
56.0\end{array}$ & $\begin{array}{l}43.7 \\
44.4\end{array}$ & $\begin{array}{r}501.6 \\
58.3\end{array}$ & $\begin{array}{r}878.4 \\
94.5\end{array}$ \\
\hline TOTAL & MEAN & -3.2 & 22.2 & 3.0 & 84.4 & 286.6 & 812.3 \\
\hline
\end{tabular}


TABLE A.11. Accuracy of Phase 2 Neutron Dosimeter Response as Measured by the Relative Bias. Note the improvement over Phase 1 accuracy when the data is reanalyzed given appropriate calibrations. The average total accuracy for all Phase 2 dosimeters now shows an $11 \%$ over-response. Most of this is accounted for by the 10 and $20 \mathrm{mrem}$ irradiations.

\begin{tabular}{|c|c|c|c|c|c|c|c|}
\hline Contractor & $10 \mathrm{MF}$ & $20 \mathrm{MF}$ & $30 \mathrm{MF}$ & $300 \mathrm{MF}$ & $800 \mathrm{MR}$ & RANDOM & AUEFIAGE \\
\hline A & .74 & .58 & .22 & .00 & .09 & -.01 & .27 \\
\hline B & -.68 & -.61 & -.00 & .02 & .02 & -.07 & -.26 \\
\hline E & $=29$ & .21 & .07 & .05 & .03 & -.02 & .11 \\
\hline D & 1.59 & 1.16 & .45 & -.05 & .08 & .08 & .62 \\
\hline$E$ & 1.11 & .84 & .25 & -.09 & .07 & -.15 & .38 \\
\hline$F$ & .24 & -.08 & -.07 & -.15 & -.15 & -.23 & -.05 \\
\hline $\mathrm{G}$ & -.54 & .10 & -.15 & .08 & .05 & -.02 & -.09 \\
\hline$H$ & .92 & .76 & .12 & .04 & .04 & -.08 & .34 \\
\hline I & $-\infty$ & - & -- & -- & -- & -- & -- \\
\hline J & -- & -- & $-\infty$ & - & - & - & $-\infty$ \\
\hline$k$ & -- & -- & -- & - & -- & -- & -- \\
\hline$L$ & -2.04 & .35 & -.54 & .16 & .24 & .05 & -.32 \\
\hline TOTAL & .19 & .54 & .05 & .01 & .05 & -.05 & .11 \\
\hline
\end{tabular}


TABLE A.12. Precision of Phase 2 Neutron Dosimeter Response as Measured by the Coefficient of Variation. Note that the values here are very similar to those of Phase 1 . The precision remains essentially the same when recalibration takes place.

\begin{tabular}{|c|c|c|c|c|c|c|}
\hline Contractor & $10 \mathrm{MF}$ & $20 \mathrm{MF}$ & $80 \mathrm{MF}$ & $300 \mathrm{MF}$ & $800 \mathrm{MF}$ & AVEFAGE \\
\hline A & .80 & .74 & .20 & .12 & .11 & .42 \\
\hline$E$ & 3.31 & 1.18 & .24 & .09 & .08 & 1.07 \\
\hline$c$ & .45 & .46 & .08 & .10 & .08 & .25 \\
\hline D & .92 & .72 & .27 & .26 & .14 & .49 \\
\hline$E$ & 1.99 & 1.30 & .56 & .41 & $\Xi 1$ & .95 \\
\hline$F$ & .97 & .56 & .20 & .27 & .21 & .47 \\
\hline 5 & 1.80 & .77 & .57 & .15 & .18 & .75 \\
\hline$H$ & .65 & $.4 E$ & .24 & .18 & .18 & .36 \\
\hline I & -- & -- & -- & -- & - & - \\
\hline J & - & -- & - & -- & -- & -- \\
\hline$k$ & -- & - & -- & -- & -- & -- \\
\hline L & 3.65 & 1.52 & 1.29 & .34 & .15 & 1.46 \\
\hline TOTAL & 1.51 & .86 & .41 & .22 & .16 & .39 \\
\hline
\end{tabular}


TABLE A.13. Regression Analysis of Neutron Dosimeter Response Indicated that the Data Fit a Straight Line with a High Correlation ( $r$ ) in all Cases. The regression analysis was performed on the given irradiation versus the reported response. Note that the Phase 2 data comes very close to a slope of 1.0 which would be expected when the given and reported values are equal.

\begin{tabular}{|c|c|c|c|c|c|c|}
\hline \multirow{2}{*}{ Contractor } & \multicolumn{3}{|c|}{ FHASE 1} & \multicolumn{3}{|c|}{ FHASE 2} \\
\hline & SLOFE & INTEFCEFT & Fi & SLDFE & INTEF:CEFT & $\mathrm{F}$ \\
\hline A & 1.07 & 6.0 & .99 & 1.07 & 5.2 & .99 \\
\hline E & .92 & -7.4 & 1.00 & 1.03 & -7.7 & 1.00 \\
\hline c & 1.01 & 3.3 & 1.00 & 1.02 & 5.6 & 1.00 \\
\hline D & .55 & 9.0 & .78 & 1.04 & 15.5 & .99 \\
\hline$E$ & .51 & 2.2 & .89 & 1.04 & 5.9 & .92 \\
\hline$F$ & .53 & 2.7 & .90 & .86 & 1.8 & .95 \\
\hline G & .50 & 5.7 & .97 & 1.04 & -2.0 & .98 \\
\hline$H$ & .35 & 7.0 & .97 & 1.02 & 9.7 & .97 \\
\hline I & .75 & 31.6 & .94 & -- & -- & -- \\
\hline$J$ & .35 & 2.4 & .99 & -- & -- & -- \\
\hline$k$ & .95 & 7.7 & .99 & -- & -- & -- \\
\hline$L$ & .92 & -20.3 & .97 & 1.27 & -26.2 & .97 \\
\hline
\end{tabular}


TABLE A.14. The Lower Detection Limit (LDL) is determined by the Standard deviations of the background $(0 \mathrm{mrem})$ and of the LDL combined with the level of acceptable error. Tabulated are the LDLs that result from acceptable of $5 \%, 10 \%$, and $20 \%$ ( and are equal). With a $10 \%$ acceptible error the average LDL is $58 \mathrm{mrem}$. If the 2 highest values are neglected (contractors $E$ and $L$ ) the $L D L$ is down to $34 \mathrm{mrem}$. The values for the standard deviations are estimated from control and low irradiation dosimeter data.

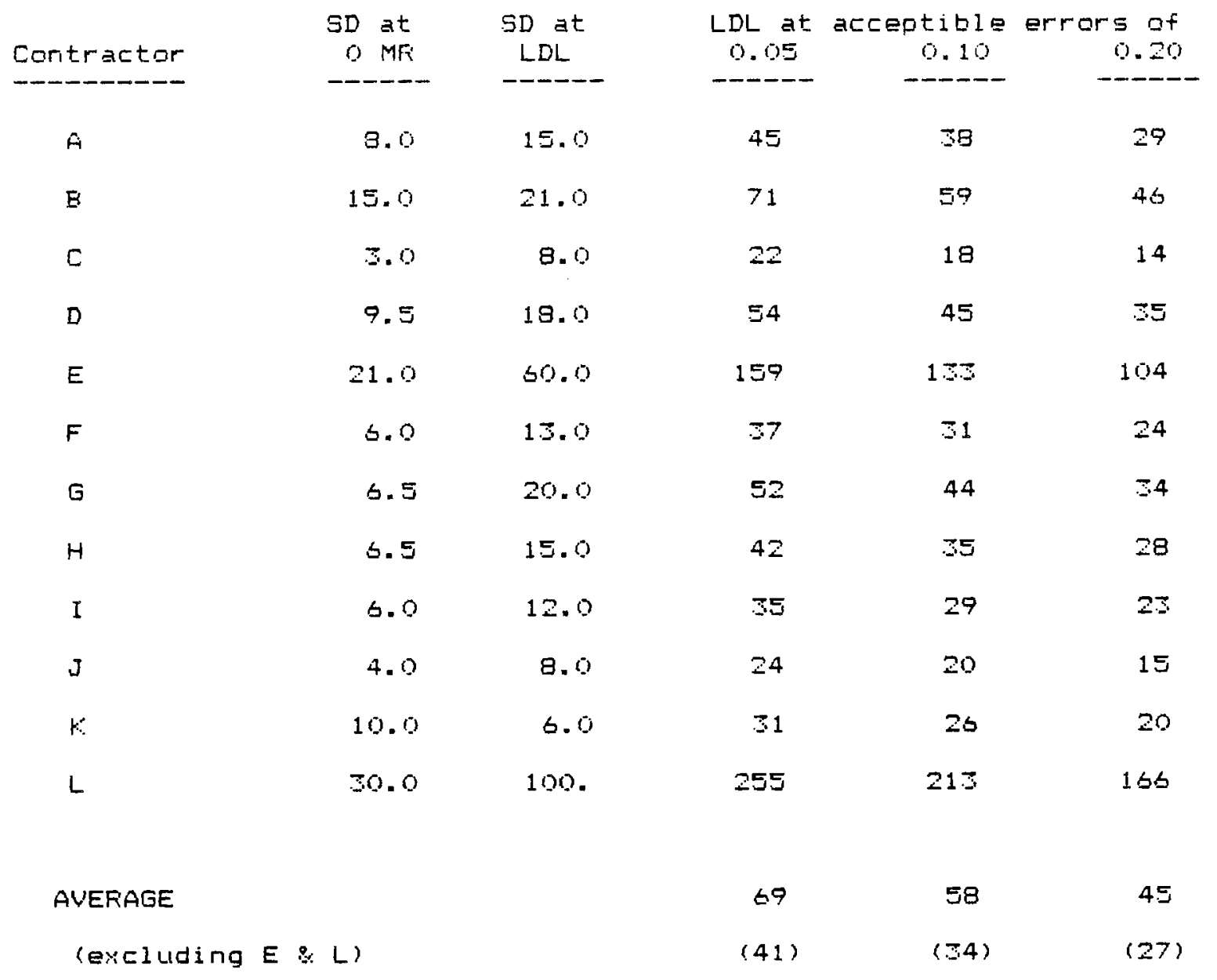


TABLE A.15. Means and Standard Deviations (SD) of Phase 3 Neutron Dosimeter Irradiated with an Unmoderated Californium Source in a High Scatter Facility. Low scatter results are included for comparison.

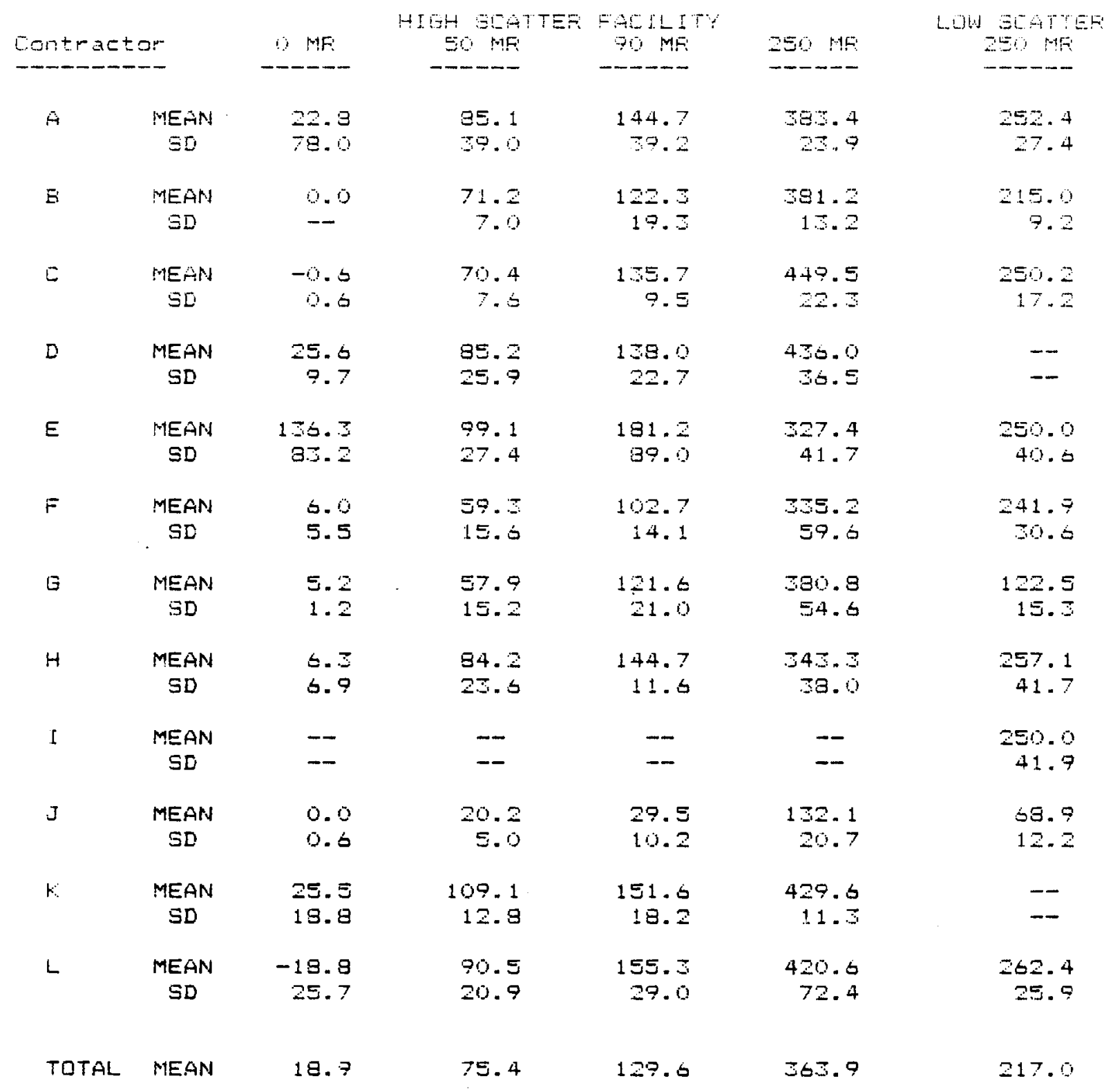


TABLE A.16. Accuracy of Neutron Dosimeter Response to a High Scatter Facility is reported by contractor and irradiation level with averages for each contractor. The average over-response of all dosimeter at the 250 mrem irradiation level is $38 \%$ as compared to the same irradiation in a low scatter environment.

\begin{tabular}{|c|c|c|c|c|}
\hline Contractor & $50 \mathrm{MF}$ & $90 \mathrm{MF}$ & $250 \mathrm{MF}$ & AVEFAGE \\
\hline A & .24 & .55 & .44 & .32 \\
\hline B & .42 & .36 & .52 & .42 \\
\hline C & .42 & .51 & .80 & .55 \\
\hline D & .19 & .25 & .64 & .30 \\
\hline$E$ & -1.74 & -.50 & -.24 & -.94 \\
\hline$F$ & .07 & .07 & .52 & .12 \\
\hline$G$ & .05 & .29 & .50 & .24 \\
\hline$H$ & .56 & .54 & .35 & .51 \\
\hline I & -- & -- & -- & -- \\
\hline J & -.60 & -.67 & -.47 & -.60 \\
\hline$k$ & .67 & .40 & .62 & .55 \\
\hline$L$ & 1.19 & .95 & .75 & 1.00 \\
\hline TOTAL & .15 & .23 & .38 & .22 \\
\hline
\end{tabular}


TABLE A.17. Precision of Neutron Dosimeter Response to the High Scatter Environment as Reported by Contractor and Irradiation Level

\begin{tabular}{|c|c|c|c|c|}
\hline Contractor & $50 \mathrm{MF}$ & $90 \mathrm{MF}$ & $250 \mathrm{MF}$ & AVERAGE \\
\hline A & .65 & .3 & .07 & .59 \\
\hline E & .09 & .16 & .04 & .11 \\
\hline E & .11 & .07 & .05 & .08 \\
\hline$D$ & .44 & .20 & .09 & .27 \\
\hline$E$ & -- & 1.78 & .22 & 1.39 \\
\hline$F$ & .29 & .15 & .18 & .21 \\
\hline$G$ & .29 & .18 & .15 & .22 \\
\hline $\mathrm{H}$ & .30 & .08 & .11 & .17 \\
\hline I & -- & -- & -- & -- \\
\hline J & .25 & .34 & .16 & .27 \\
\hline$r$ & .15 & .14 & .05 & .12 \\
\hline L & .19 & .17 & .16 & .18 \\
\hline TOTAL & .29 & .35 & .11 & .27 \\
\hline
\end{tabular}


TABLE A.18. Means and Standard Deviations of Neutron Dosimeter Response to Moderated Californium. These irradiations are part of the Phase 3 energy response study.

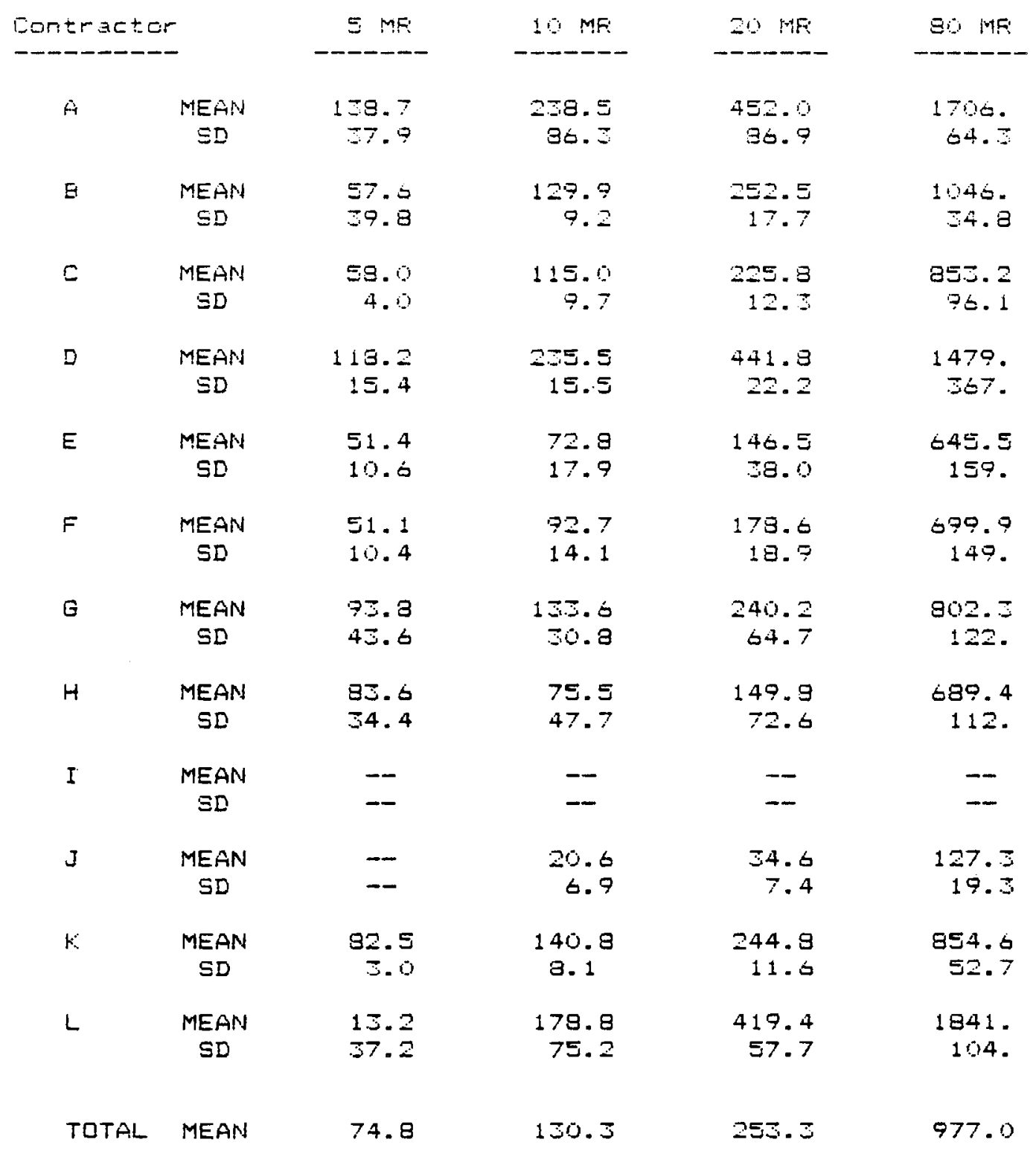


TABLE A.19. Accuracy of Dosimeter Response to Unmoderated Californium as Measured by the Relative Bias. Note that the total accuracy for all contractors is constant across the irradiation levels with an over-response of $1150 \%$.

\begin{tabular}{|c|c|c|c|c|c|}
\hline Contractar & $\Xi M F$ & $10 \mathrm{MF}$ & $20 \mathrm{MF}$ & $80 \mathrm{MR}$ & AVEFIAGE \\
\hline A & 26.7 & 22.8 & 21.6 & 20.3 & 22.6 \\
\hline E & 10.5 & 12.0 & 11.6 & 12.1 & 11.5 \\
\hline C & 10.2 & 10.4 & 10.2 & 9.7 & 10.2 \\
\hline$D$ & 22.6 & 22.6 & 21.1 & 17.5 & 21.2 \\
\hline$E$ & 5.5 & 5.3 & 5.8 & 7.1 & 5.8 \\
\hline$F$ & 8.6 & 8.0 & 7.8 & 7.7 & 8.0 \\
\hline G & 17.8 & 12.4 & 11.0 & 9.0 & 12.3 \\
\hline$H$ & 7.5 & 2.4 & 4.4 & 7.1 & 4.7 \\
\hline I & -- & - & -- & -- & - \\
\hline$J$ & -- & 0.8 & 0.6 & 0.6 & 0.7 \\
\hline 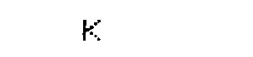 & 0.7 & 7.9 & 8.5 & 9.5 & 7.2 \\
\hline$L$ & 4.9 & 18.9 & 21.0 & 22.3 & 17.8 \\
\hline TOTAL & 11.5 & 11.2 & 11.2 & 11.2 & 11.2 \\
\hline
\end{tabular}


TABLE A.20. Means and Standard Deviations of Dosimeter Response to Accelerator Beams of $0.5,1.9$, and $5.0 \mathrm{MeV}$. Note the change in dosimeter response with energy.

\begin{tabular}{|c|c|c|c|c|c|c|c|c|}
\hline \multicolumn{2}{|c|}{ Contractor } & $50 \mathrm{MF}$ & $\begin{array}{l}\text { Me: } \\
10 \mathrm{MF}\end{array}$ & 501.9 & $\begin{array}{l}\text { MeV } \\
100 \mathrm{MF}\end{array}$ & $50 \mathrm{MF}$ & $\begin{array}{l}5.0 \mathrm{MeV} \\
10 \mathrm{MF}\end{array}$ & 200 सF: \\
\hline$\vec{A}$ & $\begin{array}{l}\text { MEAN } \\
\text { SD }\end{array}$ & $\begin{array}{r}117.7 \\
30.2\end{array}$ & $\begin{array}{r}227.4 \\
21.0\end{array}$ & $\begin{array}{l}35.9 \\
24.6\end{array}$ & $\begin{array}{r}155.0 \\
15.0\end{array}$ & $\begin{array}{l}51.0 \\
57.5\end{array}$ & $\begin{array}{r}100.2 \\
55.6\end{array}$ & $\begin{array}{r}4.5 \\
3.5\end{array}$ \\
\hline$E$ & $\begin{array}{c}\text { MEAN } \\
\text { SD }\end{array}$ & $\begin{array}{r}5.6 \\
5.6\end{array}$ & $\begin{array}{r}115.2 \\
0.1\end{array}$ & $\begin{array}{l}41.4 \\
1.5 .9\end{array}$ & $\begin{array}{r}102.2 \\
20.5\end{array}$ & 0.0 & 0.0 & $\begin{array}{r}3.2 \\
-.8\end{array}$ \\
\hline$E$ & $\begin{array}{l}\text { MEAN } \\
\text { SD }\end{array}$ & $\begin{array}{r}104.9 \\
7.5\end{array}$ & $\begin{array}{r}206.6 \\
19.0\end{array}$ & $\begin{array}{l}7.3 .6 \\
8.6\end{array}$ & $\begin{array}{r}146.0 \\
10.2\end{array}$ & $\begin{array}{r}25.3 \\
9.0\end{array}$ & $\begin{array}{r}46.8 \\
6.2\end{array}$ & $\begin{array}{r}49.2 \\
2.5\end{array}$ \\
\hline$D$ & $\begin{array}{l}\text { MEAN } \\
\text { SD }\end{array}$ & $\begin{array}{r}114.4 \\
26.5\end{array}$ & $\begin{array}{r}220.0 \\
22.0\end{array}$ & $\begin{array}{l}79.2 \\
14.3\end{array}$ & $\begin{array}{r}202.4 \\
50.2\end{array}$ & $\begin{array}{l}50.0 \\
12.5\end{array}$ & $\begin{array}{l}79.2 \\
12.0\end{array}$ & $\begin{array}{l}19.8 \\
12.0\end{array}$ \\
\hline$E$ & $\begin{array}{l}\text { MEAN } \\
\text { SD }\end{array}$ & $\begin{array}{l}55.6 \\
29.5\end{array}$ & $\begin{array}{l}91.4 \\
58.4\end{array}$ & $\begin{array}{l}57.8 \\
22.6\end{array}$ & $\begin{array}{l}77.4 \\
5.0\end{array}$ & $\begin{array}{r}17.7 \\
4.1\end{array}$ & $\begin{array}{l}32.2 \\
11.3\end{array}$ & $\begin{array}{l}21.6 \\
17.5\end{array}$ \\
\hline$F$ & $\begin{array}{l}\text { MEAN } \\
\text { SD }\end{array}$ & $\begin{array}{r}78.0 \\
9.7\end{array}$ & $\begin{array}{r}139.4 \\
13.2\end{array}$ & $\begin{array}{r}58.8 \\
8.0\end{array}$ & $\begin{array}{r}120.0 \\
21.6\end{array}$ & $\begin{array}{r}1.5 .4 \\
8.5\end{array}$ & $\begin{array}{r}7.2 \\
3.9\end{array}$ & $\begin{array}{r}27.9 \\
4.4\end{array}$ \\
\hline$G$ & $\begin{array}{l}\text { MEAN } \\
\text { SD }\end{array}$ & $\begin{array}{r}101.8 \\
18.7\end{array}$ & $\begin{array}{r}123.6 \\
49.0\end{array}$ & $\begin{array}{l}97.0 \\
15.5\end{array}$ & $\begin{array}{r}15.3 .3 \\
26.4\end{array}$ & $\begin{array}{r}5.8 \\
8.5\end{array}$ & $\begin{array}{r}54.9 \\
6.6\end{array}$ & $\begin{array}{r}4.5 .0 \\
6.2\end{array}$ \\
\hline$H$ & $\begin{array}{l}\text { MEAN } \\
\text { SD }\end{array}$ & $\begin{array}{l}62.0 \\
53.5\end{array}$ & $\begin{array}{l}215.2 \\
104 .\end{array}$ & $\begin{array}{r}124.1 \\
12.8\end{array}$ & $\begin{array}{r}149.2 \\
4.3 .1\end{array}$ & $\begin{array}{l}39.6 \\
53.9\end{array}$ & $\begin{array}{l}19.8 \\
57.3\end{array}$ & $\begin{array}{l}91.1 \\
95.2\end{array}$ \\
\hline I & $\begin{array}{l}\text { MEAN } \\
\text { SD }\end{array}$ & - & -- & -- & - & -- & -- & - \\
\hline $\mathrm{J}$ & $\begin{array}{l}\text { MEAN } \\
\text { SD }\end{array}$ & $\begin{array}{r}25.1 \\
6.9\end{array}$ & $\begin{array}{r}44.5 \\
7.4\end{array}$ & - & -- & $\begin{array}{l}4.2 \\
2.2\end{array}$ & $\begin{array}{r}-5.2 \\
5.9\end{array}$ & $\begin{array}{r}13.5 \\
4.7\end{array}$ \\
\hline$\varepsilon$ & $\begin{array}{l}\text { MEAN } \\
\text { SD }\end{array}$ & $\begin{array}{r}1.9 .8 \\
4.4\end{array}$ & $\begin{array}{r}172.4 \\
29.4\end{array}$ & $\begin{array}{r}99.6 \\
6.6\end{array}$ & $\begin{array}{r}174.0 \\
16.9\end{array}$ & $\begin{array}{l}5.2 \\
16.7\end{array}$ & $\begin{array}{r}55.5 \\
6.0\end{array}$ & $\begin{array}{r}115.2 \\
50.4\end{array}$ \\
\hline L & $\begin{array}{l}\text { MEAN } \\
\text { SD }\end{array}$ & $\begin{array}{r}121.6 \\
44.1\end{array}$ & $\begin{array}{r}260.2 \\
75.9\end{array}$ & $\begin{array}{l}45.2 \\
25.2\end{array}$ & $\begin{array}{r}119.2 \\
34.1\end{array}$ & $\begin{array}{c}204.4 \\
194 .\end{array}$ & $\begin{array}{c}203.2 \\
112 .\end{array}$ & $\begin{array}{r}134.0 \\
55.1\end{array}$ \\
\hline TOTAL & MEAN & 38.9 & 169.6 & 75.2 & 139.9 & 43.3 & 56.4 & 54.5 \\
\hline
\end{tabular}


TABLE A.21. Accuracy of neutron dosimeters irradiated by accelerator beams of $0.5,1.9$, and $5.0 \mathrm{MeV}$. Note the energy dependence of neutron dosimeter response.

\begin{tabular}{|c|c|c|c|c|c|c|c|}
\hline Contractor & so $\mathrm{MR}$ & $\begin{array}{l}\text { MeV } \\
100 \mathrm{MP}\end{array}$ & 50 MF! & $\begin{array}{l}\text { MeV } \\
100 \mathrm{MR}\end{array}$ & $50 \mathrm{MR}$ & $\begin{array}{l}5.0 \mathrm{MEV} \\
100 \mathrm{MF}\end{array}$ & $200 \mathrm{MF}$ \\
\hline$--\infty---\infty--\infty$ & ----- & ---- & ----- & $--\infty-$ & ----- & $-\cdots-\infty$ & ---- \\
\hline A & 1.92 & 1.82 & .92 & .75 & -.24 & -.10 & -.74 \\
\hline$B$ & .41 & .45 & -.08 & .14 & -- & -- & -.82 \\
\hline c & 1.5 & 1.55 & . & .54 & -.50 & -.50 & -.75 \\
\hline D & 1.84 & 1.75 & .77 & 1.26 & .08 & -.16 & -.90 \\
\hline$E$ & .58 & .14 & .09 & -.24 & -.79 & -.74 & -.88 \\
\hline$F$ & .93 & 1.35 & .24 & .30 & -.88 & -.72 & -.85 \\
\hline G & 1.55 & .54 & .94 & .72 & -.15 & -.42 & -.76 \\
\hline $\mathrm{H}$ & .21 & 1.51 & 1.18 & .37 & -.30 & -.86 & -.59 \\
\hline I & -- & -- & - & - & - & - & -- \\
\hline$J$ &.- .38 & -.45 & -- & - & -.88 & -1.04 & -.93 \\
\hline$\kappa$ & 1.96 & .89 & -1.60 & -.46 &.- .37 & -.44 & -.49 \\
\hline$L$ & 1.09 & 1.77 & -.56 & .05 & .15 & -.43 & -.49 \\
\hline TOTAL & 1.04 & 1.02 & .25 & .35 & -.59 & -.54 & -.74 \\
\hline
\end{tabular}


TABLE A.22. Mean and Standard Deviation Summary of Neutron Dosimeter Response to reactor beams of various energies $(25 \mathrm{keV}, 2.0 \mathrm{keV}$, and thermal neutrons).

\begin{tabular}{|c|c|c|c|c|c|c|}
\hline & & & 25 & & $2.0 \mathrm{kEU}$ & Therma 1 \\
\hline Contr $\equiv$ & tor & CONTFIOL & $50 \mathrm{MF}$ & $100 \mathrm{MF}$ & $25 \mathrm{MF}$ & $25 \mathrm{MF}$ \\
\hline A & $\begin{array}{l}\text { MEAN } \\
\text { SD }\end{array}$ & 89.0 & $\begin{array}{l}2891 . \\
15.8 .\end{array}$ & $\begin{array}{l}6925 . \\
1956 .\end{array}$ & $\begin{array}{l}5649 . \\
1087 .\end{array}$ & $\begin{array}{l}162.8 \\
260 .\end{array}$ \\
\hline$E$ & $\begin{array}{l}\text { MESAN } \\
\text { SD }\end{array}$ & 25.0 & $\begin{array}{rl}2 & 269 . \\
56.7\end{array}$ & $\begin{array}{r}4406 . \\
238 .\end{array}$ & $\begin{array}{r}3162 . \\
255 .\end{array}$ & $\begin{array}{r}3440 . \\
319 .\end{array}$ \\
\hline C & $\begin{array}{l}\text { MEAN } \\
\text { SD }\end{array}$ & $7 \star .9$ & $\begin{array}{r}1726 . \\
189 .\end{array}$ & $\begin{array}{l}5204 . \\
312 .\end{array}$ & $\begin{array}{r}2275 . \\
144 .\end{array}$ & $\begin{array}{r}4511 . \\
535 .\end{array}$ \\
\hline D & $\begin{array}{l}\text { MEAN } \\
\text { SD }\end{array}$ & 0.0 & $\begin{array}{r}4472 . \\
297 .\end{array}$ & $\begin{array}{r}9514 . \\
529 .\end{array}$ & $\begin{array}{r}5328 . \\
456 .\end{array}$ & 0.0 \\
\hline$\varepsilon$ & $\begin{array}{l}\text { MEAN } \\
\text { SD }\end{array}$ & 22.9 & $\begin{array}{l}911 . \\
192 .\end{array}$ & $\begin{array}{r}1201 . \\
637 .\end{array}$ & $\begin{array}{l}364 . \\
395 .\end{array}$ & $\begin{array}{r}-3 \pm 7 . \\
401 .\end{array}$ \\
\hline$F$ & $\begin{array}{l}\text { MEAN } \\
\text { SD }\end{array}$ & 10.0 & $\begin{array}{r}1473 \\
291\end{array}$ & $\begin{array}{r}4084 . \\
430 .\end{array}$ & $\begin{array}{r}2225 . \\
206 .\end{array}$ & $\begin{array}{r}4850 . \\
51.4\end{array}$ \\
\hline$G$ & $\begin{array}{l}\text { MEAN } \\
\text { SD }\end{array}$ & 0.0 & $\begin{array}{l}451 . \\
284 .\end{array}$ & $\begin{array}{l}439 . \\
368 .\end{array}$ & $\begin{array}{l}555 . \\
303 .\end{array}$ & $\begin{array}{l}471 . \\
344 .\end{array}$ \\
\hline $\mathrm{H}$ & $\begin{array}{c}\text { MEAN } \\
\text { SD }\end{array}$ & 119. & $\begin{array}{r}1687 . \\
175 .\end{array}$ & $\begin{array}{r}3647 . \\
466 .\end{array}$ & $\begin{array}{r}2099 . \\
230 .\end{array}$ & $\begin{array}{r}12090 \\
855\end{array}$ \\
\hline I & $\begin{array}{l}\text { MEAN } \\
\text { SD }\end{array}$ & -- & -- & - & - & -- \\
\hline $\mathrm{J}$ & $\begin{array}{l}\text { MEAN } \\
\text { SD }\end{array}$ & 3.8 & $\begin{array}{l}557 . \\
57.1\end{array}$ & $\begin{array}{r}1075 . \\
124 .\end{array}$ & $\begin{array}{l}649 . \\
68.1\end{array}$ & $\begin{array}{l}76.4 \\
35.5\end{array}$ \\
\hline$k$ & $\begin{array}{l}\text { MEAN } \\
\text { SD }\end{array}$ & 106. & $\begin{array}{r}1756.0 \\
79.0\end{array}$ & $\begin{array}{r}3442 . \\
162 .\end{array}$ & $\begin{array}{r}2365 . \\
106 .\end{array}$ & $\begin{array}{c}858 \overrightarrow{3} . \\
437 .\end{array}$ \\
\hline$L$ & $\begin{array}{c}\text { MEAN } \\
\text { SD }\end{array}$ & -99.7 & $\begin{array}{r}5275 . \\
148 .\end{array}$ & $\begin{array}{r}6592 . \\
14.5 .\end{array}$ & $\begin{array}{r}4969 . \\
192 .\end{array}$ & $\begin{array}{l}140 . \\
197 .\end{array}$ \\
\hline TOTAL & MEAN & 22.1 & 1945. & 3957. & 2784. & 2694 . \\
\hline
\end{tabular}


TABLE A.23. Accuracy of Neutron Dosimeters Irradiated by Reactors Beams of Various Energies. Note the large over-response of dosimeters calibrated to unmoderated Californium to these low energy fields.

\begin{tabular}{|c|c|c|c|c|}
\hline & \multicolumn{2}{|c|}{$25 \mathrm{keV}$} & $2.0 \mathrm{req}$ & Thermal \\
\hline Contractor & $50 \mathrm{MF}$ & $100 \mathrm{MF}$ & $25 \mathrm{MF}$ & $25 \mathrm{MR}$ \\
\hline A & 55.0 & 67.4 & 221. & 2.0 \\
\hline $\mathrm{E}$ & 45.9 & 42.8 & 124. & 136. \\
\hline c & 32.0 & 30.5 & 35.9 & 176. \\
\hline D & 89.4 & 84.1 & 232 & - \\
\hline$E$ & 14.8 & 10.8 & 32.6 & -15.4 \\
\hline $\mathbf{F}$ & 28.4 & 39.7 & 87.6 & 19.0 \\
\hline $\mathbf{G}$ & 8.0 & 3.4 & 20.4 & 18.6 \\
\hline $\mathrm{H}$ & 30.4 & 34.5 & 78.2 & 478. \\
\hline I & - & - & -- & -- \\
\hline $\mathrm{J}$ & 10.1 & 9.7 & 24.8 & 1.9 \\
\hline$k$ & 32.0 & 32.4 & 89.5 & 388 \\
\hline L & 56.5 & 65.9 & 202. & 8.6 \\
\hline TQTAL & 37.2 & 38.2 & 109. & 116. \\
\hline
\end{tabular}




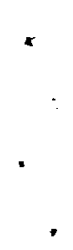




\section{DISTRIBUTION}

No. of

Copies

OFFSITE

5 E. J. Vallario

Senior Health Physicist

DOE Division of Operation and

Environmental Safety

Washington, DC 20545

27 DOE Technical Information Center

R. E. Alexander

Pantex Plant

P.0. Box 30020

Amari110, TX 79177

J. R. Cortez

Los Alamos National Laboratory

Box 1663, MS 692

Los Alamos, NM 87545

S. L. Crain

Monsanto Research

Mound Facility

Miamisburg, $\mathrm{OH} 45432$

J. P. Cusimano

RESL-CF-690

U.S. Department of Energy

550 Second Street

Idaho Fal1s, ID 83401

E. H. Dolecek

Argonne National Laboratory

OHS/HP Bldg. 14

9700 S. Cass Avenue

Argonne, IL 60439

J. H. Elliott

Lawrence Livermore National Laboratory

P.0. Box $5505 \quad L-383$

Livermore, CA 94550
No. of

Copies

R. B. Falk

Rockwell International

Rocky Flats Plant

P. 0. Box 464

Golden, CO 80401

R. M. Hall

735-A

Savannah River Plant

E. I. DuPont deNemours \& Company Aiken, SC 29801

J. H. P. Lawrence

Group $H-1$, MS-401

Los Alamos National Laboratory

Los Alamos, NM 87545

L. Phillips

Brookhaven National Laboratory

B1dg. 535A

Upton, NY 11973

T. J. Powel1

Lawrence Livermore National Laboratory

P.0. Box $5505 \quad L-383$

Livermore, CA 94550

D. J. Thompson

Radiation Dosimetry

Division 3313

Sandia National Laboratories

P. 0. Box 5800

Albuquerque, NM 87185

R. B. Schwartz

Bldg. 235

National Bureau of Standards

Washington, DC 20234

B. P. Smith

Reynolds Electric \& Engineering Co., Inc.

P.0. Box 14400 MS-708

Las Vegas, NV 89114 
No. of

Copies

E. Storm

Los Alamos National Laboratory

Box 1663 MS-692

Los Alamos, NM 87545

C. Swezey

Brookhaven National Laboratory

B1dg. 535A

Upton, NY 11973

I. J. Wel1s

Reynolds Electric \& Engineering Co., Inc.

P.0. Box 14400 MS-708

Las Vegas, NV 89114

R. C. Yoder

R. S. Landuer, Jr., \& Company

Glenwood Science Park

Glenwood, IL 60425

\section{ONSITE}

DOE Richland Operations Office

H. E. Ransom/ P. K. Clark
No. of

Copies

60 Pacific Northwest Laboratory

W. J. Bair

L. W. Brackenbush

F. N. Eichner

G. W. R. Endres

T. H. Essig

L. G. Faust

J. J. Fix

R. A. Fox

W. A. Glass

R. T. Hadley

D. E. Hadlock

G. R. Hoenes

R. T. Hogan

C. D. Hooker

J. C. McDona ld (25)

J. L. Pappin

P. L. Roberson

J. M. Selby

Technical Information (5)

Publishing Coordination (2) 